\title{
Article
}

\section{The Birth of an Academic Obsession: The History of the Countermajoritarian Difficulty, Part Five}

\author{
Barry Friedman $\dagger$
}

\section{CONTENTS}

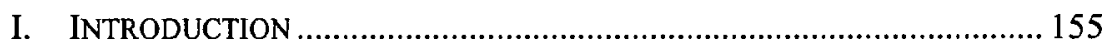

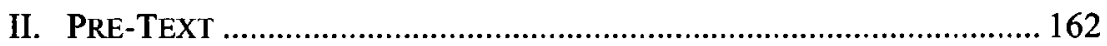

$\dagger$ Professor of Law, New York University School of Law. A.B., 1978, University of Chicago; J.D., 1982, Georgetown University. My deep thanks to the many colleagues who offered assistance with this project by reading an earlier draft or discussing these ideas at length with me: Jill Anton, Rachel Barkow, Yochai Benkler, Rebecca Brown, Jesse Choper, Anastasia Crosswhite, Michael Dorf, Norman Dorsen, Christopher Eisgruber, Richard Fallon, Dan Farber, Stephen Feldman, Phil Frickey, Howard Gillman, Mark Graber, Stephen Griffin, Laura Kalman, Michael Klarman, Larry Kramer, Kurt Lash, Daryl Levinson, Ken Murchison, William Nelson, Rick Pildes, Ed Purcell, Gary Rowe, Larry Sager, Michael Seidman, Suzanna Sherry, Jeannie Suk, Dalia Tsuk, Mark Tushnet, Kenneth Ward, and Nick Zeppos. The paper was improved by comments received at a Vanderbilt Law School faculty workshop, a New York University Legal History Colloquium, a University of Texas faculty workshop, a panel at the Law and Society Association Annual Meeting, and a panel at the American Political Science Association Annual Meeting. I'm especially grateful to my editors at The Yale Law Journal for a set of extremely helpful comments. My research assistants, Melissa Aoyagi, Stacey Brandenberg, Anastasia Crosswhite, Stacy Feld, Jeremy Saks, and Christina Sanford offered invaluable assistance, as did Lisa Mihajlovic. This project could not have happened without the extraordinary reference librarians at the Vanderbilt Law School and NYU School of Law libraries. I am grateful for the financial support of the Filomen D'Agostino and Max E. Greenberg Research Fund. This whole project was cooked up while at the Rockefeller Foundation Study Center in Bellagio, Italy. 


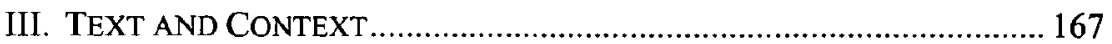

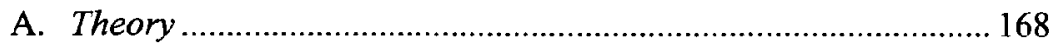

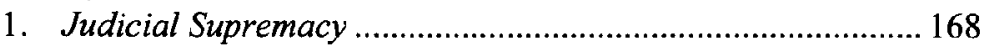

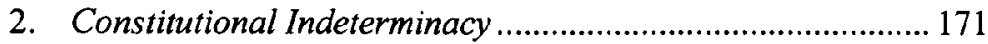

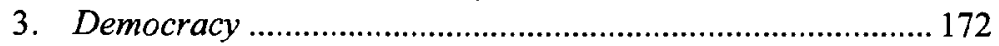

4. The Court's Work (and the Idea of the Majority)................... 173

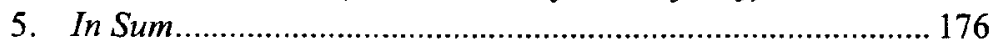

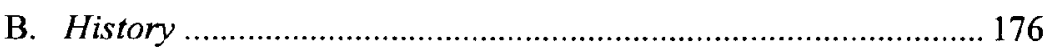

1. 1939-1951: The Lull ... and the Seeds .............................. 176

a. The Court Does Little and Garners Little Reaction........ 176

b. Nonetheless, Academics Fret ......................................... 181

2. Brown v. Board of Education: 1954................................... 185

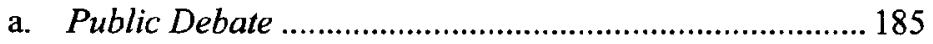

b. Academic Silence .............................................................. 191

3. The "Communist" Decisions: 1957 ..................................... 193

a. The Court in Trouble ..................................................... 193

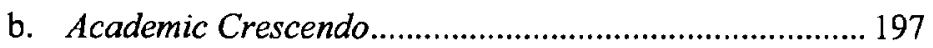

4. Bickel, the "Counter-Majoritarian Difficulty,"

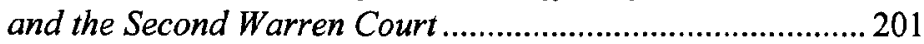

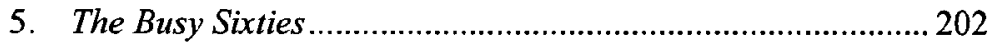

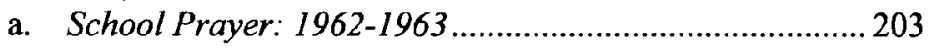

b. Reapportionment: 1962-1969 …..................................... 206

c. The Rights of Criminal Suspects .................................... 210

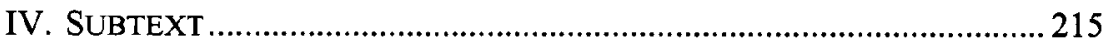

A. The Long Shadow of the Progressive Era.................................. 217

1. The Problem with the Countermajoritarian Problem at Mid-Century .................................................. 218

2. The Lingering Odor of the Realist Critique .......................... 222

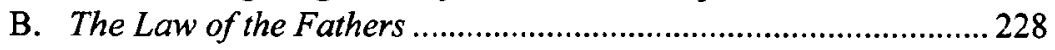

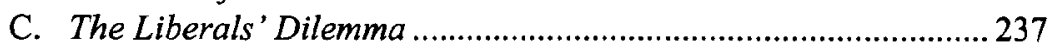

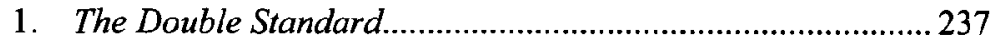

2. Unsuccessful Attempts To Explain the Judicial Role ............. 241

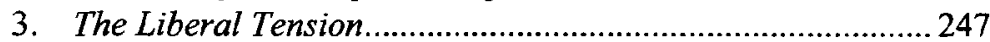

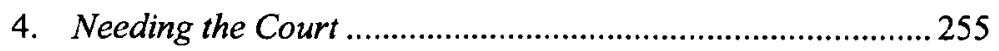

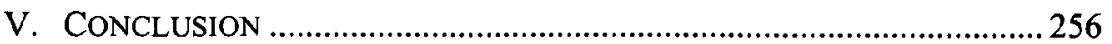

Imaged with the Permission of Yale Law Journal 


\section{INTRODUCTION}

The "democracy" issue is a mirage; we are led back around to the question on its merits.'

Sit tight, the worm is about to turn again in constitutional "theory." Fed up with the activism of the Rehnquist Court, academics are coming to see the central obsession of constitutional theory in an entirely new light. Before, the central obsession was the inconsistency between judicial review and democracy. Now, it is the inconsistency between judicial review and democracy.

If this seems confusing, it ought to. For decades, legal academics have struggled with the "countermajoritarian difficulty": the problem of justifying the exercise of judicial review by unelected and ostensibly unaccountable judges in what we otherwise deem to be a political democracy. This was a largely liberal academy raised on the legacy of the Warren Court and hopeful that those days of judicial liberalism would return. $^{2}$ But after Bush v. Gore ${ }^{3}$ and numerous recent Supreme Court decisions striking down progressive congressional legislation, ${ }^{4}$ liberal academics are finally getting the message: The Supreme Court is not their friend and is not likely to be anytime soon. This has led to a spate of articles decrying the inconsistency of democracy with judicial review, and calling for constitutional interpretation outside the courts. ${ }^{5}$

1. Charles L. Black, JR., THe PeOPle and the CourT 181 (1960).

2. For the story, see generally Laura Kalman, THE Strange Career of Legal LIBERALISM (1996).

3. 531 U.S. 98 (2000).

4. E.g., Bd. of Trs. of Univ. of Ala. v. Garrett, 531 U.S. 356 (2001) (striking down a provision of the Americans with Disabilities Act that imposed monetary liability on states); United States v. Morrison, 529 U.S. 598 (2000) (striking down the civil damages remedy of the Violence Against Women Act); Kimel v. Fla. Bd. of Regents, 528 U.S. 62 (2000) (striking down a provision of the Age Discrimination in Employment Act imposing monetary liability on states); Alden v. Maine, 527 U.S. 706 (1999) (barring Fair Labor Standards Act claims against nonconsenting states in state courts).

5. See, e.g., MARK TUShNET, TAKING the CONSTITUTION AWAY fRom the COURTS 194 (1999) (arguing for a "populist constitutional law" where "the public generally should participate in shaping constitutional law more directly ... [and] reclaim [the Constitution] from the courts"); Rachel E. Barkow, More Supreme than Court? The Fall of the Political Question Doctrine and the Rise of Judicial Supremacy, 102 COLUM. L. REV. 237 (2002) (ruing the extent of judicial supremacy vis-à-vis coordinate branches, and calling for the revival of the classical political question doctrine to enhance the ability of other branches to say what the law is); Larry D. Kramer, The Supreme Court, 2000 Term-Foreword: We the Court, 115 HARV. L. REv. 4, 15-16 (2001) (arguing for a stronger, coequal role for the executive and legislative branches of government, acting as agents of the people, to interpret and implement the Constitution); Robert C. Post \& Reva B. Siegel, Equal Protection by Law: Federal Antidiscrimination Legislation After Morrison and Kimel, 110 YALE L.J. 441, 444 (2000) (analyzing recent Supreme Court decisions invalidating congressional statutes enacted under the Commerce Clause or Section 5 and "question[ing] the court-centered model of constitutional interpretation that these decisions assume [by] examining the relationship between Court and Congress" and "argu[ing] that this 
Matters should now be clearer. Before, judicial review was good-so long as it was used properly. Now, judicial review is bad. The curious thing, of course, is that under either scenario, scholars see a countermajoritarian problem; under either formulation, they describe an inconsistency between judicial review and democracy that needs to be addressed. It is simply that now-in response to the Supreme Court's present agenda - a project of justification has turned to one of critique.

In fairness, if the "theory" of liberal scholarship sometimes seems overly driven by a desire for preferred outcomes, conservative scholars are prone to the same problem. What, after all, were conservatives ever doing complaining about judicial activism? Conservatives have (almost) always loved the courts, and rarely loved the people. Of course, they've almost always had the courts, and usually not the people. ${ }^{6}$ But beginning in the 1960 s - especially after the Supreme Court began to protect privacy in the realm of personal morality-conservatives also began to question how judicial review was defensible in a democracy. ${ }^{7}$ Now that things are going really well for them in the courts, all of a sudden conservatives are going to need their own "theory" to justify countermajoritarian judicial review. ${ }^{8}$

There is a critical need for constitutional theory that is not simply a response to the last five or ten years of Supreme Court decisions, but this will not become a sustained project of constitutional scholars until we confront ourselves with the historical contingency of our understandings about judicial review. That is the point of this Article: to historicize the problem of judicial review so that we can see that the countermajoritarian difficulty that obsesses the legal academy is not some timeless problem grounded in immutable truths. ${ }^{9}$ Rather, it represents—as it almost always

history justifies a continuing role for democratic vindication of equality values"). Recent academic conferences also reflect this trend. See The Assault of Federalism: Developing New Strategies To Protect Civil Rights in a Conservative Era, Conference at Harvard Law School (Apr. 2002); Congressional Power in the Shadow of the Rehnquist Court, Conference at Indiana Law School (Feb. 2002).

6. See, e.g., Barry Friedman, The History of the Countermajoritarian Difficulty, Part Three: The Lessan of Lochner, 76 N.Y.U. L. REV. 1383 (2001) (describing popular attacks on the conservative judiciary from 1895 to 1924 ).

7. See infra text accompanying notes 463-464 (discussing Robert Bork's 1968 Fortune attack on judicial review).

8. Like liberals, they are also going to have to work around their own theoretical explanations of why constitutional interpretation should not be juriscentric. See, e.g., John Harrison, The Role of the Legislative and Executive Branches in Interpreting the Constitution, 73 CORNELL L. REV. 371 (1988); Michael Stokes Paulsen, The Most Dangerous Branch: Executive Power To Say What the Law Is, 83 GEO. L.J. 217 (1994). Of course, the greatest irony would be if liberals and conservatives united in this attack on judicial supremacy.

9. See Stephen M. Griffin, What Is Constitutional Theory? The Newer Theory and the Decline of the Learned Tradition, 62 S. CAL. L. REV. 493, 506 (1980) (observing that the countermajoritarian problem has set the terms of the debate for twenty-five years and asserting that " $[\mathrm{t}] \mathrm{his}$ kind of stability in scholarly inquiry signals either that the debate concerns an issue of fundamental importance or that something is seriously wrong"). 
has-a need to justify present-day political preferences in light of an inherited intellectual tradition. Seen in that light, the academy ought to be able to free itself from the rhetorical grasp of the countermajoritarian difficulty and devote itself to a constitutional theory that is less immediately political, and more enduring.

This claim undoubtedly calls for immediate clarification; one can hear the clamor of the doubters already. How could the countermajoritarian problem be historically contingent? If not a "timeless, immutable truth," is there not at least a very real theoretical problem embedded in the fabric of American constitutionalism? American government is democratic; Supreme Court Justices are unelected and unaccountable. Whatever the worth of the institution of judicial review as a historical and philosophical matter, the countermajoritarian problem is one we are and always have been stuck with. Right?

Not so, or not entirely so. In order to consider the possibility that the paradigm that has driven constitutional theory for more than half a century may be neither necessary nor accurate, it is essential at the outset to distinguish the claim made here from two other possible claims with which it might be confused. One, the historical claim, is false. The other, the philosophical claim, is correct, but (for better or for worse) has very little to do with the project of most constitutional theorists.

As a historical matter, it is not true that the countermajoritarian problem that obsesses constitutional scholarship has been with us always. It is true that judicial review has been criticized on and off since at least 1800 on the ground that it interferes with popular will. ${ }^{10}$ But it is important to distinguish a criticism that is leveled at courts on the occasions when circumstance seems to warrant it from the intellectual problem of justifying judicial review that has gripped the academy nonstop since the early 1940s. In truth, although the criticism of constitutional judges as unaccountable was leveled as early as 1800 , it was not prevalent for the next roughly one hundred years, largely because concepts of judicial supremacy were not extant through that period, and thus there was no particular problem of unaccountable judges trumping popular will. Political actors during the Jacksonian era defied the Supreme Court; ${ }^{11}$ during Reconstruction they threatened its existence. ${ }^{12}$ Thus, there was not much of a countermajoritarian problem. It was only during the Populist-Progressive Era, when it made abundant sense, that the countermajoritarian problem

10. See Barry Friedman, The History of the Countermajoritarian Difficulty, Part One: The Road to Judicial Supremacy, 73 N.Y.U. L. REV. 333 (1998).

11. See id. at 398-401.

12. See Barry Friedman, The History of the Countermajoritarian Difficulty, Part Two: Reconstruction's Political Court (2001) (unpublished manuscript, on file with author). 
found full voice in public debates. ${ }^{13}$ Then too, however, it was an entirely apt criticism of what courts were doing, not the basis for theorizing to justify judicial review.

We will see that academic fixation with the countermajoritarian problem differs significantly from popular criticism of the courts that appears as circumstances warrant. That the two diverge is quite evident from a comparison of academic and popular reaction to two of the Warren Court's most noteworthy projects. The Supreme Court's reapportionment decisions in the 1960s were met with great public support and approval, but the academic tradition discussed here criticized them specifically on the ground that it was inappropriate for judges to trump popular will. ${ }^{14}$ Conversely, by the time of the decision in Miranda v. Arizona, the Supreme Court's criminal procedure decisions were under broad popular attack on the grounds that they interfered with popular preferences, but the academic tradition approved those decisions. ${ }^{15}$ Whatever was going on in the academy-and it is the task of this Article to examine just that-academic thinking was not congruent with, or even necessarily related to, the charge leveled in public debate at predictable times that the judges were trumping, popular will. And it is in this disjuncture between public opinion and academic concern that we can see the countermajoritarian problem for what it is-an obsession that grips the academy even when it fails to describe reality.

On the other hand, there is an interesting question of political theory concerning how judicial review fits into the fabric of majoritarian democracy, but-as the next Part explains-this is not what most constitutional theorists address either. The theorist truly devoted to problems of democratic theory would want to examine each and every institution of democratic governance on this basis, from the least representative-such as the Federal Reserve Board, or independent administrative agencies, or the Senate for that matter-to the seemingly most representative, such as the House of Representatives. Constitutional theorists rarely address these institutions or devote any sustained attention to the real questions of political theory they present, once again demonstrating that academics are not focused on an enduring problem of political theory. Rather, the academic tradition examined here is courtobsessed. Judges are the problem, end of story. Or, more accurately, beginning of story, for commonly the countermajoritarian problem is but a frame for constitutional theorists, a jumping-off point for them to argue,

13. See Friedman, supra note 6 .

14. See infra Subsection III.B.5.b.

15. See infra Subsection III.B.5.c. 
mostly as a matter of personal preference, how constitutional cases should be decided.

The academic obsession with the countermajoritarian problem has been with us for a long time, obscuring the ability of constitutional scholars to see judicial review for what it is. In 1962, Alexander Bickel wrote The Least Dangerous Branch. ${ }^{16}$ What everyone recalls about the book is Bickel's stunning attack on the legitimacy of judicial review. But what if the problem Bickel (and the generation that preceded him) handed down to us was not an ageless theoretical problem, stubbornly resistant to solution, but a matter of immediate constitutional politics dressed up as theory? Too easily forgotten is the fact that unlike most criticism of courts throughout history as interfering with popular will, The Least Dangerous Branch was a defense of judicial review, one especially attuned to the circumstances of the time in which Bickel wrote. What if Bickel simply was arguing for, and trying to justify, a set of jurisprudential outcomes he favored personally, within the limits of an intellectual structure handed down to him by his teachers? And what if today's scholars are simply doing the same?

History can help us to see this. The task here is to recreate the academic world in the mid-twentieth century, so we can see where the modern obsession with the countermajoritarian problem was born. ${ }^{17}$ The thesis of this Article is that the countermajoritarian problem came to grip the legal academy as a result of historical, professional, and intellectual forces that, as a cultural matter, simply were unavoidable for many academics (even though they seemed to matter little to those beyond the professorate). These forces can be grouped together into roughly three problems.

First, the countermajoritarian difficulty that has preoccupied academics really is a deeply felt dilemma unique to political liberals, one that became salient when for the first, and perhaps only, time in history the Supreme Court-under the leadership of Earl Warren-took on a liberal cast. ${ }^{18}$ For much of its history (and particularly since the beginning of the twentieth century) the Court's attackers have been liberal, the defenders conservative. ${ }^{19}$ On those occasions when liberals attacked judges for

16. AleXANDER M. BICKEL, THE LEAST DANGEROUS BRANCH (1962).

17. Despite widespread recognition that it is problematic, this issue has received remarkably little attention. Some work, however, is closely related. In two Harvard Forewords, Erwin Chemerinsky and Morton Horwitz provide excellent accounts of how democracy became a central norm in constitutional law. See Erwin Chemerinsky, The Supreme Court, 1988 Term-Foreword: The Vanishing Constitution, 103 HaRV. L. REV. 43, 71 (1989); Morton J. Horwitz, The Supreme Court, 1992 Term-Foreword: The Constitution of Change: Legal Fundamentality Without Fundamentalism, 107 HARV. L. REV. 30, 63 (1993). Laura Kalman's The Strange Career of Legal Liberalism, supra note 2, provides an engaging account of the emergence of a crisis in the legal academy over the indeterminacy of constitutional norms.

18. See infra Section IV.C (developing this argument).

19. "Liberals," both here and throughout, refers generally to those who see the utility of judicial review in protecting noneconomic individual liberties (think, for example, of procreative rights) and racial equality, but not economic rights (or, at the moment, federalism). 
interfering with popular will, conservative defenders responded that the role of courts was to serve as a check on democracy. ${ }^{20}$ When the tables turned in the 1950s and 1960s, however, liberals were hoisted on their own petard. How could they approve of the results of Warren Court decisions, while still retaining what they claimed was a longstanding commitment to democratic government and disapproval of judicial review as inconsistent with it? The countermajoritarian difficulty as we know it today is primarily a product of liberal anxiety at mid-century to reconcile what seemed to them an intractable tension in their own way of thinking.

The internal tension experienced by Bickel's generation is palpable once one sees the peculiarity of it. After all, as an accurate description of American constitutionalism at mid-century, just as is the case today, the countermajoritarian critique was woefully lacking. ${ }^{21}$ More important, there was a theoretical solution to the problem of the shifting liberal views toward judicial review that many scholars of the time found intuitively appealing. It was found in the famous footnote four of the Carolene Products decision. That footnote suggested the role of heightened judicial scrutiny was to safeguard specifically enumerated rights, protect minorities, and correct failures of the political process. Particularly in the period before Bickel crystallized the countermajoritarian difficulty, Carolene's "process theory" seemed to have broad appeal to many as a justification for more aggressive judicial review. ${ }^{22}$

But-and here is the second problem-Bickel and his contemporaries could not escape the countermajoritarian problem as a description of judicial review, because it had been inculcated in them by their most beloved teachers-iconic figures, themselves trapped in an old way of thinking, yet anxious to maintain and perpetuate their hegemony. The formulation of the problem of judicial review as inconsistent with democracy was not Bickel's, but was the intellectual tradition of figures such as James Bradley Thayer, Learned Hand, Felix Frankfurter, and perhaps Oliver Wendell Holmes and Louis Brandeis as well. Their

"Conservatives," on the other hand, have preferred that judges protect economic rights and defend the values of federalism. These are sweeping caricatures, of course, but they do capture familiar perspectives on the rule of constitutional judging. And as the Court's own agenda shifts, conservative and liberal views about constitutional judging shift as well. Thus, when the Court was protecting conservative values at the turn of the last century, liberals attacked the institution of judicial review. When the Court changed direction after 1937, liberal views on judicial review changed too. The Court of late has been advancing the conservative perspective rather aggressively-hence newfound liberal discontent with judicial review.

20. This was exacerbated by the death of legal formalism and widespread acknowledgment that judges imposed their own values when interpreting the Constitution. Especially in light of constitutional indeterminacy, what justified the exercise of judicial review to further values they preferred?

21. See infra Subsection IV.A.1.

22. See infra notes 320-330 and accompanying text. 
philosophy was formed in the Progressive Era, where it made sense. But as the Court changed hands and the world changed around them, some of these figures-Hand and Frankfurter, in particular-were unable or unwilling to make the turn to a new post-war understanding of judicial review. Given their status, they set the terms of the debate for the legal academy, even though many managed to glimpse the problem for what it was: historically contingent and outdated. ${ }^{23}$

The third—and perhaps most poignant-reason for the obsessive hold that the countermajoritarian problem had on these liberal academics was their need to imagine a countermajoritarian Court, even if one did not exist. ${ }^{24}$ For a public that had seen the ugly face of totalitarianism, there was broad support for an institution in a democracy dedicated to protecting minority rights. The same was true among many academics. But in light of their Progressive ancestry-which, recall, had threatened to discipline the Supreme Court by packing it during the New Deal-mid-century liberals lived with the anxiety that the public itself ultimately would turn on the Court and endanger a set of results these academics approved. The promise of a Court protective of liberty was dear to them, but they were sure such an institution inevitably would run afoul of popular opinion, and were skeptical that such an institution could exist or survive public disapproval. Thus, Bickel's "counter-majoritarian difficulty"- the problem of justifying judicial review in a democracy.

Although this project is mostly about history, Part II of the Article takes a moment to sharpen the distinction between what most constitutional theory frets over and a more philosophical concern about the legitimacy of institutions in a democracy. Part III then turns directly to responding to the historical claim-outlined above-that the countermajoritarian problem is one that has been with us always. This history demonstrates that quite unlike the Progressive Era, when the Court was criticized in countermajoritarian terms-academics at mid-century were worrying over judicial review in a way that was quite out of step with the world around them. Taken together, Parts II and III demonstrate that academic attention to the countermajoritarian problem is an obsession that needs explaining.

Part IV develops the reasons why the countermajoritarian problem took its hold on the legal academy at the time that it did. As this Part establishes, the countermajoritarian problem reflects the odyssey of liberal and Progressive thinking about the Supreme Court from the turn of the century to that point mid-century when liberal beliefs came into collision with themselves. At first, the stage was occupied by some of American law's most revered figures. Given the battles they had fought earlier in the

23. This argument is developed infra Section IV.B.

24. See infra Section IV.C. 
century against judicial protection of property and economic rights, it simply was impossible for them to turn the corner and accept activist judicial review even in areas for which they might have had ideological sympathy. But the central act was cast with a newer generation of liberal scholars, those who claimed to believe in the results of one reform decision after another. Nonetheless, these new liberals could not shrug off the teaching of their fathers, nor their anxiety about judicial review. It is this anxiety that they passed on to later generations and that we inherited.

Ever since Franklin Roosevelt appointed enough Justices to the Supreme Court to change its politics to the left of the political spectrum, liberal legal academics have struggled to justify judicial review. For them, the courts held the promise of equality and individual liberty, and the trick was to explain judicial review as the locus for those desired ends, while maintaining fidelity to democratic values. Today, the courts seem the last place to look for liberalism, and academics have begun to engage in a new round of Court-bashing - oddly reminiscent of the Progressive Eraquestioning, rather than justifying, the democratic pedigree of the judiciary. Perhaps now, as the worm turns yet again, it would be useful to step back and gain some perspective, to understand the historical context in which these arguments have been made before. Such perspective might even lead constitutional scholars to a new kind of constitutional theory.

\section{PRE-TEXT}

This Part explains, briefly, that the legal academic preoccupation with the countermajoritarian problem is separate and apart from a very real problem of political theory. It is possible to read all that follows as a claim that there is no real or interesting question regarding the democratic legitimacy of courts. But that reading would be a mistake. Political theorists and philosophers (and some legal academics, of course) have much valuable to say about what constitutes democracy and the norms of legitimacy for democratic institutions. The point here, however, is that this perfectly legitimate -indeed, deeply important-interest in democratic theory is not what drives most of the discourse in constitutional law and theory about the countermajoritarian difficulty.

Legal academics are preoccupied with judges and judicial review. If one were to judge from the corpus of constitutional scholarship over the last sixty years, of all of the institutions of American government, it is only the Supreme Court that presents a particular problem of democratic accountability. ${ }^{25}$ Constitutional scholars are fixated on the legitimacy of

25. C.J. Peters makes this point in extended fashion in Christopher J. Peters, Persuasion: $A$ Model of Majoritarianism as Adjudication, 96 NW. U. L. REV. 1, 7-9, 12 (2001) (noting 
constitutional courts. $^{26}$ They cannot stop talking about the countermajoritarian difficulty, ${ }^{27}$ and in their conversations, only courts present a problem.

The question is: Why? Is there something in the nature of judicial review that makes it worthy of examination against the backdrop of democracy? Of course. But for the theorist truly interested in democracy, virtually all of the institutions of American government similarly could be questioned; they all require justification.

An examination of what constitutional theorists do not write about highlights the point that they are obsessed with judicial review, rather than interested generally in democratic theory. ${ }^{28}$ When is the last time a constitutional scholar wrote an article about the democratic legitimacy of the Federal Reserve Bank ${ }^{29}$ Not a good article, just an article. For that matter, how often do legal academics write about the democratic bona fides of the United States Senate as an institution of government? ${ }^{30}$ Even

repeatedly the academic attention to courts and the lack of attention to shortcomings of majoritarian democracy).

26. See, e.g., Michael S. Moore, Justifying the Natural Law Theory of Constitutional Interpretation, 69 FORDHAM L. REV. 2087, 2099 (2001) ("The stubborn truths are that majority rule-the narrow, proceduralist sense of 'democracy'-is something good and that modern legislatures tend to realize this good more fully than do modern courts. Thus, the question of what can be said to justify this breach of democracy is a real one.").

27. Many make this point. See, e.g., Akhil Reed Amar, The Consent of the Governed: Constitutional Amendment Outside Article V, 94 COLUM. L. REV. 457, 495 (1994) (discussing preoccupation with the countermajoritarian difficulty); Chemerinsky, supra note 17, at 71 ("Most constitutional scholars for the past quarter-century ... have seen the task of constitutional theory as defining a role for the Court that is consistent with majoritarian principles."); Horwitz, supra note 17, at 63 ("The competing conceptions of democracy and its relationship to judicial review ... have framed the central debates in American constitutional theory during the past fifty years."); Neal Kumar Katyal, Judges as Advice-Givers, 50 STAN. L. REV. 1709,1709 (1998) ("Contemporary constitutional law is preoccupied with the antidemocratic nature of judicial review."); Steven L. Winter, Indeterminacy and Incommensurability in Constitutional Low, 78 CAL. L. REV. 1441 (1990) (discussing the "obsession" with the countermajoritarian difficulty).

28. For an exception that proves the rule, see Michael J. Klarman, Majoritarian Judicial Review: The Entrenchment Problem, 85 GEo. L.J. 491, 502-28 (1997) (describing numerous ways that the American political system entrenches the status quo against majority will).

29. This is actually more than a little interesting. At the time the Fed was established, the debate was between those who wanted a central bank under private control, and those who insisted on public control. ARTHUR S. LINK, WILSON: THE NEW FREEDOM 199-240 (1956) (describing this debate). Luminaries such as William Jennings Bryan and Brandeis favored public control. Id. at 207, 212; see also id. at 223-24 ("'The issue,' the spokesman of Roosevelt's Progressive party agreed, 'is between private regulation by a group of men elected in a directors' room, and public regulation by a group of men in regard to whose choice the entire country has a voice after the fullest publicity and discussion."' (quoting OUTLOOK, Aug. 9, 1913, at 796)). But even under a public-control model, members of the Federal Reserve Board have much the same autonomy as Supreme Court Justices, and their appointment is similar. See Federal Reserve Act, Pub. L. No. 63-43, \& 10, 38 Stat. 251, 260 (1913) (providing that board members are appointed to ten-year terms by the President upon the advice and consent of the Senate and are removable only for "cause").

30. The answer? Not often. But see Lynn A. Baker \& Samuel H. Dinkin, The Senate: An Institution Whose Time Has Gone?, 13 J.L. \& POL. 21 (1997). 
administrative agencies get off relatively easy on the accountability front when it comes to constitutional (as opposed to administrative law) scholarship. ${ }^{31}$ Yet all of these institutions have a profound impact upon all of us-perhaps each of them far more than constitutional courts-and all have their problems when it comes to a democratic pedigree. Moreover, most, if not all, of these other institutions are within the intellectual and professional ambit of legal scholars.

Most constitutional scholarship in which the countermajoritarian difficulty is discussed is not even actually devoted to examining the question of whether judicial review is consistent with democracy in any deep philosophical or theoretical sense. ${ }^{32}$ Often, the countermajoritarian problem is but a twitch that cannot help but make a brief but repeated appearance in scholarship on constitutional interpretation. ${ }^{33}$ At other times,

31. Deference under the Chevron principle is justified in part (by courts) based upon the greater accountability of administrative agencies. Especially with regard to independent agencies, under control of officials appointed much like Supreme Court Justices, this claim is more than a little difficult to support, yet has received insufficient attention in the literature. E-mail from Rachel E. Barkow, Assistant Professor of Law, NYU School of Law, to Barry Friedman (Apr. 9, 2002) (on file with author).

32. Having said that, exceptions do exist. See, e.g., ChristoPHER L. EISGRUBER, COnstitutional Self-Government (2001); Samuel Freeman, Constitutional Democracy and the Legitimacy of Judicial Review, 9 LAw \& PHIL. 327 (1990-1991); Frank I. Michelman, Brennan and Democracy: The 1996-97 Brennan Center Symposium Lecture, 86 CAL. L. REV. 399 (1998). Two worthy exceptions deserve note, and also comment, because in a sense they prove the rule. Both Ronald Dworkin and Jeremy Waldron have devoted extensive effort to this project of reconciling judicial review with democracy. See, e.g., RONALD DWORKIN, LAW'S EMPIRE (1986); RONALD DWORKIN, A MATTER OF PRINCIPLE 9-71 (1985); JEREMY WALDRON, LAW AND DISAGREEMENT 255-312 (1999). First, one might note that Dworkin and Waldron are philosophers, and most constitutional theorists are not. This does not mean that constitutional theorists could not take a philosophical approach to the question of the democratic legitimacy of judicial review (though most do not). But Dworkin's and Waldron's deeply philosophical approach might be as much a function of their philosophical training as their interest in judicial review. Second, even in the most extended and sensitive treatments there can be a failure to examine judicial review as it really operates in a democracy. Thus, Waldron's Law and Disagreement is one of what are too few treatments of judicial review that take a serious look at the way the legislative process operates. But despite the close look at, and defense of, the legislative process, absent from Waldron's volume is an equally hard-boiled assessment of how judicial review actually operates. The idea that judicial review removes questions from popular control pervades the book. Waldron attends to political science literature on the dysfunctions of legislatures, see, e.g., WALDRON, supra, at 28-30, but includes no discussion of political science literature on how judicial review functions. Similarly, Dworkin offers an extensive theory of how judges should decide cases-a theory he defends as consistent with democracy. But Dworkin offers an idealized view of judicial review, which takes little account of the literature suggesting how judges do decide cases. See, e.g., TeRri Jennings PerReti, In Defense of a PoltTiCaI. COURT (1999); Barry Friedman, The Politics of Judicial Review (2002) (unpublished manuscript, on file with author). Upon consideration of that evidence, Dworkin might be less convinced that judicial review actually does satisfy the demands of democratic theory.

33. See, e.g., Neal Kumar Katyal, Legislative Constitutional Interpretation, 50 DUKE L.J. $1335,1337-40$ (2001) (justifying the role of other branches in interpreting the Constitution by contrasting them to the unaccountability of judges); William K. Kelley, Avoiding Constitutional Questions as a Three-Branch Problem, 86 CORNELL L. REV. 831, 856 (2001) (making a brief obligatory argument about judicial review's consistency with democracy in an article about the 
the countermajoritarian difficulty serves only as a backdrop for a theory of judicial review that advances the author's own conception of what constitutional courts should ${ }^{34}$ - or more recently should not ${ }^{35}$-do.

Perhaps the best proof that we are dealing with an obsession is that most of the scholarship in which the countermajoritarian difficulty appears rests on an overly simplified and largely inaccurate understanding of American democracy. ${ }^{36}$ Deference to other brands of government is typically the frame for evaluating the work of constitutional judges ${ }^{37}$ and apparent anxiety over the legitimacy of judicial review has begun to produce increasingly creative (albeit somewhat stretched) descriptions of both democracy and judicial review. ${ }^{38}$ Such scholarship commonly

constitutional avoidance canon); David A. Strauss, Common Law Constitutional Interpretation, 63 U. CHI. L. REV. 877, 928-35 (1989) (making an extended argument about the common law nature of constitutional decisionmaking that arrives, inevitably, at the need to square this practice with democracy).

34. This was certainly the case with one of the most extended and famous examples of scholarship steeped in the countermajoritarian problem. JOHN HART ELY, DEMOCRACY AND DISTRUST: A THEORY OF JUdICIAL REVIEW (1980). A good recent example is CASS R. SUNSTEIN, ONE CASE AT A TIME: JUDICIAL MINIMALISM ON THE SUPREME COURT (1999).

35. The latest trend seems to be that, in light of the conflict with democracy, courts should do little or nothing at all. E.g., SUNSTEIN, supra note 34; TUSHNET, supra note 5; Mary Becker, Conservative Free Speech and the Uneasy Case for Judicial Review, 64 U. COLO. L. REV. 975 (1993) (arguing against binding judicial review in a democracy, particularly because it furthers the status quo and hurts women's interests). For discussions of this trend, see Christopher J. Peters, Assessing the New Judicial Minimalism, 100 COLUM. L. REV. 1454 (2000); and Stephen M. Griffin, Has the Hour of Democracy Come Round at Last? The New Critique of Judicial Review, 17 CONST. COMMENT. 683 (2000) (book review).

36. See Robert W. Bennett, Response: On Substantiation of Positive Social Theory, 95 Nw. U. L. REV. 977, 979 (2001) ("This fixation is puzzling, because the rest of American democracy is not sensibly thought of as "majoritarian."'). For an extended discussion of this phenomenon in the context of the most famous statement of the countermajoritarian difficulty, that of Alexander Bickel in The Least Dangerous Branch, see infra notes 289-302 and accompanying text. For a discussion of the fact that analyses of Article III judges as a unitary entity possessing life tenure are greatly oversimplified, see Judith Resnik, Uncle Sam Modernizes His Justice: Inventing the Federal District Courts of the Twentieth Century for the District of Columbia and the Nation, 90 GEO. L.J. 607 (2002).

37. See, e.g., Guido Calabresi, The Supreme Court: 1990 Term-Foreword: Antidiscrimination and Constitutional Accountability (What the Bork-Brennan Debate Ignores), 105 HARV. L. REV. 80 (1991) (differentiating among four types of judicial review based on the Court's relative willingness to override majoritarian legislative choices when confronted with fundamental rights claims); Richard H. Fallon, Jr., The Supreme Court: 1996 Term-Foreword: Implementing the Constitution, 111 HARV. L. REV. 56, 76, 81, 89 (1997) (returning repeatedly to the notion that doctrinal tests implementing constitutional provisions appropriately are grounded in the deference owed by courts to democratic institutions). The practice is criticized. See Chemerinsky, supra note 17 (offering extended argument that American democracy is not meant to be majoritarian); Lawrence G. Sager, The Incorrigible Constitution, 65 N.Y.U. L. REV. 893, 897 (1990) ("'O]ur constitutional tradition cannot plausibly be squared with the absolutism of popular sovereignty, and we should abandon the effort.").

38. See, e.g., Robert W. Bennett, Counter-Conversationalism and the Sense of Difficulty, 95 Nw. U. L. REV. 845 (2001) (redescribing American democracy as a "conversation" and then explaining why judicial review is problematic in that reimagined sense of democracy); Christopher J. Peters, Adjudication as Representation, 97 CoLUM. L. REV. 312 (1997) (arguing that the adjudicative process is itself "representative" and thus consistent with democracy). 
assumes, without argument, that legislative bodies are democratically legitimate, and that most of what judicial review is aimed at is overturning the decisions of such bodies. ${ }^{39}$ However, this understanding of judicial review ignores an entire body of scholarship questioning as an empirical matter whether either of these assumptions is true. ${ }^{40}$

A host of scholarly work has been done on how constitutional courts really operate, and how they interact with politics and popular opinion. That work strongly suggests that legislative enactments often do not enjoy majority support, that judicial decisions often do, that judges tend to reflect the views of the popularly elected President that appoints them, and that most of what courts invalidate is the work not of legislative bodies anyway, but of low-level, equally unaccountable administrative actors. ${ }^{41}$ Anyone immersed in this literature reasonably might wonder exactly what is the countermajoritarian problem that occupies constitutional theorists. Whatever the answer to this question, it is fair to conclude that it is not a timeless, immutable problem of political philosophy. After all, it does not in many instances even present an accurate view of the world in which we live, let alone that inhabited by our forebears.

39. For a discussion of prominent theorists who rely on overly simple descriptions of American democracy, see Barry Friedman, Dialogue and Judicial Review, 91 MICH. L. REV. 577, 586-90 (1993) (discussing definitions of majoritarianism in literature); and Steven L. Winter, $A n$ Upside/Down View of the Countermajoritarian Difficulty, 69 TEX. L. REV. 1881, 1921 (1991) ("Of course, the democratic objection to judicial review has never really depended on a candid assessment of the actual practices of democracy."). See also Becker, supra note 35 (casting judicial outcomes as contrary to majority rule); Calabresi, supra note 37 (assuming throughout that the nonjudicial political process is majoritarian). But see WALDRON, supra note 32, at 19-119 (offering an extended argument as to why legislative will prevails despite majoritarian defects); Michael C. Dorf, The Supreme Court 1997 Term - Foreword: The Limits of Socratic Deliberation, 112 HARV. L. REV. 4, 51-73 (1998) (offering suggestions for reforming the practice of judicial review in light of a candid assessment of the institutional limitations of the judiciary).

40. On the point that judicial review does not, as an empirical matter, tend to trump majoritarian legislative enactments, see GIRARDEAU A. SPANN, RACE AGAINST THE COURT 19-31 (1993) (explaining why the Supreme Court is constrained to act in a manner consistent with majoritarian preferences); Mark A. Graber, The Nonmajoritarian Difficulty: Legislative Deference to the Judiciary, 7 STUD. AM. POL. DEv. 35, 36 (1993) ("[J]ustices have most often exercised their power to declare state and federal practices unconstitutional only when the dominant national coalition is unable or unwilling to settle some public dispute ... [and] prominent elected officials consciously invite the judiciary to resolve those political controversies that they cannot or would rather not address."); Michael J. Klarman, What's So Great About Constitutionalism?, 93 Nw. U. L. REV. 145, 145, 188 (1998) (arguing that none of the common accounts of constitutionalism "provides a very satisfactory description of how our constitutional system operates," and that in reality the "Supreme Court, in politically unpredictable ways, imposes culturally elite values in a marginally countermajoritarian fashion"); and Seith F. Kreimer, Exploring the Dark Matter of Judicial Review: A Constitutional Census of the 1990s, 5 WM. \& MARY BILL RTS. J. 427 (1997) (explaining that in most cases of trial courts reviewing government action, constitutional norms are enforced against administrative officials and street-level bureaucrats, not majoritarian institutions). As to the nonmajoritarian nature of legislative decisions, there is, of course, a vast literature in the area of public choice. Insofar as that literature pertains to this issue, it is summarized in Friedman, supra note 39, at 639-42.

41. See Friedman, supra note 39. 
It would be good to see legal academics marry some of this empirical understanding of how judicial review operates to their theories of how it should operate. ${ }^{42}$ Even normative legal theory ought to be grounded in empirical reality. At the same time, legal academics should be more candid in their normativity. Not only is there a role for purely normative scholarship, this may be the forte of the legal academy. But even so, such scholarship would hold more value if it were forthrightly normative, rather than being dressed up as a solution to a longstanding theoretical problem. Whether legal academics can actually do this, however, may be a function of the same historical forces that define the countermajoritarian problem itself. Just as scholars at mid-century could not accommodate themselves to the indeterminacy of constitutional standards and the lack of sufficient guidelines to constrain judges, scholars today seem themselves reluctant to be normative without packaging it as something else, usually as a solution to the countermajoritarian problem. Perhaps this historicization of the problem will loosen those scholarly bonds.

\section{TEXT AND CONTEXT}

Beginning in 1940, academic discussion about judicial review and the Supreme Court diverged sharply from broader public commentary about the Court. This was a novel and portentous event. For most of history, academics swam in the flow of public commentary on the Court-both for and against. But as the Supreme Court became more liberal following the collapse of Franklin Roosevelt's Court-packing plan, the academy began a conversation with itself that often had little to do with what actually occupied the Supreme Court, or what the public thought of the Court's work. It is in this period that the modern-day obsession with the countermajoritarian problem was born.

In order to see how this is so, it is useful to distinguish criticism of the Supreme Court from theories of judicial review spun to justify the institution. It is obvious that courts will (and do) come under attack whenever they render decisions controversial to some segment of the public. The question is why those attacks sometimes take on that particular form - call it the "countermajoritarian criticism"- in which the judiciary is accused of interfering with popular will. This is a question with an answer, and it has terrific explanatory force during the period from 1940-1970. During that period, reaction to decisions of the Supreme Court looked much as one would expect, given the theory-from everyone, that is, but the self-

42. For an attempt to set out an agenda for dealing with the social science literature on judicial review, see Friedman, supra note 32. 
appointed aristocracy of the legal profession, "first-rate lawyers, ${ }^{, 43}$ judges, and law professors. From this aristocracy came great angst about the Court, and a struggle to justify judicial review.

To identify-and thus to understand-the divergence between popular criticism and the academic project of justification, it is necessary to understand what sort of commentary upon the work of the Warren Court could have been anticipated, and how academic commentary deviated from that which was expected. The theory that drives this Part is that countermajoritarian criticism will emerge when: (1) there is general acceptance of judicial supremacy; (2) there is a sense that constitutional meaning is relatively indeterminate, so that judges have broad discretion; (3) notions of popular democracy are prevalent; and (4) courts are rendering decisions that actually are contrary to the preference of a portion of the public large enough to deem itself the majority. The theory is intuitive to a certain extent and has been developed in part elsewhere. ${ }^{44}$ Yet, its application during the 1940s-1970s is significant enough to warrant a bit more examination.

This Part describes the reaction to the Supreme Court in the general public, demonstrating how the academic response deviated from that broader reaction, often in surprising ways. The next few pages provide the theory from which one could predict what popular reaction to the Court in the period from 1940-1970 would be. The balance of the Part reviews the work of the Court, indicating that the public reacted just as would be expected, but that-again, for the first time in history-the mainstream of academic commentary often seemed to be off on its own endeavor. It was. Academics had become fixated on the countermajoritarian problem.

\section{A. Theory}

\section{Judicial Supremacy}

Supremacy's importance is paramount yet oft-overlooked, in part because it has been a long time since the widespread denial of judicial supremacy. ${ }^{45}$ It is this very fact that leads us to think the countermajoritarian problem has always been with us. Supremacy could mean many things - from a claim that judicial rulings are binding on the parties, to a claim that nonparties have to respect those rulings, to a claim

43. Henry M. Hart, Jr., The Supreme Court, 1958 Term-Foreword: The Time Chart of the Justices, 73 HARV. L. REV. 84, 101 (1959).

44. See Friedman, supra note 10.

45. On the rise of judicial supremacy, sec Fricdman, supra note 12. Today academics dissatisfied with Supreme Court decisions are beginning once again to attack the idea. See generally Kramer, supra note 5. 
that the Supreme Court has exclusive authority to say what the Constitution means. ${ }^{46}$ Throughout history there have been arguments in favor of various of these interpretations. It is the middle one that matters most in this context-the claim that when the Supreme Court says the Constitution means something, government officials not party to the proceeding must comply with the decision. Without this form of supremacy, there is not much in the way of a countermajoritarian problem. Judicial decisions can simply be ignored or modified by the other branches.

Evidence of judicial supremacy was widespread during the period at issue here. In 1940, Arthur Krock-a New York Times correspondent who frequently wrote about the Supreme Court-noted on the occasion of the Court's 150th anniversary "the fact that on its birthday no important voice was heard to question its authority, function or essential value to the democratic process would seem clearly to prove that the American people are satisfied with the system of cyclical swings [of the Supreme Court]., As Henry Steele Commager observed, "We cannot overturn now the institution of judicial review, even if we would. ${ }^{48}$ Other than Southern claims of defiance to Brown, claims of nonsupremacy were rare throughout the entire period of the Warren Court. ${ }^{49}$ The common understanding was

46. See generally Friedman, supra note 10, at 351-54; Kramer, supra note 5.

47. Arthur Krock, Supreme Court Gives Proof of Its Vitality, N.Y. TIMES, Feb. 4, 1940, at 65; see also id. ("Cyclical Change is Approved"). It was the rare academic, such as Alexander Pekelis, writing in the New Republic, who was uncertain of judicial supremacy. Pekelis wrote:

[T] he constitutional position of the Court is extremely tenuous .... [T] the constitutional position of the Supreme Court is in the prestige it enjoys and in the readiness of political public opinion and of the people at large to protect it and to prevent any encroachment upon its powers.

Alexander Pekelis, The Supreme Court Today, New RePuBlIC, Apr. 17, 1944, at 522, 524-25; see also C. HeRman PRITCHetT, The Roosevelt CoURT: A STUdy IN Judicial Politics and VALUES 1937-1947, at 21 (1948) ("Dependent as it is, the Supreme Court enjoys the privilege of becoming unrepresentative only at its peril, for the methods of retaliation are readily available should the representative branches of the government have cause to resort to them."). A similar point was raised by Walton $\mathrm{H}$. Hamilton and George $\mathrm{D}$. Braden, who wrote:

If the legislature asserts that it has the final say, the judicial branch acts under its overlord and loses its independence. If the last word remains with the Court, the judiciary elevates itself into ascendancy over the legislature. As is usual with an institution not cut to blueprint, neither is supreme and fortunes vacillate.

Walton H. Hamilton \& George D. Braden, The Special Competence of the Supreme Court, 50 YALE L.J. 1319, 1335 (1941) (citing THOMAS JACKSON, THE STRUGGLE FOR JUDICIAL SUPREMACY (1941)).

48. Henry Steele Commager, Majority Rule and Minority Rights 38 (1943); Charles P. CURTIS, JR., LiONS UNDER THE Throne 12 (1947) ("A hole was left where the Court might drive in the peg of judicial supremacy, if it could. And that is what John Marshall did. $\mathrm{He}$ drove it in, so firmly that no one yet has been able to pull it out.").

49. Bernard Schwartz's writing offers one example of the prevailing deference toward the Supreme Court:

[T] here can be no Constitution without law administered through the highest Court. But this necessarily presupposes respect for and compliance with the law declared by the Court. When, in a real controversy, an appeal is made to law, the issue must be left entirely to the judgment of the high Court and not the personal judgments of those 
expressed by Alexander Bickel, who criticized the Southern Manifesto (the congressional Southerners' response to Brown) for its "suggestion, tenable only academically or by force but not in law, that there exists a Constitution distinct from the one the Supreme Court expounds." ${ }^{50}$ Perhaps the greatest test of that supremacy came in the Little Rock controversy, when President Eisenhower sent in federal troops to enforce judicial desegregation orders. ${ }^{51}$ In doing so, Eisenhower, speaking to the nation, observed that "the responsibility and authority of the Supreme Court to interpret the

interested. This principle is a basic postulate of our constitutional system. Indeed, respect for the Court's decisions is the sine qua non of our structure ....

BERNARD SCHWARTZ, THE SUPREME COURT: CONSTITUTIONAL REVOLUTTON IN RETROSPECT 274 (1957); see also Philip B. Kurland, The Supreme Court 1963 Term-Foreword: Equal in Origin and Equal in Title to the Legislative and Executive Branches of the Government, 78 HARV. L. REV. 143, 144 (1964) (referring to the "enhancement of judicial dominion" with respect to the Supreme Court at the expense of other branches of government); Ruling Tempers Reaction of South, N.Y. TIMES, May 18, 1954, at 20 (reporting Southern reactions to Brown, including those of the governor of Kansas who stated that the "long-litigated question has now been decided and is the law for all states of the nation, and the Kansas education procedure will have to ultimately be adjusted to comply with it," and Louisiana Senator Long who stated, "my oath of office requires me to accept [the decision] as the law"). But see JACK W. PELTASON, FEDERAL COURTS IN THE POLITICAL PROCESS 55, 58 (1955) ("The Constitution, or anything else, is what the judges say it is only when the judges represent the dominant interest within the community... [O]pen defiance and refusal to comply with court rulings are not unknown."); Kurland, supra, at 157 (noting that ten years after the Brown decision, little had changed in school desegregation).

50. Alexander M. Bickel, Ninety-Six Congressmen Versus the Nine Justices, NEW REPUDLIC, Apr. 23, 1956, at 11. The Conference of State Chief Justices, which issued a lengthy report in 1958 criticizing Supreme Court decisions threatening state autonomy, conceded freely that " $[\mathrm{b}] \mathrm{y}$ necessity and by almost universal common consent" the power to "give the ultimate interpretation to the Constitution" is "vested in the Supreme Court of the United States." Report of the Committee on Federal-State Relationships as Affected by Judicial Decisions, 32 ST. Gov'T 60, 61 (1959). For a fuller discussion of the State Chief Justices' report, see William G. Ross, Attacks on the Warren Court by State Officials: A Case Study of Why Court-Curbing Movements Fail, 50 BUFF. L. REV. 483, 515-26 (2002).

51. By its end, the Warren Court era also taught lessons about the divergence between the Supreme Court's supremacy in saying what the Constitution meant and its ability to ensure enforcement of those very same declarations. Even as early as 1955, the New York Times mused, in the wake of Brown II, "How can it be enforced?" Problem Arises in Enforcement, N.Y. TIMES, June 1, 1955, at 30. Political scientists of the period such as Robert Dahl and Jack Peltason observed early on that finality was different from supremacy, that supremacy depended on enforcement, and that in the long run it seemed the majority would get its way. In support of his argument that the "nine justices sitting on top of the federal court structure ... do not always determine with finality how interest conflicts shall be resolved," Jack Peltason cites the following historical examples:

The Supreme Cour decided that Congress could not ban slavery within the territories; eight years later slavery was banned throughout the United States. The Court told Congress that it could not make paper money legal tender; a year later Congress was still doing so and this time with the Court's blessings. The Supreme Court decided that Congress could not levy a graduated income tax without apportioning it among the states according to population, but less than twenty years later Congress did so.

PELTASON, supra note 49, at 63 (citations omitted). 
Constitution are very clear, ${ }^{, 52}$ and in a later press conference he reiterated that "[ $t]$ he courts must be sustained or it's not America." 53

\section{Constitutional Indeterminacy}

For most of the nation's early history, countermajoritarian criticism was more likely if there was a perception that judges were imposing their own values rather than adhering to some fixed understanding of what the Constitution required. During the controversies of 1800 , for example, the claim was that judges' partisan political views were driving them away from settled constitutional meaning. ${ }^{54}$ Throughout the Lochner era the claim was that class bias and laissez-faire economic views were causing judges to disregard the true meaning of the Constitution. ${ }^{55}$ By 1940, however, the bubble had burst on the idea that the Constitution had one true meaning. Indeed, the widespread acceptance of judicial supremacy was all the more interesting in light of equally widespread understanding that there was a lack of determinacy to constitutional adjudication, thus permitting the Justices broad discretion. Krock's 1940 article continued, "This satisfaction exists with full knowledge of the fact that the Constitution is merely what a majority of the justices say it is." 56

Throughout the period of the Warren Court there was general consensus that the Supreme Court enjoyed great flexibility in interpreting the Constitution, and that the idea of any one "correct" interpretation was

52. Eisenhower Address on Little Rock Crisis, N.Y. TIMES, Sept. 25, 1957, at 14.

53. Anthony Lewis, Eisenhower Calls Courts' Sanctity Little Rock Issue, N.Y. TIMES, Oct. 4, 1957, at 1. President Eisenhower continued: "[The troops] are there to uphold the courts of the land, the courts in whose hands are all our freedoms and our liberties, our protection against autocratic government." Id. The editorial page of the New York Times, commenting on the assertion of judicial supremacy in Cooper v. Aaron, said, "It should not be necessary in this year of 1958 - but apparently is - for the Supreme Court to have to issue a reminder that the interpretation of the Fourteenth Amendment enunciated by this court ... is the supreme law of the land' ...." Spelling Out Desegregation, N.Y. TIMES, Sept. 30, 1958, at 30.

54. See Friedman, supra note 10, at 380-81 (indicating that critics believed partisan politics influenced judicial decisions).

55. Friedman, supra note 6.

56. Krock, supra note 47, at 65. Krock goes on to assert that

the fallibility or prejudice of the majority has often been proved by the eventual triumph of dissents, and ... the rejected political philosophy of a President, through the system of life tenure, often guides the Supreme Court for years after it has been succeeded by one more compatible with new times and conditions.

Id. This sense of constitutional indeterminacy no doubt was a vestige of both Legal Realism and the 1937 Court-packing fight. Legal Realism, born out of the Lochner era struggles, preached that judicial decisions often were the result of judicial disposition. See infra notes 303-319 and accompanying text. During the New Deal fight, this criticism became a positive force for change: Critics of the Supreme Court insisted that the Constitution was capacious enough to take on new meanings necessitated by changed circumstances, but that the judges were recalcitrant, or simply too old to see that times had changed. Barry Friedman, The History of the Countermajoritarian Difficulty, Part Four: Law's Politics, 148 U. PA. L. REV. 971, 1020-22 (2000). Thus, what at the tum of the century had been a vice, by 1937 became a virtue. 
elusive. While discussing how the Court had been "demythologized," Professor Lloyd Wells stated that "after 1937 the notion of a fixed constitution and of judges controlled by an objective, external entity called 'law' was examined and rejected by an ever increasing number of scholars, teachers, publicists, and other opinion leaders whose function it is to interpret the Court to the public at large." ${ }^{57}$ Even toward the end of the Warren Court, conservative commentators such as James J. Kilpatrick would acknowledge (bowing to reality, if not altogether happy about it) that " $[t]$ he Constitution . . . is what the judges say it is."

\section{Democracy}

Another factor influencing the emergence of countermajoritarian criticism is the prevalent understanding of democracy. ${ }^{59}$ This factor also is intuitive. The more that political understandings are relatively populist, or call for direct democracy, the greater the likelihood that judges exercising the power of judicial review will be accused of thwarting popular will. Thus, countermajoritarian criticism was prominent after the democratic "revolution" of $1800^{60}$ and throughout the Populist-Progressive Era. ${ }^{61}$

Notions of democracy were in tremendous flux throughout the period from 1940 to 1970 , and, as will become evident, this dynamic state of affairs had a significant impact on the way controversial decisions were regarded. At the outset of the period, totalitarianism abroad was on the public mind. There was a widespread concern for minority group rights and support for the role of the Supreme Court in protecting those rights. ${ }^{62}$ Later in the period, a strong egalitarian and democratic strain manifested itself in large social movements, helped along - it is worth mentioning - by the Court itself. ${ }^{63}$ By the end of the Warren Court, claims of minority group

57. Lloyd M. Wells, The Supreme Court and Public Opinion 1937-1957, in THE POLITICS OF JUDICIAL REVIEW 1937-1957, at 33, 36 (John M. Claunch ed., 1957).

58. James Jackson Kilpatrick, $A$ Very Different Constitution, 21 NAT'L REV. 794, 795 (1969).

59. For an excellent discussion of the relationship between the political theory of democracy and the events that shaped it, see EDWARD A. PURCELL, JR., THE CRISIS OF DEMOCratic THEORY: SCIENTIFIC NATURALISM \& THE PROBLEM OF VALUE 235-72 (1973).

60. See Friedman, supra note 10.

61. See Friedman, supra note 6.

62. See COMMAGER, supra note 48 (complaining about just this phenomenon); see also PURCELL, supra note 59, at 254 ("The belief that American society was pluralistic led to a revival in the fifties of the group theory of politics."); ANTHONY J. SEBOK, LEGAL POSITIVISM IN AMERICAN JURISPRUDENCE 173 (1998) ("Pluralism was clearly well suited to the mood of American scholars in the 1950s: It defended American democracy by arguing that group conflict and value relativism were the best defense against totalitarianism.").

63. As Robert McCloskey said, commenting on the reapportionment decisions, "[I]t may be that most Americans have come to think of some version of the majority principle as at least the presumptive democratic standard." ROBERT G. MCCLOSKEY, THE MODERN SUPREME COURT 267 (1972). 
rights morphed into issues of "individual rights," thus more likely to come into conflict with majority will. ${ }^{64}$ Martin Shapiro's lengthy discussion of Baker v. Carr-focusing on the complexities of majority representation and the role of groups - captured much of the confused debate about democratic theory during this period. ${ }^{65}$ Most perceptive perhaps was his comment that "much of the concern is not really for a cohesive philosophy [of democracy], which seems patently impossible at the moment, but for a unified ideology to use as a weapon against that other supposedly unified ideology, communism." ${ }^{\text {.66 }}$ All of this mirrored developments in the academy. ${ }^{67}$

\section{The Court's Work (and the Idea of the Majority)}

Given prominent understandings of judicial supremacy, the relative unimportance of indeterminacy during this period (as opposed to its importance, during the earlier Populist-Progressive Era, or subsequent concern on this score raised by unenumerated rights decisions like Roe $v$. Wade), and shifting views on democracy, perhaps the factor that could most be expected to account for public reaction was what the Court actually was doing. The Court's own decisions obviously have an impact on the way its work is regarded. Losers in the Supreme Court often attack it. If the decision frustrates majority will, the Court is more likely to be attacked in countermajoritarian terms. On the other hand, if the decision interferes with the preferences of a minority, criticisms of the decision are likely to take a different tone. Federalism and states' rights arguments often have been the refuge of losing minority groups asserting a right to go their own way. Such, for example, was the case during the nullification crisis in the $1820 \mathrm{~s} .{ }^{68}$ And such was the case in response to Brown v. Board of Education. ${ }^{69}$

This raises the question: What does it mean for a judicial decision to be countermajoritarian? What is the relevant majority? Take, for example, a situation common to the times: The Supreme Court strikes down a law that has been passed by several state legislatures, although it is safe to say that a

64. See Gary Chamberlain, Crime, Confessions and the Supreme Court, AMERICA, July 8, 1967 , at 32 (noting the problem in a democratic society of balancing public security with the protection of individuals' rights); Concern About Confessions, TIME, Apr. 29, 1966, at 52 ("We deal not with the criminal against society, but the state and the individual." (quoting Justice Fortas)); Rewriting the Rules, NEWSWEEK, June 27, 1966, at 21 ("It is the private arena where the right of society to peace and good order is placed in balance against the right of the individual to fair play.").

65. MARTIN SHAPIRO, LAW AND POLITICS IN THE SUPREME COURT 216-311 (1964).

66. Id. at 219.

67. See infra note 288 and accompanying text.

68. See Friedman, supra note 10, at 410-13.

69. See infra notes 142-146 and accompanying text. 
majority of the population nationally is in agreement with the Court's ruling. Is the ruling "countermajoritarian" because it thwarts a majority in the state, or majoritarian as reflecting a national consensus?

Understand that the answer to this question is-for present purposes-a historical one. It is possible to debate as a matter of political theory whether what matters in assessing the work of the Supreme Court is the view of a national majority, or whether the Court acts in countermajoritarian fashion if it trumps the will of the majority within a specified governing territory, such as a state. But for present purposes what matters is not an answer to this question as a matter of current practice or political theory, but what people at the time regarded as the relevant majority when assessing the Supreme Court's work.

Historically, the answer differed somewhat among academics and the general public. Nonetheless, the tendency in both quarters was to see the relevant majority as a national one, albeit for different reasons. To the extent there were exceptions, they tended to be self-serving.

For almost all academic commentators-critics and proponents of the Warren Court alike-the relevant question was whether a national majority supported a Court decision. Several academic critics of the Court were quite explicit on this score. Thus, for example, discussing the school desegregation cases, Alexander Bickel said, "[E]ven if the task of the Court were, in Mr. Dooley's phrase, to follow the election returns, surely the relevant returns would be those from the nation as a whole, not from a white majority in a given region. Fragmented returns cannot count, any more than early ones. ${ }^{, 70}$ Academic consistency on this score was apparent in the debate over applying the Bill of Rights against the states through the vehicle of "incorporation." incorporation" 72 strategy were attacked, but even those who disagreed with the Court's particular approach nonetheless agreed that state laws ought properly to fall in the face of national consensus. ${ }^{73}$

70. BICKEL, supra note 16 , at 250.

71. See infra notes 88-90 and accompanying text (discussing incorporation).

72. "Selective incorporation" referred to the practice of applying certain provisions of the Bill of Rights, but not others, to the states on an individual basis, rather than holding them all applicable, or all not. See infra note 88 .

73. On this point, Wechsler observed that the Court's majority purports to rely more upon the text of our basic charter and less on the robust avowal and defense of its positions as an exercise of judgment as to what Americans may rightly be admonished contravenes the basic values of the Nation. It is, however, only on the basis of such judgment that the Fourteenth Amendment gives the Court a title to supplant the states in shaping our civil rights and liberties....

HERBERT WECHSLER, THE NATIONALIZATION OF CIVIL LIBERTIES AND CIVIL RIGHTS 20 (1970); see also BICKEL, supra note 16, at 33, 250 (expressing reservation about the judicial role in trumping state laws, but stating clearly that national will should prevail over local majorities on questions of rights); Henry J. Friendly, The Bill of Rights as a Code of Criminal Procedure, 53 CAL. L. REV. 929, 953-54 (1965) ("My submission . . . is that in applying the Bill of Rights to the 
Among the broader public it also was the national majority that mattered, but commentary on the Supreme Court was more likely to be influenced by perceptions of national public opinion than by the technical question of whether the Court was striking down a national law, a state law, or, for that matter, a police regulation sanctioned by no legislative body. For example, Brown v. Board of Education involved de jure segregation and thus raised the specific issue of whether trumping a state majority was countermajoritarian. National public opinion was strongly supportive, ${ }^{74}$ and even Southerners enraged by Brown did not for the most part accuse the Supreme Court of acting in countermajoritarian fashion. ${ }^{75}$ As will be clear momentarily, they saw themselves as in the minority and relied far more heavily upon arguments grounded in respect for minority viewpoints and states' rights than in countermajoritarian criticism. ${ }^{76}$ Of course, when minority opinion was congruent with state boundaries, those within a state would fall back upon the self-serving argument that states' rights required as a matter of constitutional law that their will should prevail.

Reaction to Miranda v. Arizona was to similar effect. Miranda and its companion cases for the most part involved no laws that could be said to have majority support within the conceptual framework of the countermajoritarian difficulty. Too often, those who discuss the countermajoritarian problem fail to recognize that much of what constitutional courts do is invalidate the work of administrative or police officials, whose decisions can only dubiously be called "majoritarian." Yet what apparently mattered in public commentary in response to Miranda was a perception that the view opposed to the Court's had majority support.

states, the Supreme Court should not regard these declarations of fundamental principles as if they were a detailed code of criminal procedure, allowing no room whatever for reasonable difference of judgment or play in the joints."); Louis Henkin, "Selective Incorporation" in the Fourteenth Amendment, 73 YALE L.J. 74, 79 (1963) (arguing for selective incorporation of substantive rights, but calling for an "ordered liberty" formula for procedural rights); id. at 82 ("[A]ccepting the need or the desirability of increasing constitutional protections against the states, one may yet ask whether [the selective incorporation] doctrine is really necessary.").

74. See infra notes 132-141 and accompanying text.

75. See infra text accompanying note 144 .

76. See infra notes $142-146$ and accompanying text.

77. See Friedman, supra note 39, at 634-48 (making this point at length); Kreimer, supra note 40 (making this point with regard to lower courts); see also Matthew D. Adler, Judicial Restraint in the Administrative State: Beyond the Countermajoritarian Difficulty, 145 U. PA. L. REV. 759, 763 (1997) (pointing out the "error in conflating judicial review ... with the review of statutes" and noting that "[j]udicial review includes, as an instance, the invalidation of statutes ... but it also includes the invalidation of agency rules, agency orders and simple actions such as streetlevel searches or the treatment of prisoners"). Bickel acknowledged this, and argued that as between the two-Court decision and administrative act-the latter was more legitimate because administrative actors are themselves accountable to those accountable to the majority. See BICKEL, supra note 16, at 19-20 ("[These officials] are most often responsible to officials who are themselves elected and through whom the line runs directly to a majority...."). But surely this is a tenuous argument when it comes to police officials, and certainly to the stray acts of officers that are not nearly as widespread even as obtaining confessions without warnings to the suspect. 
In other words, those who opposed the Court clearly saw themselves as in the majority and thus able to level the countermajoritarian criticism. ${ }^{78}$ The reaction to Miranda was quite strong in these terms.

It is thus possible to conclude that for the most part an act was "countermajoritarian" if it trumped national majority will, rather than that of a subunit of the national government. The alternative view was heard only rarely, primarily by those who were certain national opinion was against them. Dominant opinion favored the idea of a national majority, at least with regard to most of the rights issues that confronted the Warren Court.

\section{In Sum}

Juxtaposing these four factors against the work of the Supreme Court throughout the 1940s-1970s suggests one might anticipate different sorts of criticisms at different times, depending upon how a national majority felt about what the Court actually was doing. And that is what happened. Yet, it will be equally apparent from the discussion that follows that the logic of popular reaction to the Supreme Court eluded intellectuals and academia.

The balance of this Part is history. It tells the story of the Supreme Court at mid-century, and of the public's and legal academy's divergent reactions to it. The story proceeds in chronological layered installments, first describing what the Court was doing, and public reaction to it, then turning to the academy's consistently odd response. What emerges is the picture of an academy deeply troubled by the question of judicial review. The next Part explains why this preoccupation with judicial review developed when it did, and in the way it did.

\section{B. History}

1. 1939-1951: The Lull ... and the Seeds

\section{a. The Court Does Little and Garners Little Reaction}

During the 1940s, for the first time in history, "the Court found itself in the unprecedented situation of being the most liberal branch of the government." ${ }^{.79}$ By the time he passed away, Franklin Delano Roosevelt had

78. See infra notes 268-271 and accompanying text.

79. PRITCHETT, supra note 47, at 14; see also Pekelis, supra note 47, at 522 ("The Federal Judiciary, led by its Supreme Court, may well prove to be ... the most liberal of the three branches of the national government."). 
appointed eight of the Court's nine members. ${ }^{80}$ The appointees were low on judicial experience ${ }^{81}$ and high on exposure to politics and government. ${ }^{82}$ And, as Supreme Court Justices go, they were young. Indeed, Life's 1945 article on the Court, no doubt emphasizing the change from early New Deal days, was entitled The Nine Young Men. ${ }^{83}$ "The great traumatic experience of the life time of those men, in relation to the Constitution, was the excess of judicial supervision of American affairs before 1937.,84

Insofar as the protection of economic rights was concerned, it soon became clear that the New Deal battle had been fought, and unconditionally won. Professors Walton H. Hamilton and George D. Braden could relegate to a footnote the fact that "cases upholding recent economic legislation under the Fourteenth Amendment are too numerous to mention." observed that " $[t]$ he problem of the constitutionality of New Deal legislation would not flutter a hair (even Burton's) in Saturday conference today." 86

As economic issues moved largely off the Court's plate, ${ }^{87}$ issues of the meaning of constitutional liberty began to take on significance. The range of liberties cases was not vast, however, largely because most of the rights in the Bill of Rights still were not applied against the states. It was not until

80. Thomas Reed Powell, Our High Court Analyzed, N.Y. TIMES, June 18, 1944, $\S 6$ (Magazine), at 17.

81. Justice Rutledge had served for two years on the United States Court of Appeals for the District of Columbia Circuit. PRITCHETT, supra note 47, at 13 . The only other Justice appointed by Roosevelt with judicial "experience" was Justice Black, who, "as his detractors were fond of pointing out," had served " 18 months as a police judge in Birmingham." Id.

82. See John Chamberlain, The Nine Young Men, LIFE, Jan. 22, 1945, at 76, $78-79$ (giving a brief biographical sketch of each Justice); Jonathan Daniels, The Battle of the Bench, CoLLIER's, Aug. 17, 1946, at 12 (observing that five of the Justices had been elected to public office); Arthur M. Schlesinger, Jr., The Supreme Court: 1947, FoRTUNE, Jan. 1947, at 73, $74-78$ (discussing the backgrounds and judicial attitudes of the Roosevelt Justices). Three Justices, Douglas, Frankfurter, and Rutledge, also had academic experience. PRITCHETT, supra note 47, at 13.

83. Chamberlain, supra note 82, at 76 (emphasis added); see also PRITCHETT, supra note 47 , at 13 ("The previous Court with its nine old men had reached the average age of 72 by 1937. In 1943, when Roosevelt's last appointment had been made, the average age of the Court was $\mathbf{5 6}$ years."); Schlesinger, supra note 82, at 73 ("These are young men by Supreme Court standards: the oldest cannot qualify for a pension till 1952.").

84. John P. Frank, Court and Constitution: The Passive Period, 4 VAND. L. REV. 400, 425 (1951)

85. Hamilton \& Braden, supra note 47 , at 1345 n.98.

86. Schlesinger, supra note 82 , at 201.

87. This is not to say that economic issues disappeared entirely. Issues regarding state authority in a national economy had some prominence. See PRITCHETT, supra note 47, at 81-90 (discussing the Commerce Clause and state tax issues of the day); Robert E. Cushman, Constitutional Law in 1939-1940, 35 AM. POL. SCI. REV, 250, $279-83$ (1941) (discussing decisions affecting state taxation); see also Earl M. Maltz, The Impact of the Constitutional Revolution of 1937 on the Dormant Commerce Clause-A Case Study in the Decline of State Autonomy, 19 HARV. J.L. \& PUB. POL'Y 121 (1995) (heralding this period as a turning point in the subjects of Supreme Court concern). In addition, many issues of economic liberty translated into discussions about the authority of administrative agencies. See PRITCHETT, supra note 47 , at $167-$ 97; Cushman, supra, at 260-62. 
later, during the $1950 \mathrm{~s}$ and $1960 \mathrm{~s}$, that the approach of selective incorporation-by which the Court determined clause-by-clause which parts of the Bill of Rights governed state conduct-would prevail. ${ }^{88}$ The First Amendment had been applied to the states, ${ }^{89}$ and First Amendment liberties posed the most troubling and controversial questions for the 1940s Court. ${ }^{90}$ Issues raised by the war, the threat of communism, and religious issues (prominently provoked by Jehovah's Witnesses) got top billing. ${ }^{91}$ Also increasingly present on the docket were questions of racial segregation, particularly in schools. ${ }^{92}$ The rights of criminal defendants had begun to attract the Court's attention, with federal defendants prevailing more often than state ones, reflecting federalism tensions inherent in the incorporation debate. ${ }^{93}$ Concern about the treatment of criminal defendants also involved questions of race, and when the two conjoined, liberty was likely to find greater protection.

The telling feature of the 1940s, however, is that although the issues on the docket held the potential for conflict, the Supreme Court was not doing much to arouse attention, let alone popular ire. ${ }^{94}$ In 1941, Hamilton and

88. "Incorporation" refers to the process of applying the guarantees of the Bill of Rights against the states, which was accomplished by "incorporating" them into the "liberty" protected from state interference by the Fourteenth Amendment. See, e.g., Adamson v. California, 332 U.S. 46 (1947) (holding that the Fifth Amendment privilege against self-incrimination was not incorporated into the Fourteenth Amendment); Betts v. Brady, 316 U.S. 455 (1942) (holding that the Fourteenth Amendment does not incorporate a right to a court-appointed attorney for an indigent defendant in a state court proceeding, absent special circumstances); Palko v. Connecticut, 302 U.S. 319, 325 (1937) (holding that the protection against double jeopardy was not applicable against the states because this right was not "implicit in the concept of ordered liberty"); see also PRITCHETT, supra note 47, at 137-38; John P. Frank, Liberty Against Government, 24 IND. L.J. 139, 143 (1948) (reviewing EDWARD S. CORWIN, THE RISE, FLOWERING AND DECLINE OF A FAMOUS JURIDICAL CONCEPT (1948)). Frank gets credit for prescience of a sort. Referring to incorporation, he said, "This is a minority conception, but four man dissents have a way of becoming law." Frank, supra, at 143.

89. See Gitlow v. New York, 268 U.S. 652 (1925) (holding that the First Amendment is among the fundamental rights incorporated into the Fourteenth Amendment Due Process clause).

90. See Paul A. Freund, The Supreme Court and Civil Liberties, 4 VAND. L. REV. 533, 552 (1951) (discussing the enforcement of First Amendment guarantees under the Fourteenth Amendment); Elliot L. Richardson, Freedom of Expression and the Function of the Court, 65 HARV. L. REV. 1, 24-54 (1951) (analyzing the Court's role in First Amendment decisions).

91. See Minersville Sch. Dist. v. Gobitis, 310 U.S. 586 (1940) (upholding a law requiring students to participate in a daily ceremony to salute the American flag, regardless of their religious beliefs); CURTIS, supra note 48, at 261-67, 300-18 (focusing on free speech, the "red scare," and the Gobitis decision).

92. See Frank, supra note 84, at 407 (observing that the Court acquiesced in the segregation of Japanese Americans during World War II, but that after the war ended, the Court retreated from this position, with "some Justices ... flatly denounc[ing] racism" and segregation); Louis Lusky, Minority Rights and the Public Interest, 52 YALE L.J. 1, 30-32 (1942) (summarizing the Court's involvement in segregation cases).

93. See COMMAGER, supra note 48, at 64-65 (listing examples of state legislative interference with federally protected civil liberties); Hamilton \& Braden, supra note 47, at 1367-69 (reflecting on the Court's role as "umpire" in federal-state tensions).

94. It might be more accurate to characterize the $1940 \mathrm{~s}$ as two separate periods, with the period from 1940 to 1945 as a more activist one for the Court. The dividing point would be the 
Braden remarked, "The best evidence of a change in attitude is that the Court has receded from the front pages." 95 In 1946, still alarmed by the 1937 New Deal Court-packing plan, members of the Association of the Bar of the City of New York suggested that given the calm surrounding the Supreme Court at present, the time was ripe for constitutional amendments to protect the Court, as they said: In Time of Peace Prepare for War. ${ }^{96}$

This quiet surrounding the Supreme Court resulted from the fact that the Court was deciding very few cases against the government-state or federal-and the exceptions often met with popular approval. ${ }^{97}$ Decisions in

death of Chief Justice Stone in 1946, and the appointment of Fred Vinson to succeed him. See MCCLOSKEY, supra note 63, at 57. Thus, McCloskey devotes chapter 2 of his book to the libertarian creed of the Stone Court during the early 1940s. Id. Nonetheless, if one reads carefully, it is clear that there are still "curious gaps" in the pro-civil liberties part of his pre-1946 story, id. at 28 , and that he has to back away from his strong claims, see id. at 35 (describing, for example, failures in criminal procedure). In any event, the Court was doing very little to arouse public anger, as discussed above. During this period, the Court struck down but one act of Congress, and a relatively insignificant one at that. Writing in 1945, Chamberlain noted:

[O]nly once has the court thrown down an act of Congress since 1937, and that was on a minor issue of gun toting by a civilian who claimed as a defense that it was not proven that his unregistered weapon had come to him through interstate commerce. The court would not allow a Congressional act to convict a man on mere "presumption of guilt."

Chamberlain, supra note 82, at 79. Much of the Court's power of review was directed at state, not national, activity. Some, such as Henry Steele Commager, resented judicial review even when directed at state laws, but several commentators raised the pertinent question whether the activity of one state with regard to, say, the "third degree," really represented national consensus. COMMAGER, supra note 48 , at 64-65. On the state versus national distinction, see id; Hamilton \& Braden, supra note 47, at 1355; Lusky, supra note 92, at 15-19; and Charles E. Wyzanski, Jr., Book Review, 57 HARV. L. REV. 389, 390-91 (1944). See also supra notes $70-78$ and accompanying text.

95. Hamilton \& Braden, supra note 47, at 1323.

96. Edwin A. Falk, In Time of Peace Prepare for War, 1 ReC. ASS'N BAR CITY N.Y. 245 (1946). Even the Court's overruling of precedents during this period attracted little attention outside the organized bar. The second big story about the Court during the period had to do with the large number of precedents being overruled. Pritchett counted thirty-two overrulings during the period from 1937-1946. PRITCHETT, supra note 47, at 57. The wave of overrulings led Justice Roberts to his comment that adjudication was coming "into the same class as a restricted railroad ticket, good for this day and train only." Smith v. Allwright, 321 U.S. 649, 669 (1944) (Roberts, J., dissenting). An article in the ABA Journal called the turn of events "The New Guesspotism," and commentators fretted that "lawyers feel like advising their clients to push cases as men bet on horse races, just for the sake of the gamble." Frank W. Grinnell, The New Guesspotism, 30 A.B.A. J. 507, 525 (1944); Chamberlain, supra note 82, at 77; see also Chamberlain, supra note 82, at 76 ("Even members of the Roosevelt High Court have admitted officially that the lower courts and the bar can no longer even guess with any degree of accuracy at what the law will be tomorrow."); Powell, supra note 80 , at 44 ("Where shall confidence be placed? How far will transactions become a mere gamble as to their legal results? These are questions which many lawyers are now asking."). Nonetheless, the sorts of cases being overruled were not likely to catch the public's attention. Most of the overrulings were of doctrines such as intergovernmental tax immunity, or were of statutory precedents. PRITCHETT, supra note 47, at 57-70; Powell, supra note 80, at 44. As Thomas Reed Powell explained, the differences between past and current precedents "are confined pretty much to what from a long-range view may be regarded as relatively minor matters." Powell, supra note 80 , at 44.

97. For this reason, important decisions like Korematsu and Dennis were unlikely to arouse the public against the Court. See, e.g., ARTHUR J. SABN, IN CALMER TIMES: THE SUPREME 
favor of the government tended not to raise a big stir, and certainly not one sounding in countermajoritarian terms. Robert E. Cushman, writing in 1943, described how civil liberties issues had moved to the fore, and then described all the ways government was violating them, often with the Court's sanction. ${ }^{98}$ Later in the decade, in his article The Passive Period, John Frank wrote, "The affirmative influence of the Court and the Constitution on American life since 1946 has been very little." "If an historian were to do a one-volume study of American life in the 1940s," Frank continued, "he might very well omit any reference to the CourtConstitution, 1946-50."100 The reaction to the Barnette case, one of the most notable pro-liberties decisions of the era, was largely favorable. ${ }^{101}$

Any possibility of a more aggressive - and thus more controversialexercise of judicial review was eliminated when the late 1940s brought further change to the Court, including the loss of two staunch voices for civil liberties, Murphy and Rutledge. ${ }^{102}$ In the stead of departed Justices (also including Chief Justice Stone) came new voices-Vinson, Burton, and

COURT AND RED MONDAY 86-87 (1999) (noting that "[ $[$ the reaction to the Dennis decision in the mass media was predictably positive" and describing the few dissenting voices).

98. Robert E. Cushman, Civil Liberties, 37 AM. POL. SCI. REV. 49 (1943).

99. Frank, supra note 84, at 400 . "The docket turned up opportunities which, had the Court chosen, might have resulted in striking developments, and this without absurd stretchings of doctrine." Id. at 418. This applied to cases "which the Court chose to hear"; Frank suggested that the "possibilities for action were... far, far greater among the cases on which certiorari was denied." Id. at 418 n.76 (emphasis added).

100. Id. at 418. Race-relations issues were the exception. In this area, "Congress, constantly urged to act, never acted. The Executive and the Court itself formulated and declared the national policies." Id. at 407.

101. For example, in response to Barnette, the New York Times wrote:

The Supreme Court has often justified Mr. Dooley's statement that it follows the election returns. It still does. Also, justices have managed frequently to find law to cover legislation carrying out their own and their group political philosophies when other justices have said no law exists. But when the court rises to its full height it proves its claim to be regarded as one of the great prides of American democracy, despite the human failings which it shares with all other thinking animals. Today was one of those when the Supreme Court rose to its full height as champion of the lowly, the laws and those exceptions to the laws which were written in the Bill of Rights.

Arthur Krock, The Supreme Court at Its Peak, N.Y. TMMES, June 15, 1943, at 29; see also DAVID R. MANWARING, Render unto CAEsar: The FlaG-Salute Controversy 236-40 (1962) (summarizing the media reaction to Barnette); Upholding a Principle, ATLANTA ConST., June 16, 1943 , at 6 ("As for the non-saluters ... while we disagree entirely with their fanaticism, we rejoice in a court decision that assures, even to fanatics, fullest freedom of religion as well as of speech, of press and of assembly. For that is what America means."). Oddly enough, this decision that the school children could not be compelled to salute the flag because of religious objections was handed down on June 14th-Flag Day. In sharp contrast to Barnette was the reaction, or lack thereof, to the issuance of Gobitis, a decision that was twenty-fifth page news. See Compulsory Flag Salute Upheld by Supreme Court in School Case, N.Y. TIMES, June 4, 1940, at 25; Problem in Freedom, N.Y. TIMES, June 5, 1940, at 24 ("Those of us who are unleamed in the law, and whose opinions do not become law are probably not in disagreement with either the majority or minority of the court in this case.").

102. Irving Dilliard, Truman Reshapes the Supreme Court, ATLANTIC MONTHLY, Dec. 1949, at 30 . 
Clark-distrusted by those who desired a Court active in protecting the liberties of Americans. ${ }^{103}$ Those desiring an active role for the Supreme Court in changing the social structure of the country were deeply disappointed by the Truman appointees. ${ }^{104}$ Typical of this group was Fowler Harper of Yale, who coauthored two articles focusing not on the work of the Court, but on the cases the Supreme Court refused to hear. The title of the first conveys the impatience: What the Supreme Court Did Not Do in the 1949 Term. ${ }^{105}$ The despair of a failed revolution was evident in many pieces, among them Eugene Gressman's The Tragedy of the Supreme Court. ${ }^{106}$

\section{b. Nonetheless, Academics Fret}

Despite the fact that the Court was doing very little to arouse broad popular disapproval during this long period, there nonetheless erupted a wide-ranging academic debate over the role of the Supreme Court, occasioned by fragmentation on the Court itself. C. Herman Pritchett placed the time of the Court's split to the 1941-1942 Term. "The [New Deal] battle being won, they broke ranks." 107 "[T] $]$ he Court began about 1941 to step up its production rate of dissents until previously unheard of levels of

103. Id. at 30-31

104. See Burton C. Bernard, Avoidance of Constitutional Issues in the United States Supreme Court: Liberties of the First Amendment, 50 MICH. L. REV. 261 (1951) (arguing for the Court to stop using avoidance techniques "when liberties of the First Amendment are threatened"); Freund, supra note 90, at 552 ("The question is not whether the courts can do everything but whether they can do something."); Fowler V. Harper \& Edwin D. Etherington, What the Supreme Court Did Not Do During the 1950 Term, 100 U. PA. L. REV. 354, 408 (1951) ("Like the previous term, the 1950 term disclosed the largest number of denials in 'important' cases to involve civil liberties ... under the First, Fifth, Sixth, Ninth, Thirteenth, and Fourteenth Amendments."). Fred Rodell expressed similar sentiments:

Chief Justice Vinson's take-it-easy Court heard about half as many cases a year as did

Chief Justice Hughes' hustling Court a mere decade before. Nor was this for lack of critical cases, of urgent issues begging for a hearing, and turned down.... [A]ll these questions and dozens like them, within the short space of two Court terms, were deemed by Vinson and company not worthy of decision-or perhaps too hot to handle. Nor could any power on earth then force the unjudging Justices to handle them.

FRED ROdell, Nine MEN: A POlITICAL HISTORY OF THE SUPREME COURT FROM 1790 TO 1955, at 15 (1955).

105. Fowler V. Harper \& Alan S. Rosenthal, What the Supreme Court Did Not Do in the 1949 Term-An Appraisal of Certiorari, 99 U. PA. L. REV. 293 (1950); see also Eugene Gressman, The Tragedy of the Supreme Court, NEw REPuBLIC, Sept. 3, 1951, at 10 (lamenting the same state of affairs).

106. Gressman, supra note 105; see also Bemard, supra note 104, at 261 ("The frequently criticized reluctance of the Supreme Court to consider complaints of unconstitutional governmental action is manifested in the utilization by the Court of various rules of avoidance of constitutional issues."); Dilliard, supra note 102, at 30 (expressing concern over the direction the Court would take after the elevation of Tom Clark to the bench because of Clark's role in the relocation of Japanese Americans during World War II).

107. PRITCHETT, supra note 47 , at 40 . 
disagreement were attained. ${ }^{\prime 108}$ The press seized on this, as well as the perceived hostile tone of some dissents. ${ }^{109}$ Writing in the New York Times Magazine, Thomas Reed Powell would observe, "Two characteristics of judicial conduct have attracted especial public notice. One is the recurring differences of opinion among the justices. The other is the manner in which some of these disagreements have been expressed." 110 The splintering of the Court led to inevitable stories focusing on the personalities and political proclivities of the Justices. ${ }^{11}$

Aided substantially by academics, the press explained to the public that the split was not along what were considered traditional conservative/liberal lines, but rather about the role of the Court. "[A] bench of nine, confronted by the problems of a culture in crisis[,] is bound to divide; and, since the stalwarts are no longer there to put their questions, the divisions will be along new lines." 113 Indeed, John Chamberlain, writing on the pages of $L i f e$, thought that the labels themselves now made less sense, particularly with regard to the Court. "When it comes to applying the fashionable terminology of 'liberal' and 'reactionary' to the present court," he explained, "the analyst at once gets into a semantic bog." 114 The conflict had little to do with politics and everything to do with one's conception of the role of the judiciary in a democratic society. Had these men been in the

108. Id. at xii. The Roosevelt Court also brought a sharp increase in the number of concurring opinions. Id. at 48.

109. See, e.g., id. at 25-26 (analyzing the number of Court dissents); Chamberlain, supra note 82, at 77 (noting that "the justices disagreed more often than they agreed for the first time in the court's history"); Pekelis, supra note 47, at 522 ("The Justices ... are hopelessly split."). The concern about the tone of opinions was heightened when disagreements between Justices Black and Jackson enupted in the public eye. For discussions of the Black-Jackson split, see PRITCHETT, supra note 47, at 26-29; and Schlesinger, supra note 82, at 201. With fundamental disagreements, the "intellectual squabbles" among the Justices often became "heatedly personal." Chamberlain, supra note 82, at 79. But not everyone believed that the tone of the opinions was "bad." Professor Powell wrote:

Such interchanges should not be taken more seriously by the readers than by the writers. Judges do not cease to be lawyers ... and lawyers are accustomed to spirited verbal combativeness without undue strain on personal relations.... [T] here is no occasion for public concern because some of the justices occasionally pelt each other with the shuttlecock of "gratuitous."

Powell, supra note 80, at 17.

110. Powell, supra note 80 , at 17.

111. See Eugene V. Rostow, Book Review, 56 YALE L.J. 1469 (1947); Chamberlain, supra note 82 ; Schlesinger, supra note 82.

112. Social scientists of the era began the practice of elaborate statistical tallying of Court votes in order to find ideological pairings. PRITCHETT, supra note 47, at 32-45 (analyzing the division of the Roosevelt Court); Frank, supra note 84, at 401-02 (measuring constitutional decisions from 1946 to 1950 against political concerns of the time); see also Chamberlain, supra note 82 , at $79,91-93$ (commenting that the tallying up of dissenting opinions had become an annual pastime of many, including Professor Pritchett, and continuing to describe the typical division of the Court); Powell, supra note 80, at 17, 44-45 (discussing the frequency of split decisions with dissents by Justice Roberts).

113. Hamilton \& Braden, supra note 47, at 1374.

114. Chamberlain, supra note 82 , at 79 . 
legislature together, most of them may have voted similarly. What they did on the Court was a different matter. The headline on Arthur Schlesinger's feature on the Supreme Court in Fortune hit the nail right on the head: "The Justices are not divided on political issues but on the understanding of their function." 115 And in the New York Times Magazine, Powell explained in greater detail:

The contrast is not one between competence and incompetence. Both rank high in intellectual competence. Nor is the contrast one between liberalism and conservatism in realms outside conceptions of the proper scope of the judicial function. The chief underlying difference is in conceptions of that function. Again roughly one may contrast a leaning for getting the result in the particular case as if it were a legislative choice with a leaning to respect the outlines and many of the details of an established legal system. ${ }^{116}$

Given academic discontent over the Court's failure to do more on the civil liberties front, the debate was over what the Court might do--or more accurately, how to justify what the Court might do. This was the problem of the "double standard." How could one countenance judicial activism in the area of civil liberties after the Court had abjured with regard to economic rights? At the end of the decade, Paul Freund would observe, "It requires no pedantic use of a calculating machine to discover that in the past fifteen years the Fourteenth Amendment has had very little impact on the regulation of economic affairs and very great impact on issues of procedure and civil liberties." 117 Similarly, Eliot Richardson would comment, "[T]he impression that the deference extended to economic regulation should be abandoned in the case of legislation affecting freedom of expressionindeed, that the Supreme Court has abandoned it - has become remarkably widespread." 118

115. Schlesinger, supra note 82 , at 73; see also id. at 201 ("[T]he clash of judicial personalities had transformed them from mere marginal divergences into a fundamental conflict over the proper function of the judiciary in a democracy.").

116. Powell, supra note 80, at 45; see also Noel T. Dowling, The Methods of Mr. Justice Stone in Constitutional Cases, 41 CoLuM. L. REv. 1160, 1164 (1941) (posing the question: "What part do the people want the courts, and especially the Supreme Court, to perform in the operations of our plan of government, whether the case in hand has to do with maintaining a balance between nation and state or protecting individuals against government, national or local?").

117. Freund, supra note 90 , at 534.

118. Richardson, supra note 90, at 47; see also PRITCHETT, supra note 47, at 92 ("The truth is that the Roosevelt Court has developed a double standard for guiding judicial review."); Herbert Wechsler, Stone and the Constitution, 46 ColUM. L. Rev. 764, 793 (1946) ("For it is the paradox of the period, if paradox it be, that new areas of constitutional protection were emerging even as the power to govern was being sustained."). 
"[I]s a double standard justified?" Freund wondered. ${ }^{119}$ Although for Freund the answer was yes, for many others the answer was no. ${ }^{120}$ Frankfurter was characteristically blunt: "Our power does not vary according to the particular provision of the Bill of Rights which is invoked." 121 So was Learned Hand:

I can see no more persuasive reason for supposing that a legislature is a priori less qualified to choose between "personal" than economic values, and there have been strong protests, to me unanswerable, that there is no constitutional basis for asserting a larger measure of judicial supervision over the first than over the second. ${ }^{122}$

Much more about what academics had to say in this debate later; for now what matters is that it was to this dispute over the role of the Court that the modern obsession can be traced. If a year need be picked, it was 1943. Two related events occurred in that year. The first was the Supreme Court's decision in West Virginia State Board of Education v. Barnette, ${ }^{123}$ striking down the compelled flag salute just four years after it had been upheld in Gobitis. Frankfurter's strident dissent in Barnette ${ }^{124}$ was not the first time the countermajoritarian difficulty hit the pages of the United States Reports, but it might have been the hardest and most voluble. "It cuts deep into one's conception of the democratic process .... If the function of this Court is to be essentially no different from that of a legislature ... then indeed judges should not have life tenure and they should be made directly responsible to the electorate."125 Following on the heels of Barnette was Henry Steele Commager's book on judicial review, Majority Rule, Minority Rights, which he dedicated to Frankfurter. Commager sought to correct what he perceived as a widespread view that American democracy meant protection of minority rights by the courts. "It is, needless to say, with the function of judicial review as a check upon democracy that we are concerned," Commager wrote. ${ }^{126}$ His conclusion was that "judicial review ... has been a drag ... upon democracy."127

119. Freund, supra note 90 , at 535 .

120. See id. at 545-57.

121. W. Va. State Bd. of Educ. v. Barnette, 319 U.S. 624, 648 (1943) (Frankfurter, J., dissenting).

122. Learned Hand, The Bill of Rights: The Oliver Wendell Holmes lectures 51 (1958).

123. 319 U.S. 624.

124. $I d$. at 646 .

125. Id. at 651-52 (Frankfurter, J., dissenting).

126. COMMAGER, supra note 48 , at 27.

127. Id. at 56. Commager also writes:

How can it be said that the problem of judicial review is the problem of democracy? A moment's reflection on the institution will clarify the statement. The function-and 
This criticism sounded just like Bickel's, yet came two full decades before The Least Dangerous Branch would see light. Commager's and Frankfurter's complaint made it necessary, even for those sympathetic to the Supreme Court's work, to respond to a debate set in countermajoritarian terms. ${ }^{128}$ Though the Court was doing little in the way of striking down laws, academic commentators started to fret over the problem. In 1952two years before Brown v. Board of Education-Arthur Sutherland and Eugene Rostow wrote influential articles whose very titles (The Supreme Court and the General Will and The Democratic Character of Judicial Review, respectively) evoked the concerns on the minds of many in the academy. ${ }^{129}$

\section{Brown v. Board of Education: 1954}

\section{a. Public Debate}

Then, in 1954, Brown v. Board of Education ${ }^{130}$ broke over the country like a storm. The first work of the Warren Court, chronologically and Id. at 40

effect - of judicial review is to give or deny judicial sanction to an act passed by a majority of a legislative body and approved by an executive. Every act adjudicated by the court has not only been ratified by a majority, but it has-in theory and we must suppose in fact-been subject to scrutiny in regard to its conformity with the Constitution. In support of every act, therefore, is not only a majority vote for its wisdom but a majority vote for its constitutionality.

128. For example, John Frank wrote:

[I]n a democracy there is a proper reluctance to leave unrestricted policy making to lifetime appointees.... This philosophy stems fundamentally from a basic belief in Democracy, from a conviction that the will of the people is morally entitled to be the law of the land except insofar as the Constitution pretty clearly restricts that popular will.

Frank, supra note 88, at 142,145; see also PRITCHETT, supra note 47, at 21 (warning that "the Supreme Court enjoys the privilege of becoming unrepresentative only at its peril, for methods of retaliation are readily available should the representative branches of government have cause to resort to them"); Bernard, supra note 104, at 263; Hamilton \& Braden, supra note 47, at 1356 ("To insist that five of a bench of nine be empowered to set aside the command of the two houses, approved by the President, is to set down a serious qualification upon the democratic process."); Richardson, supra note 90 , at 54 (stating that "[i]t was not with [this] understanding [of] the job of judges [being free to strike down the will of the majority] that they were made appointive and given life tenure"); Schlesinger, supra note 82, at 208 ("[T] he larger interests of democracy in the U.S. require that the Court contract rather than expand its power, and that basic decisions on all questions save the fundamental rights of political agitation be entrusted as completely as possible to institutions directly responsive to popular control."). But see Thomas Reed Powell, Authority and Freedom in a Democratic Society: Constitution, Legislatures, and Courts, 44 COLUM. L. REV. 473, 473 (1944) ("For any society that governs without courts could hardly in these days be regarded as democratic.").

129. See Eugene V. Rostow, The Democratic Character of Judicial Review, 66 HARV. L. REV. 193, 197, 203, 210 (1952); Arthur E. Sutherland, The Supreme Court and the General Will, 82 PROC. AM. ACAD. ARTS \& SCl. 169, 174 (1952-1953).

130. 347 U.S. 483 (1954). 
perhaps as a legacy, was the decision in Brown, declaring de jure racial discrimination in the public schools unconstitutional. Brown and its companion cases were a holdover from the Vinson Court; these cases had received national attention even as early as $1951 .{ }^{131}$ By the time the decision was rendered in 1954, the country was well ready for the Court's verdict.

Generally speaking, Brown was met with widespread approval, ${ }^{132}$ although the South found its way to loud and sustained defiance. ${ }^{133}$ Perhaps motivated in part by the controversy the Brown decision elicited in the South, group after group stepped forward-organized churches, ${ }^{134}$

131. For example, Ralph Bischoff wrote in 1957:

Not only is this attitude of deference and therefore delay clear in ... cases beginning with 1948 but it is also evident in the history of the segregation cases, both before and since the epoch-making decision of 1954 . From 1951 to 1954 the country was made aware of the very slow progress of the cases which were ultimately grouped together for decision... Briggs v. Elliott, Brown v. Board of Education, Belton v. Gebhart, Davis v. County School Board, and Bolling v. Sharpe.

Ralph F. Bischoff, One Hundred Years of Court Decisions: Dred Scott After a Century, 6 J. PUB. L. 411, 425 (1957); see also The Coming End of Jim Crow Schools, NEw REPuBLIC, Dec. 22, 1952, at 5 (stating that it would be inconceivable for the Court to affirm the separate but equal doctrine: "For all its weaknesses, the Truman Court is too sensitive to the public pulse to dodge the great verdicts of history.")

132. See Ross, supra note 50, at 606 ("Public opinion polls during the 1950 s consistently indicated that a large majority of Americans outside the South approved of Brown."); see also Bischoff, supra note 131, at 427 (stating that the Court's decisions give no cause to assert that it has abused the confidence, trust, and respect of the people); Thomas W. Christopher, Segregation in the Public Schools: Introduction, 3 J. PUB. L. 5, 6 (1954) (stating that the "momentous" decision represents the "shifting public opinion" toward a "different treatment for the Negro"); Charles Fairman, The Supreme Court, 1955 Term-Foreword: The Attack on the Segregation Cases, 70 HARV. L. REV. 83, 91 (1956) (stating that "a quickened national conscience was being reflected in the segregation decisions of the Supreme Court, and that Plessy v. Ferguson had become a very shaky precedent"); Arthur S. Miller, The Strategy of Southern Resistance, REPORTER, Oct. 10, 1958, at 20 (reporting on the South's resistance to the Brown decision, and stating that "[t]he South is employing the purposive use of law and legal machinery to further ends with which it knows much of the nation is not in sympathy"); The Supreme Court: The Temple Builder, TIME, July 1, 1957, at 12 (noting that "millions cheered the result," although lawyers were left with an "uneasy feeling" because it lacked legal grounds and had too much "sociological ballooning"). A Gallup poll administered within a week of the Brown decision indicated that $54 \%$ of those polled approved of the ruling, $41 \%$ disapproved, and $5 \%$ had no opinion. Regionally, respondents in the East ( $72 \%$ approved), West (65\% approved), and Midwest ( $57 \%$ approved) generally favored the decision, while those polled in the South did not $(24 \%$ approved and $71 \%$ disapproved). These results were compiled in response to the following question: "The United States Supreme Court has ruled that racial segregation in the public schools is illegal. This means that all children, no matter what their race, must be allowed to go to the same schools. Do you approve or disapprove of this decision?" 2 GEORGE H. GALLUP, THE GALLUP POLL: PUBLIC OPINION 1935-1971, at 1249-51 (1972).

133. See Morton J. Horwitz, The Warken COURT AND the PURSUIT of Justice 25 (1998) ("Reaction to the Brown decision was swift. As Richard Kluger recounts in his history of Brown, while much of the press outside the South greeted it with enthusiasm, many Southerners were shocked and angered.").

134. See ANNUAL OF THE SOUTHERN BAPTIST CONVENTION 56 (1954) (stating that Brown is "in harmony" with the constitutional guarantee of equal freedom to all citizens, and with the Christian principles of equal justice and love for all men); JOURNAL OF THE GENERAL 
educators, ${ }^{135}$ historians ${ }^{136}$ - to support the decision. There was approval not only on the merits, but also of the role of the Court in taking this step. ${ }^{137}$

Supporters of Brown relied heavily on two related arguments, neither of which, ironically, was to be found in the Court's decision. First, Brown was seen as an essential step in American efforts fighting the Cold War, for it undermined the hypocrisy of touting democracy while treating Negroes as second-class citizens. ${ }^{138}$ Second, Brown was seen as enhancing democracy generally. ${ }^{139}$ Representative of these arguments was the Kernel, the

CONVENTION OF THE PROTESTANT EPISCOPAl ChURCH 259 (1955) (expressing acceptance and support for the Supreme Court's ruling in Brown); Message by the Methodists, N.Y. TIMES, Sept. 13, 1956, at 17 (quoting a statement by the World Methodist Conference expressing its "active concern for those of any color or race who are suffering from political, economic, educational, social or religious discrimination, or segregation").

135. See Benjamin Fine, School Leaders Applaud Decision, N.Y. TIMES, May 18, 1954, at 14 (noting that leading American educators "applauded" the Brown decision).

136. See Historians Laud Court's Decision, N.Y. TIMES, May 18, 1954, at 17 (reporting that prominent historians called the decision "momentous" and a "milestone in American history").

137. See, e.g., Christopher, supra note 132, at 6 (stating that it is "of more than passing interest... that the Negro has made his greatest gains by way of the courts rather than legislatures"); Albert M. Sacks, The Supreme Court, 1953 Term-Foreword, 68 HARV. L. REV. 96, 96 (1954) (noting that the Brown decision "illustrates the functioning of the judicial process at its best").

138. Mary L. Dudziak, Desegregation as a Cold War Imperative, 41 STAN. L. REV. 61, 65 (1988) (citing the amicus brief filed in Brown by the Department of Justice, which argued that foreign policy concerns necessitated desegregation); see also MARY L. DUDZIAK, COLD WAR CIVIL RIGHTS: RACE AND THE IMAGE OF AMERICAN DEMOCRACY (2000) (describing the role that the Cold War played in pushing America toward greater civil rights for African Americans); Derrick A. Bell, Jr., Brown v. Board of Education and the Interest-Convergence Dilemma, 93 HARV. L. REV. 518, 524 (1980) (arguing that the Brown decision "cannot be understood without some consideration of the decision's value to whites, not simply those concerned about the immorality of racial inequality, but also those whites in policymaking positions able to see the economic and political advances at home and abroad that would follow abandonment of segregation"); id. (noting that Brown "helped to provide immediate credibility to America's struggle with Communist countries to win the hearts and minds of emerging third world peoples... [and] offered much needed reassurance to American blacks that the precepts of equality and freedom so heralded during World War II might yet be given meaning at home"); Michael J. Klarman, Rethinking the Civil Rights and Civil Liberties Revolution, 82 VA. L. REv. 1, 7 (1996) ("Brown is better understood as the product of a civil rights movement spawned by World War Il than as the principal cause of the 1960 s civil rights movement.").

139. See Howard W. Odum, An Approach to Diagnosis and Direction of the Problem of Negro Segregation in the Public Schools of the South, 3 J. PUB. L. 8, 13 (1954) ("[T] he pressure upon the South to reform its undemocratic actions must also be identified with the nation's midcentury high motivation for the reaffirmation of its basic democracy."); The Coming End of Jim Crow Schools, supra note 131, at 5 ("The democratic conscience of America is becoming increasingly aware of the unfairness and cruelty implicit in segregated school systems.... The demand for an end to the farce of segregation comes from the democratic heart of free men. No court decision can prevent the fulfillment of the aspirations of that heart."); The School Decision, CHRISTIAN CENTURY, June 2, 1954, at 662 ("[Brown] pushes along the effort to bring our democratic professions and our actual social practices into accord."); Fredric Wertham, Nine Men Speak to You, Nation, June 12, 1954, at 497, 498 ("With one stroke the Supreme Court reestablished in the consciousness of the people the fact that there is a majesty of democratic law and an inviolability of due process."); see also 102 CONG. REC. 4463 (1956) (statement of Sen. Humphrey) (" []$]$ f we persist in the course of denying people in America equal rights, we shall bring down upon our Nation the wrath of the world.... Frankly, we are talking about a matter 
newspaper at the University of Kentucky, which editorialized, "The ruling ... is one of the hardest blows dealt against communistic propaganda in many years. Unpleasant as it is to many Southerners, we are on the road to making the democratic principles embodied in our Constitution a fact.",140 In an extensive examination of Court-curbing during the Warren Court era, William Ross concluded, "Perhaps more than any other factor, the essential harmony between the Court's judicial opinions and the socio-political opinions of Americans may account for the failure of attacks on the Warren Court."141

In the South, of course, the Brown decision was vigorously attacked, ${ }^{142}$ but notably such criticism was typically not to the effect that the Court was interfering with popular will. Given loud national support for the decision, some support coming even from the South, ${ }^{143}$ most Southern rhetoric was

which goes to the safety and security of our Republic."); Erwin N. Griswold, Morrison Lecture, Address Before the State Bar of California (Oct. 9, 1958), in 4 MASs. L.Q. 98, 102 (1958) ("How can we expect to convince [the Communists] that our way of life deserves their support when we conduct ourselves as we have been doing?').

140. See Civic Groups Hail Anti-Bias Ruling, N.Y. TIMES, May 19, 1954, at 21 (quoting New York Representative Adam Clayton Powell who declared the decision "Communism's worst defeat" and "democracy's shining hour"); Court Said To End "A Sense of Guilt," N.Y. TIMES, May 18, 1954, at 18 ("This decision will open the way to relieving millions of white Americans of a sense of guilt which we have carried in us and at the least relieve ... some self-consciousness we have had even when practicing equality."); Eart B. Dickerson, Negro Rights and the Supreme Court, NATION, July 12, 1952, at 28 ("On the international scene American injustice to the Negro has propaganda value for the Kremlin and must therefore be condemned."); Historians Laud Court's Decision, supra note 136 (quoting Harvard Professor of History Arthur M. Schlesinger Sr., who stated that "[t]he decision will be a very great aid in clarifying to the world our conception of democracy"); Segregation and Silence, NEWSWEEK, May 24, 1954, at 26 (asserting that segregation, the symbol of inequality, once a "weapon of world communism," has been "shattered" by Brown).

141. Ross, supra note 50, at 604 ("As in previous eras, the Court remained roughly consonant with the temper of the times, even though many of its decisions offended significant segments of the population" (citing William G. Ross, A MUTED Fury: PoPUlists, Progressives, and LABOR UNIONS CONFRONT THE COURTS, 1890-1937, at 317 (1994)).

142. Reactions ranged from unhappy resignation and calls for calm, to outward defiance. Compare Harry S. Ashmore, Varied Patterns, NATION, May 29, 1954, at 456 (remarking that major Southern newspapers generally "accepted the new dispensation as something that must be lived with"), Talmadge Urges Georgians To Be Calm, ATLANTA CONST., May 18, 1954, at 9 (stating that Georgia Governor Talmadge "urge[d] all Georgians to remain calm and resist any attempt to arouse fear or hysteria"), and William S. White, Russell Demands Curbs on Use of Court as "Tool," ATLANTA CONST., May 18, 1954, at 1 (quoting Louisiana Senator Russell Long, who while disagreeing with the decision, stated that his "oath of office require[d] [him] to accept it as the law"), with Ashmore, supra, at 456 (citing the Jackson, Mississippi Daily News as having "roared [in] defiance of the court" and referred to the "blood-stained Southern soil"), Governor Stands Pat on Schools, ATLANTA CONST., June 1, 1955, at 1 (quoting Governor Talmadge as stating that "[a]s long as I am governor, and as long as the State of Georgia operates its schools, that precept [of segregation of the races] will stand, the federal court to the contrary, notwithstanding"), and White, supra (quoting Mississippi Senator James O. Eastland as stating that "[t]he South will not abide by nor obey this legislative decision by a political court").

143. See LuCas A. POWE, JR., The Warren COURT AND AMERICAN POlitics 36, 99-101 (2000) ("In 1954 the South did not speak with one racist voice, as it so often had in the past, and the southern urban press was surprisingly conciliatory ...."); Ruling Tempers Reaction of South, 
defensive, acknowledging the region's minority status. One commentator in the late 1950s made precisely this point: "Insofar as integration is the basis for attacking the Court, there is no responsible opinion to the effect that the Court's position does not reflect the attitude of a decisive popular majority." 144 Herman Pritchett, perhaps the political scientist most attuned to the Court's work, explained that states' rights arguments have often been the last refuge of minority protest, and this instance was no different. ${ }^{145}$ Thus, the Southern Manifesto, a statement of opposition to school desegregation by ninety-six Southern members of Congress, explicitly recognized the minority status of the Southerners, reaching out to the national majority not on the merits, but on the issue of whether the Supreme Court should effect this change:

Even though we constitute a minority in the present Congress, we have full faith that a majority of the American people believe in the dual system of government ... and will in time demand that the reserved rights of the states and of the people be made secure against judicial usurpation. ${ }^{146}$

Southerners also claimed that the Supreme Court had ignored the "correct" interpretation of the Constitution. Immediately after Brown was decided, Senator Richard Russell of Georgia stated, "Ways must be found to check the tendency of the court to disregard the Constitution and the precedents of able and unbiased judges to decide cases solely on the basis of the personal predelictions of some of its members as to political,

supra note 49 (reporting Kentucky Govemor Wetherby's statement that the Brown decision was "one of the most far-reaching of our times" and that state officials would "do whatever was necessary to comply with the law"); see also Reaction to High Court Decision: Hailed as Triumph for Democracy by Some, Tragic by Others in South, NASHVILLE TENNESSEAN, May 18, 1954, at 1 (quoting the Kansas City Star's statement that "the court's ruling was the only one it could make").

144. J. Patrick White, The Warren Court Under Attack: The Role of the Judiciary in a Democratic Society, 19 MD. L. REV. 181, 196 (1959).

145. See generally C. HeRman PRITCHETT, CONGRESS Versus the SUPREME COURT 195760 , at 18 (1961) (noting that Southerners opposed to the segregation ruling based their attack on the Court on the historic claims of states' rights); James F. Byrnes, The Supreme Court Must Be Curbed, U.S. NEWS \& WORLD REP., May 18, 1956, at 58 (suggesting the "frightening ... consequences" of the Court's trend to "destroy the powers of the 48 states"); Albert Riley, Candidates Vow To Keep Barriers, ATLANTA CONST., May 18, 1954, at 10 (quoting Georgia Lieutenant Governor Marvin Griffin, who called Brown "unfortunate" but "not surpris[ing], as the meddlers, demagogues, race-baiters and Communists in the United States are determined to destroy every vestige of states rights").

146. Text of 96 Congressmen's Declaration on Integration, N.Y. TIMES, Mar. 12, 1956, at 19; see also H.R. 174-554d, 1957 Ga. Laws 553, 560 ("However much citizens of other states may approve and applaud these decisions, they dare not embrace the theory upon which they are based nor the fallacies there contained lest they themselves by the application of the same theory and fallacies bring ... destruction to their liberties."). Indeed, reappearance of the states' right argument served to underscore the minority status of the Southern dissenters. 
economic and social questions." 147 The Southern Manifesto condemned the Court for "substitut[ing] naked power for established law" and the imposition of "personal predilections of public officeholders," 148 themes echoed by many, including Sam Ervin ${ }^{149}$ and James Byrnes. ${ }^{150}$

Cries of defiance were rampant. James Eastland was blunt: "The South will not abide by nor obey this legislative decision by a political court."151 Typical were interposition resolutions enacted by the states of Georgia, Virginia, and Alabama. ${ }^{152}$ Defiance was defended as the proper response to an unlawful decision, as this editorial from the Richmond News Leader (as reported in the London Economist) made clear:

That inept fraternity of politicians and professors known as the United States Supreme Court chose to throw away the established law. These nine men repudiated the Constitution, spat upon the tenth amendment, and rewrote the fundamental law of this land to suit their own gauzy concepts of sociology. If it be said now that the South is flouting the law, let it be said to the high court: you taught us how. ${ }^{153}$

Ultimately, it would require sending federal troops into Little Rock to restore order and demonstrate national resolve.

147. White, supra note 142.

148. 102 CONG. REC. 4460 (1956) (statement of Sen. Walter F. George). Of course, the Supreme Court made is easy for them: The Brown decision itself essentially ignored Plessy, conceded that the legislative history of the Fourteenth Amendment yielded no clear authority for the decision, and depended instead on the importance of education and upon sociological studies as to the impact of segregation on learning.

149. Sam Ervin, speaking of Southern officials, merely mused:

They cannot grasp how it is that their oaths to support the Constitution compel them to accept what Chief Justice Warren and his associates said about the Fourteenth Amendment; whereas the oaths of Chief Justice Warren and his associates to support the Constitution permit them to reject what their judicial predecessors said on the same subject.

Sam J. Ervin, Jr., The Case for Segregation, Look, Apr. 3, 1956, at 33

150. See Byrnes, supra note 145, at 53 (explaining how the Court "invad[ed] the legislative field" and decided the case not according to legal precedent but according to sociology); Ervin, supra note 149, at 33 (asserting that the Court "repudiated upon the basis of psychology and sociology the interpretation placed upon the Constitution in general and the Fourteenth Amendment in particular during those preceding 86 years"); see also Ralph T. Catterall, Judicial Self-Restraint: The Obligation of the Judiciary, 42 A.B.A. J. 829, 833 (1956) ('Never before have the personal predilections and moral certainties of the Justices ridden so rough-shod over the text of the written Constitution.").

151. White, supra note 142.

152. See, e.g. H.R. 174-554d, 1957 Ga. Laws 553, 560.

153. Dixie Rejoins the United States, ECONOMIST, Sept. 24, 1955, at 1036-37. 


\section{b. Academic Silence}

In the face of this loud, fierce national debate, academic critics of the Court were largely silent. ${ }^{154}$ Superficially, it is not that difficult to explain the silence. Given the source and nature of public criticism of Brown (not to speak of the broader public approval), academics were understandably reluctant to enter the arena. As Erwin Griswold said in 1958, "With such a hue and cry being raised, one should be very careful that he does not join it, and that he does not create the impression that he is joining it." ${ }^{, 155}$ Although public opposition to the Court was more widespread by the late 1950s, the company was not necessarily all that much better. For example, in 1958, the National Conference of State Chief Justices published a report extremely critical of the Supreme Court. University of Chicago Law Professor Philip Kurland had helped the State Chief Justices write their report (issued somewhat unfortunately in the midst of the Little Rock crisis) and rose to defend it, nonetheless worrying that it "gave aid and comfort to the enemy," in light of the "warm greetings of brotherhood from the Southern demagogues and the paeans of praise from the American witch-hunting fraternity." 156

But far more important, Brown was hardly seen among many academics at the time as signaling a new role for the Supreme Court. This was evident from a conference held at Harvard in 1955 to mark the 200th anniversary of the birthday of John Marshall, a conference attended by legal luminaries from around the world. Although the activist role of the judiciary was recognized as a possibility and debated, it was a rather sterile debate sharing none of the passion that would mark legal scholarship in a few short years. Typical were Felix Frankfurter's musings introducing the conference. Frankfurter told a story-one remarkably lacking in prescience of what was just ahead - of how Theodore Roosevelt almost did not appoint Holmes to the Supreme Court because Holmes had himself questioned whether Marshall was an original thinker:

As though one should look among even the greatest of judges for what Holmes called "originators of transforming thought." I venture to suggest that had they the mind of such originators, the

154. Obviously, there were academics who were quick to praise the opinion. See, e.g., Sacks, supra note 137. The focus here, of course, is on criticism.

155. Griswold, supra note 139, at 101. In further explanation of why the academy was reluctant, Griswold stated: "The task of the person who seeks to give constructive professional commentary and criticism is thus made a very difficult one, for anything that he may write is susceptible to misuse by such irresponsible critics of the Court and its work." Erwin N. Griswold, The Supreme Court, 1959 Term-Foreword: Of Time and Attitudes-Professor Hart and Judge Arnold, 74 HARV. L. REV. 81,82 (1960).

156. Philip B. Kurland, The Supreme Court and Its Judicial Critics, 6 UTAH L. REV. 457, 459 (1959). 
bench is not the place for its employment. Transforming thought implies too great a break with the past, implies too much discontinuity, to be imposed upon society by one who is entrusted with enforcing its law. ${ }^{157}$

Still disenchanted with the Court's performance throughout the 1940s, the bulk of the conference was a discussion of what judges should do, not what they were doing; Brown received little mention; and anxiety was expressed by some about the judges doing too little. ${ }^{158}$

Indeed, it is almost comical to read the work of authors caught flatfooted still fighting the battles of 1937 when the activism of the Warren Court was just beginning. These scholars were still focused on earlycentury liberal discontent with the Court's interference with economic regulation, and praised the Court for self-restraint, at a time when its activism on an entirely different front-racial equality and civil rights and liberties - was on the rise. Professor Fred Cahill's 1952 book Judicial Legislation focused on the New Deal transformation and understandably missed entirely what was about to occur. ${ }^{159}$ More embarrassing was Bernard Schwartz's lengthy volume The Supreme Court: Constitutional Revolution in Retrospect. Schwartz's "revolution," one he lauded, consisted of the adoption by the Court since 1937 of "a consistent basic philosophy... [of] the doctrine of self-restraint or deference to the legislative will."160 Taking a 1937 "liberal" perspective, Schwartz was cautious of calls for a more activist judiciary:

[I]f there was one principle that nineteenth-century liberals agreed upon, it was that of the primacy of legislative power. To them, it was the elected representatives of the people, not an irresponsible judicial organ, who were endowed with primacy in the governmental structure.... [I]s this not the proper distribution of governmental power in a representative democracy? ${ }^{161}$

157. Felix Frankfurter, John Marshall and the Judicial Function, in GOVERNMENT UNDER LAW 6, 9 (Arthur E. Sutherland ed., 1956) (emphasis added).

158. See William H. Hastie, Judicial Method in Due Process Inguiry, in GovernMENT UNDER LAW, supra note 157, at 326, 359 (commenting that in recent cases judges have used "too much restraint").

159. FRED V. CAHILL, JR., JUDICIAL LEGISLATION 149 (1952) (arguing that the need for a new theory of judicial function arose as a result of the emergence of the modern state and the judicial questions presented by the exercise of governmental power); see also PAUL G. KAUPER, FRONTIERS OF CONSTITUTIONAL LIBERTY 41 (1956) (noting that "[i]t needs no special astuteness to observe that we have now passed the period of high tide in the protection of the First Amendment freedoms and that a period of recession has set in").

160. SCHWARTZ, supra note 49 , at 368 .

161. Id. at 371 . 
Reviewing Schwartz's book, Arthur Selwyn Miller aptly said it all: “As it is, a book published on June 20,1957, was in need of major revision the day it was released." 162

\section{The "Communist" Decisions: 1957}

\section{a. The Court in Trouble}

Schwartz's book was out-of-date the day it was released because as it came into print the Supreme Court was deciding the Communist cases. ${ }^{163}$ "[J]ust as the controversy over the Supreme Court was beginning to decline in 1956, another segment of public opinion was aroused by other circumstances to attack the nation's highest tribunal." ${ }^{\text {"64 }}$ During the 1956 Term, the Supreme Court decided upwards of ten cases dealing with the Communists or Communist sympathizers, four of them on one day: June $17,1957 .^{165}$ The cases, among other things, limited the scope of congressional investigations, curtailed the power of states to regulate bar admissions and subversive activity generally, narrowed the breadth of the Smith Act, ${ }^{166}$ and included the notorious Jencks decision requiring the

162. Arthur S. Miller, Book Review, 6 J. PUB. L. 522, 526 (1957) (reviewing SCHWARTZ, supra note 49).

163. Even after the 1957 decisions, the direction of the Court was not altogether clear. As Robert McCloskey asked:

The great question for a student of contemporary constitutional history is this: can the Court rest satisfied with the important but subsidiary place in government which the main course of its post-1937 decisions seemed to imply? ... [T] he Court is currently standing on the banks of the Rubicon.... If the Term is to be judged by the noise it evoked and the public bolts that have been hurled from certain high circulation quarters, it must be concluded that the river has already been crossed .... But is there actual fire behind these clouds of public smoke?

MCCLOSKEY, supra note 63, at 160-61.

164. White, supra note 144 , at 188 .

165. See Service v. Dulles, 354 U.S. 363 (1957) (reversing the Secretary of State's discharge of a foreign service officer, which had been based on an FBI investigation revealing his communication of secret military plans to a pro-Communist magazine); Yates v. United States, 354 U.S. 298 (1957) (reversing the convictions of defendants charged with conspiring to advocate and teach the forcible overthrow of the U.S. government and to organize the Communist Party in violation of the Smith Act on the grounds that "organize" referred only to creation of a new organization and not to already existing organizations); Sweezy v. New Hampshire, 354 U.S. 234 (1957) (reversing the conviction of a witness who refused to answer a question regarding the Progressive Party during an investigation of subversive activities); Watkins v. United States, 354 U.S. 178 (1957) (holding that the House Un-American Activities Committee could not require a witness admitting involvement with the Communist Party to name his associates, even without invoking his Fifth Amendment rights).

166. See, e.g., Konigsberg v. State Bar, 353 U.S. 252 (1957) (reversing the California Bar Examiner's decision to refuse an applicant's admission because he had ostensibly failed to show good moral character by refusing to respond to questions regarding past and present membership in the Communist Party); Schware v. Bd. of Exam'rs, 353 U.S. 232 (1957) (reversing the New Mexico Bar Examiner's denial of an applicant who was unable to show good moral character due to his use of aliases and his past membership in the Communist Party); Cole v. Young, 351 U.S. 
government to turn over investigative material the defense might need to cross-examine government witnesses. ${ }^{167}$

While the Daily Worker cheered, ${ }^{168}$ concern about the Supreme Court was heard from many other corners of the country. ${ }^{169}$ Commented Representative Howard W. Smith, "I do not recall any case decided by the present Court which the Communists have lost."170 A committee of the American Bar Association issued a scathing report accusing the Supreme Court of undermining national security, which in turn evoked a brouhaha within the ABA, as well as the resignation from the ABA of the Chief Justice. ${ }^{171}$ The flames were fanned by segregationists still angry at Brown, who finally had found an issue on which there was broader national support. In a sense, the Communist decisions created an anti-Court coalition broad enough to claim majority status. "Southern Congressmen, having failed in their initial effort to mobilize anti-court sentiment ... were quick to perceive that their basic purpose of discrediting the Supreme Court would be served whether the issue was undue concern for civil liberties or softness to communism or states' rights."

536 (1956) (reversing the dismissal of a federal government employee based upon his "sympathetic association" with an allegedly subversive organization); Slochower v. Bd. of Educ., 350 U.S. 551 (1956) (reversing the dismissal of a college professor, who had been dismissed without a hearing based upon his invocation of the Fifth Amendment in response to inculpatory questions regarding membership in the Communist Party); Pennsylvania v. Nelson, 350 U.S. 497 (1956) (holding that the Smith Act, which prohibits the knowing advocacy of the overthrow of the U.S. government by force or violence, suspends the enforceability of the majority of the state antisedition statutes).

167. Jencks v. United States, 353 U.S. 657 (1957) (reversing the conviction of a labor union officer for filing a false non-Communist affidavit with the NLRB and holding that the labor union officer was entitled to examine FBI reports made by government witnesses).

168. See, e.g., 9 Win Retrial in Smith Act Ruling, DAILY WORKER, June 18, 1957, at 1; Cheer High Court Liberty Ruling, DAILY WORKER, June 19, 1957, at 1; A Milestone for Democracy, DAILY WORKER, June 19, 1957, at 1 . The articles and editorials themselves reported support for the decisions as well. See Hails New Verdict as Spur to Hope, DAILY WORKER, June 18, 1957, at 1 (noting the "general elation" among democratic-minded citizens over the June 17, 1957 decisions by the Supreme Court); A Milestone for Democracy, supra ("[T]he decisions mark the definitive ending of the McCarthyian era in American life.").

169. For a full discussion of the Red Monday cases and reaction to them, see SABIN, supra note $97, \mathrm{ch} .8$.

170. David Riesman, New Critics of the Court, NEw REPUBLIC, July 29, 1957, at 9; see also Byrnes, supra note 145, at 58 (referring to the "frightening" consequences of the Court's decisions to "destroy the powers of the 48 States" in the area of Communist activities).

171. See Report of Special Committee on Communist Tactics, Strategy and Objectives, 84 ANN. REP. A.B.A. 607 (1959); see also Robert J. Donovan, Attorney General Backs A.B.A. in Stand on Court, N.Y. HERALD, Apr. 23, 1959, at 8 (reporting Chief Justice Earl Warren's resignation from the $A B A$ following the organization's criticism of the national security and communism cases). See generally POWE, supra note 143, at 99-101 (describing actions undertaken by the $\mathrm{ABA}$ attacking the Court that ultimately led Warren to resign his membership).

172. White, supra note 144, at 189. The extent to which Southerners used the Communist decisions as a wedge is evident from this seemingly out-of-place remark by Strom Thurmond about the decision in Cooper v. Aaron: "[N]o one will rejoice more from this decision than Nikita S. Khrushchev and his cohorts." Senators Assail and Praise Court, N.Y. TIMES, Sept. 30, 1958, at 
During this period the Court faced its most serious institutional attack since 1937 (and indeed the last serious attack it has faced since). ${ }^{173}$ Senators William Ezra Jenner and John Marshall Butler introduced a legislative plan to curtail the jurisdiction of the Supreme Court. ${ }^{174}$ Ultimately Congress adopted just one watered down provision of the bill, modifying the Jencks rule. ${ }^{175}$ But this vote followed lengthy hearings, vitriolic floor debate, and a number of close votes. ${ }^{176}$ Eisenhower spoke up to defend the Court, but even his support was tepid, conceding that among the decisions were "some that each of us has very great trouble understanding."177

The hearings over the Jenner-Butler Bill, and the countless letters put into the record of those hearings, reveal widespread concern about the Communist conspiracy but perhaps equal concern over the role the Supreme Court was playing in political life. ${ }^{178}$ Those who opposed the 1956 Term decisions repeatedly spoke of the Court exceeding its proper role by interfering with the legislative function. The head of the National Association of Attorneys General referred to the "fiat of five appointed justices." ${ }^{179}$ Similarly representative was the Columbia (South Carolina)

22; see also PRITCHETT, supra note 145 , at 120 ("To a very considerable degree the legislative opposition to the Court's security decisions was recruited from among southern members of Congress whose main concern was retaliation for the Court's segregation ruling."); What the Court Did, DAILY WORKER, June 20, 1957, at 5 (quoting Louisiana Congressmen George W. Andrews, who stated that there are two groups that "can't lose" a case before the Court-the Communists and the NAACP).

173. See generally PowE, supra note 143, at 99-102 (describing widespread criticism of the Court for the Communist decisions).

174. A Bill To Limit the Appellate Jurisdiction of the Supreme Court in Certain Cases, S. 2646, 85th Cong. (1957). Ironic, also, for just three years before 1954, Butler had recommended legislation to protect the Supreme Court from just this sort of attack.

175. See Philip B. Kurland, Politics, The Constitution, and the Warren Court 28 (1970) (arguing that the statute actually "did more to bulwark than to limit the Jencks ruling").

176. See Anthony Lewis, 4I-40 Senate Vote Kills Bills Aimed at Supreme Court, N.Y. TIMES, Aug. 22, 1958, at 1 (reporting the defeat of the proposed Jenner-Butler Bill in the Senate by a single vote, 41-40, with twenty-seven Democrats and fourteen Republicans against the bill).

177. William S. White, President Asks Respect for Court, Backs Rights Plan as "Moderate," N.Y. TIMES, June 27, 1957, at 10.

178. For example, one newspaper editor expressed the following views when testifying before Congress:

In the past year many hundreds of thousands of words have been printed about the recent decisions of the Supreme Court, and, as a result, there has been a general awakening throughout the country by the American public that not only has this Court continued to hand down decisions favorable to our enemy, the Communists, but that this Court has anrogantly usurped the legislative activities of the people's elected representatives in Congress, until now the Supreme Court has become the "third" House of Congress.

Limitation of Appellate Jurisdiction of the United States Supreme Court: Hearings on S. 2646 Before the Subcomm. To Investigate the Administration of the Internal Security Act and Other Internal Security Laws, 85th Cong. 287 (1958) [hereinafter Jenner-Butler Hearings] (statement of Kent H. Courtney, Editor, Independent American).

179. Lawrence E. Davies, Law Group Head Hits High Court, N.Y. TimES, June 25, 1957, at 1. 
paper the State: "The Court has usurped the power of the Congress, the State appellate courts and the juries of the States. In the exercise of dictatorial powers the difference between the Kremlin and the Supreme Court is that the Kremlin is composed of 11 men and the Supreme Court only 9." 180

Despite the controversy, the Supreme Court emerged from the period largely unscathed. Herman Pritchett, in his work Congress v. the Supreme Court 1957-1960 speculated as to several possibilities for the quieting of the storm. First, as in 1937, strong support for the Supreme Court and the rule of law served to defeat the attacks. ${ }^{181}$ Second, the attackers may have been hurt by the nature of their allies: Segregationists jumping on (or driving) the anti-Court bandwagon did not help the cause. ${ }^{182}$

But third, and perhaps most interesting, the Supreme Court tempered its prior positions in a series of decisions that might be called a second "switch in time," at least creating the appearance that it was backing away from the earlier controversial decisions. ${ }^{183}$ As Mark Tushnet has explained:

[T] he Court retreated-or so it seemed... [T] insisted that it had not changed course but said that the earlier cases were distinguishable on various grounds.... Nonetheless, many commentators were skeptical of the majority's claims, particularly because the later cases were decided over strong dissents by the

180. Riesman, supra note 170 , at 11 ; see also Jenner-Butler Hearings, supra note 178 , at 113 (statement of R. Carter Pittman) ("Nine men in black robes [rode] herd over the Congress and the people."); id. at 168 (statement of the Honorable William Old, Missouri Circuit Court Judge) ("[I]t is now clearly apparent, from a long list of revolutionary decisions by the Supreme Court, headed by Chief Justice Warren, that the Court is determined to destroy our dual system of government under the Constitution, and create, by usurpation and encroachment, a judicial oligarchy of unparalleled proportions."); id. at 246 (statement of W.E. Michael) ("This usurpation of power, without constitutional authority, not only relegates to subordinate positions the legislative and executive branches, but has the effect of destroying the sovereignty of the individual States, their constitutions and courts, by creating a highly centralized Federal Government headed by a supercourt."); Arthur E. Sutherland, Jr., The Supreme Court, 1956 Term-Foreword: The Citizens' Immunities and Public Opinion, 71 HARV. L. REV. 84, 85, 87 (1957) ("If joumalistic comment reflects popular opinion, a large number of Americans are thinking of this year 'as the time the Supreme Court went wrong on all those Communist cases." (citations omitted)).

181. PRITCHETT, supra note 145, at 119 (arguing that the Court "was protected by the respect which is so widely felt for the judicial institution in the United States").

182. Id. at 120 (observing that the segregationists, "[u]nable to muster a majority in Congress[,] . . sought a more effective expression of their antagonisms by joining in the hue and cry against the security nulings").

183. Id. at 121 (" $[T]$ he Court itself contributed to the defeat of the anti-Court legislation by subsequent moderation of the position taken in some of its controversial decisions."). 
liberal core of the Warren Court ... who insisted that the Court was effectively repudiating the precedents. ${ }^{184}$

Thus, perhaps as it had in the New Deal, the Court ducked controversy by changing direction, or at least-in this instance-by appearing to do so until the storm had quieted.

\section{b. Academic Crescendo}

Academics also came to howl at the Supreme Court in 1957, but the academy's concern was different. The difficulty, remarkably, was Brown, and what $i t$ portended about judicial review. The startling beginning of the debate was Learned Hand's call to the podium at Harvard Law School to deliver the 1957 Holmes Lectures. ${ }^{185}$ Hand, an old-time Progressive and the nation's "most revered" judge, ${ }^{186}$ spoke at the end of his long career. Hand's message, clouded by his usual eloquent but somewhat opaque prose, ${ }^{187}$ was one of profound skepticism about the propriety of judicial activism, if not judicial review altogether. ${ }^{188}$ Hand's talk was followed the next year by the Holmes Lectures of Professor Herbert Wechsler of the Columbia Law School. Wechsler expressed greater comfort than Judge

184. Mark Tushnet, Introduction to THE WARREN COURT IN Historical AND POLITICAL PERSPECTIVE 6 (Mark Tushnet ed., 1993).

185. In the academic brawl that ensued, many commentators pinpointed the Hand and Wechsler lectures as the starting point. See, e.g., Jan G. Deutsch, Neutrality, Legitimacy, and the Supreme Court: Some Intersections Between Law and Political Science, 20 STAN. L. REV. 169, 170 (1968) ("The starting point for the recent debate [regarding judicial review] has been Judge Hand's eloquent Holmes Lectures.... Professor Wechsler's essay on neutral principles, by rooting the power of judicial review in the text of the Constitution itself, attempts to slay the ghost of judicial usurpation raised by Hand."); Louis Henkin, Some Reflections on Current Constitutional Controversy, 109 U. PA. L. REV. 637, 651 (1961) ("Perhaps Judge Hand began the current round [in the debate over the role of the Court] in his rare incursion into the academic universe."); Robert G. McCloskey, The Supreme Court, 1961 Term-Foreword: The Reapportionment Case, 76 HARV. L. REV. 54, 65 (1962) ("Outside the Court, the dialogue was at length propelled into its present, active phase by Judge Learned Hand."); Arthur Selwyn Miller, Book Review, 9 How. L.J. 188, 188 (1963) (reviewing BICKEL, supra note 16) (noting that Hand's inquiry into the nature of judicial review in a democracy triggered a debate among commentators).

186. GERALD GUNTHER, LEARNED HAND 653 (1994) .

187. See Griswold, supra note 139, at 104 (remarking that the actual message in Hand's lectures was "far from clear"); Eugene V. Rostow, The Supreme Court and the People's Will, 33 NOTRE DAME L. REV. 573, 584 n.14 (1958) (characterizing Hand's argument as "a delight to read, but hard to parse").

188. See GUNTHER, supra note 186, at 655 ("Hand insisted that because their power rested only on the need to prevent the 'collapse' of the constitutional system, judges should use this power only in truly necessary situations."); Barry Friedman, Neutral Principles: A Retrospective, 50 VAND. L. REV. 503, 510 (1997) ("Any such interference with the operations of legitimate democratic government constinuted the Supreme Court, in Learned Hand's view, as a 'third legislative chamber."). Anthony Lewis referred to Hand as "[t]he foremost exponent" of the view that "the Court has too broadly exercised its great power." Anthony Lewis, The Supreme Court and Its Critics, 45 MINN. L. REv. 305, 312 (1961). 
Hand with the propriety of judicial review, but followed him in criticizing its use by the Warren Court. ${ }^{189}$ A target of both Holmes lecturers was Brown, which Hand and Wechsler suggested was somehow lacking in legitimacy. ${ }^{190}$ Wechsler in particular stumbled over the decision, unable to justify it, but all the while claiming agreement.

Following the Holmes Lectures, the dam of academic criticism of the Court burst wide-open. The stated reason for going public was that there had been an unfortunate lack of critical appraisal of the Supreme Court's work in responsible quarters. As Henry Hart wrote in his Harvard Foreword in 1959, "[N]either at the bar nor among the faculties of the law schools is there an adequate tradition of sustained, disinterested, and competent criticism of the professional quality of the Court's opinions."191 Authors of the Harvard Forewords quickly stepped in to fill the gap, as did the Supreme Court Review, which began publishing at this time under the guidance of Professor Philip Kurland. ${ }^{192}$

189. See Herbert Wechsler, Toward Neutral Principles of Constitutional Law, 73 HARV. L. REV. 1, 6 (1959) ("For me as for anyone who finds the judicial power anchored in the Constitution, there is no such escape from the judicial obligation; the duty cannot be attenuated in this way.").

190. Wechsler's main criticism of Brown was that it was not explainable by neutral principles. See HERBERT WeCHSLER, Toward Neutral Principles in Constitutional Law, in PRINCIPLES, POLITICS, AND FUNDAMENTAL LAW 3, 47 (1961) ("Given a situation where the state must practically choose between denying the association to those individuals who wish it or imposing it on those who would avoid it, is there a basis in neutral principles for holding that the Constitution demands that the claims for association should prevail?"). Laura Kalman and Neil Duxbury both indicate that Wechsler's criticism was of the reasoning of Brown, and not the result. See NEIL DUXBURY, PATTERNS OF AMERICAN JURISPRUDENCE 272 (1995); KALMAN, supra note 2 , at 34. This was undoubtedly right to the extent Wechsler expressed his admiration for the result. See infra notes 447-448. But the distinction likely was a little fine for the public to follow. Hand's criticism of Brown focused on the Court's "impermissible second guessing of legislative choices." Kalman described how Hand "injected criticism of Brown into his 1958 Holmes Lectures at the last minute and ... would have accepted Brown had he been allowed to interpret it broadly," but that Frankfurter

convinced Hand that "the somewhat opaque Brown opinion ... was an education case and that the permissibility of racial discrimination in other areas had to be decided by context-specific, case-by-case balancing analysis." . . Under Frankfurter's hammering, Hand concluded that the Court "had not meant to propound an absolute rule against racial inequality but instead engaged in its own reappraisal of legislative judgments."

KALMAN, supra note 2, at 33.

191. Hart, supra note 43, at 125; see also Griswold, supra note 155, at 81-82 ("Our Supreme Court Justices are isolated in a marble palace in Washington.... We have no tradition of friendly intra-profession criticism, and very little means for making such criticism available if it were in our tradition.... What we have sorely needed is more and better professional commentary and criticism, based on understanding and respect and designed to assist the Court with its great and difficult task in our constitutional system of govemment.").

192. The first volume of the Supreme Court Review, published by the University of Chicago Law School, appeared in December 1960. Lewis, supra note 188, at 320 \& n.84; see also id. at 319-20 (commenting on the proliferation of professional commentary on the Supreme Court's work in the early 1960s). 
The "new" critics of the Court, as Anthony Lewis would call them, ${ }^{193}$ made a valiant, but futile, effort to draw a line between themselves and the anti-Court rantings around them. ${ }^{194}$ Thus, Bickel would attempt to distinguish the "deafening, interminable" "shouting match that the segregationists and security-mongers engage in" from the "muted, constant, and timeless...effort, old as the Court itself, to subject to critical professional re-examination the nature of the Court's function and its performance." 195 Yet it was naive for academic critics like Bickel to think they could sustain the wall of separation between themselves and the howling masses. Soon enough their debate had spilled into the public eye. As U.S. News \& World Report observed in 1963, itself a bit late, "What is coming into the foreground now ... is criticism of the Court from a new and powerful source-recognized authorities in jurisprudence. ${ }^{, 196}$ Coming with a vengeance, one might add. Throughout the decade of the 1960 s, academics played prime-time roles in periodicals of public opinion such as the New York Times Magazine, the New Republic, and the Saturday Evening Post. ${ }^{197}$ Referring to Hand's lecture, Arthur Selwyn Miller

193. Id. at 319. Perhaps the most unique development was the extent to which the judiciary joined the academic critics in attacking (and defending) the Supreme Court. Judges, it seems, were giving speeches and writing articles for the popular and law review press in unprecedented numbers. A U.S. News \& World survey had federal judges rate the high court. (They gave it low marks.) How U.S. Judges Feel About the Supreme Court, U.S. NEWS \& WORLD REP., Oct. 24, 1958, at 34, 36-37 (reporting a U.S. News \& World Report poll of federal judges regarding their opinions of the U.S. Supreme Court); see also U.S. Judge in South Assails High Court, N.Y. TIMES, July 26, 1957, at 6 (quoting Judge George Bell Timmerman who labeled the Court "a hierarchy of despotic judges that is bent on destroying the finest system of government ever designed"). Earl Warren, Hugo Black, Arthur Goldberg, and William O. Douglas also took to the hustings to defend the Supreme bench, while Henry Friendly and (of course) Learned Hand challenged them. See William O. Douglas, On Misconception of the Judicial Function and the Responsibility of the Bar, 59 COLUM. L. REV. 227, 231-32 (1959); Arthur J. Goldberg, The Court Sits-in the Center of the Storm, N.Y. TIMES, Nov. 8, 1964, § 6 (Magazine), at 30; Earl Warren, The Law and the Future, FORTUNE, Nov. 1955, at 107 ("Our judges are not monks or scientists, but participants in the living stream of our national life."). One commentator finally had to "speculate whether there is connection between recent assertions of enlarged judicial power and the increasing frequency of public addresses by the Justices not of a ceremonial nature but involving issues in litigation, ... defending the Court and criticizing its critics." Emest J. Brown, Quis Custodiet Ipsos Custodes?-the School Prayer Cases, 1963 SuP. CT. REV. 1, 3 n.7.

194. They were not always consistent in the message. For Hart, academic criticism of the Court was new and undeveloped. See supra note 191 and accompanying text. For Bickel, the academic debate was "timeless." See Alexander M. Bickel, Mr. Justice Black: The Unobvious Meaning of Plain Words, NEW REPUBLIC, Mar. 14, 1960, at 13 (referring to the critical professional examination of the Court's function as "muted, constant and timeless").

195. Id. at 13. Bickel, however, recognized that it is more than a matter of academic debate.

196. Is the Supreme Court Reaching for Too Much Power?, U.S. NEWS \& WORLD REP., Oct. 7,1963 , at 64 .

197. See Alexander M. Bickel, Crime, the Courts, and the Old Nixon, NEw REPUBLIC, June 15, 1968, at 8 [hereinafter Bickel, Crime, Courts]; Alexander M. Bickel, Is the Warren Court Too "Political"?, N.Y. TIMES, Sept. 25, 1966, §6 (Magazine), at 30 [hereinafter Bickel, Warren Court] (discussing the criticism of the Warren Court); Charles L. Black, Jr., Mr. Justice Black, The Supreme Court and the Bill of Rights, HARPER's, Feb. 1961, at 63; Fred Rodell, Crux of the 
observed, "He has been followed by a clutch of law and political science professors, the result being a number of papers which constitute a debate which has now reached such a degree of prominence, if not permanence, that it is itself the object of commentary."198

Once they became part of the public debate, these academic critics actually served - undoubtedly against their will and best intentions-to give aid to the popular critics of the Court. Newsweek easily linked in opposition to the Court "critics, who range from the know-nothings of the extreme right to the savants of the law schools." ${ }^{\text {999 }}$ Nor should this be surprising; a lengthy report in Time on July 1, 1957, was largely positive about the Communist decisions, but the tenor of the entire article turned on reporting the doubts of the single dissenting voice: Professor Gerald Gunther. ${ }^{200}$ The most notable example of perhaps unintended crossover was when Learned Hand was caught as a pawn in the contentious debate over the Jenner-Butler Bill. Throughout the course of the hearings his recently delivered Holmes Lectures had been cited repeatedly by those who favored Court-curbing. ${ }^{201}$ When he again became the focus of attention during the floor debates, he was spurred to action to make clear that his position was being misused. ${ }^{202}$ Charles Black early on was compelled to observe that the "greatest threat" to judicial review came not from threats of constitutional amendment or congressional legislation, but "a quieter one, working within the legal profession, in the pages of the law reviews, in those self-doubts which the judges, like all other honest men in power, must recurrently feel. ${ }^{203} \mathrm{He}$ found it surprising that "a number of scholars of the law, friends, in the main, neither of the suppression of political eccentricity nor of racism, have

Court Hullabaloo, N.Y. TIMES, June 19, 1960, $\$ 6$ (Magazine), at 13 (discussing the proper role of the Court and observing that "much of the nation and the press views the court with suspicion or mistrust"); Fred Rodell, The Warren Court Stands Its Ground, N.Y. TIMES, Sept. 27, 1964, §6 (Magazine), at 23 [hereinafter Rodell, Warren Court Stands Its Ground] (discussing the Warren Court's exercise of political-legal power).

198. Miller, supra note 185 , at 188.

199. The Warren Court: Fateful Decade, NEwSwEEK, May 11, 1964, at 24.

200. The Supreme Court: The Temple Builder, supra note 132, at 14. In response to the Communist decisions, Professor Gunther stated, "There comes a point where a democratic government won't allow an unelected body to substitute its value judgments for those of an elected body. This is a trend that can be dangerous." Id.

201. According to Professor Gunther:

Senator Roman Hruska of Nebraska was the first to call the committee's attention to Hand's remarks, presenting an editorial which praised "the distinguished Judge" for saying that the High Court does legislate, and adding that "that conclusion is quite like the premise on which Senator Jenner [had] based his bill to curb the Court." In ensuing weeks, these references to Hand's lectures and renown became prominent themes.

GUNTHER, supra note 186, at 660; see also Jenner-Butler Hearings, supra note 178, at 76, 219 , 431 (reporting testimony specifically referring to Hand's lectures).

202. 104 CONG. REC. 18,673 (1958) (quoting a letter from Hand).

203. BLACK, supra note 1 , at 191. 
in effect joined hands" with the Supreme Court's more ideological critics. ${ }^{204}$

\section{Bickel, the "Counter-Majoritarian Difficulty," and the Second Warren Court}

One of the Court's sometime critics was the young Alex Bickel. In 1962 he published The Least Dangerous Branch. Bickel's fascinationindeed the central metaphor for the book-was the "Lincolnian tension" between "principle" and "expediency." In Bickel's view, when the Court acted, its special role required that it do so on the basis of principle. Yet, because the success of judicial review depended ultimately on popular acceptance, sometimes expediency necessarily must trump principled decisionmaking. In The Least Dangerous Branch, Bickel suggested the resolution of this tension rested in careful use of the "passive virtues," which essentially meant using doctrinal tools to duck problematic questions until society has had time to grapple with them. ${ }^{205}$

Yet, it was the framing device he employed for his argument that caught the attention of the ages. In the opening chapter of The Least Dangerous Branch, Bickel employed the phrase "the counter-majoritarian difficulty," by which he meant the problem of reconciling judicial review with the workings of democratic government. ${ }^{206}$ According to Bickel, when the Supreme Court invalidates the work of an actor who is subject to the electoral process, the Court "exercises control, not in behalf of the prevailing majority, but against it." 207 Nothing in the "complexities" that Bickel saw in the American system of government could "alter the essential reality that judicial review is a deviant institution in the American

204. Id. at 156 .

205. See BICKEL, supra note 16, at 115 ("One of the chief faculties of the judiciary, which is lacking in the legislature and which fits the courts for the function of evolving and applying constitutional principles, is that the judgment of courts can come later, after the hopes and prophecies expressed in legislation have been tested in the actual workings of our society."); Alexander M. Bickel, The Supreme Court, 1960 Term-Foreword: The Passive Virtues, 75 HARV. L. REV. 40, 51 (1961) (stating that the Court employs devices to "give[] electoral institutions their head and... stays out of politics"); see also Brown, supra note 193, at 16 (arguing that standing doctrine should be narrowed to avoid the expansion of judicial exposure to political questions); Deutsch, supra note 185, at 207-08 ("Both Bickel and Wechsler, for the same reason-the desire to render exercise of the Court's power compatible with the fact of its political irresponsibility-attempt to formulate courses of action that will take the Court out of politics."); Bickel, Warren Court, supra note 197, at 130 (suggesting that the Court should have waited until the American Law Institute's proposal on police procedures had come to fruition before deciding Miranda in order to be in a position to review rules formulated by others).

206. BICKEL, supra note 16, at 16 ("The root difficulty is that judicial review is a countermajoritarian force in our system.").

207. Id. at 17. 
democracy." 208 "It is this reason the charge can be made that judicial review is undemocratic."209

Bickel's description of the countermajoritarian problem gained prominence in the decade following publication of The Least Dangerous Branch $^{210}$ and ultimately came to grip the attention of a generation of constitutional theorists. His influence was evident as academics responded to the Warren Court's most active phase, during the 1960 s.

\section{The Busy Sixties}

As Kermit Hall has said, "There were, in fact, two Warren Courts,"211 the second beginning in 1962. Warren Court activism increased in 1962, when changes in the Court's personnel shifted the balance in an important way. ${ }^{212}$ Byron White was selected by President Kennedy to replace the conservative Whittaker. Felix Frankfurter, the legendary voice for judicial restraint, had a stroke and resigned, only to be replaced by Arthur Goldberg (and later Abe Fortas when Goldberg left his seat on the Court for the Ambassadorship at the United Nations). ${ }^{213}$

As Warren Court activism increased, it quickly became clear that public perceptions of the Court and academic concern about the role of the Court

208. Id. at 1; see also Kenneth Ward, Alexander Bickel's Theory of Judicial Review Reconsidered, 28 ARIZ. ST. L.J. 893, 897 (1996) ("[Bickel] defends judicial review, even though he considers it a deviant institution in American democracy.").

209. BICKEL, supra note 16, at 16.

210. See Howard E. DeAn, Judicial Review AND Democracy 5 (1966) ("The Supreme Court, its critics claim, is a veritable aristocracy of the robe, functioning as a super-legislature, yet neither chosen by the people nor politically responsible to them. Since in a democracy it is the responsibility of the people to correct errors of the government, that vital function should never be surrendered into the hands of a body of judicial 'Platonic Guardians."'); SHAPIRO, supra note 65, at 13 ("[I]t is true that Supreme Court justices are not directly responsible to the people in the sense that elected officials are, and it is equally obvious that government by nine specialists, appointed for life and at least theoretically insulated from the political process, smacks of something other than democracy."); Henkin, supra note 185, at 659 ("The critic may . . demand that the Court keep in mind that democracy implies respect for majorities ... [and] ask whether the Court is the one to lead the reluctant rest to that promised democracy."); Kurland, supra note 156 , at 465-66 ("JJ]udicial activism should be rejected because it replaces a representative legislature with a group which is neither representative nor responsible to anyone but itself. Judicial activism is undemocratic."); Clifton McCleskey, Judicial Review in a Democracy: A Dissenting Opinion, 3 HoUS. L. REV. 354, 357 (1966) ("It would seem self-evident that the existence of judicial power to override the policy decisions of popularly elected officials cannot be squared with [democracy]."); Robert H. Bork, The Supreme Court Needs a New Philosophy, FORTUNE, Dec. 1968, at 140 . (" $[\mathrm{M}] \mathrm{en}$ are likely to prefer legislatures more representative of contending interest groups, more mindful of social complexities, and, most important, more subject to control-legislatures, that is, whose members can be voted in and out of office.").

211. Kermit L. Hall, The Warren Court: Yesterday, Taday, and Tomorrow, 28 IND. L. REV. 309,314 (1995).

212. MORTON J. hoRwitz, The TRansformation of American LaW 1870-1960: THE CRISIS OF LEGAL ORTHODOXY 252 (1992); Tushnet, supra note 184, at 7.

213. Tushnet, supra note 184 , at 7. 
were quite distinct. The Court's next three initiatives were school prayer, reapportionment, and the rights of criminal defendants. Although the Court continued to come under attack, or receive praise, based on what the public thought of its reform efforts, the academy saw each project quite differently.

\section{a. School Prayer: 1962-1963}

In 1962, and again in 1963, the Supreme Court rendered extremely unpopular decisions regarding prayer in schools. ${ }^{214}$ The 1962 decision in Engel v. Vitale banned the use of New York's "Regent's Prayer" in schools, ${ }^{215}$ while the 1963 decision in School District $v$. Schempp banned the reading in classrooms of the "Lord's Prayer" or bible verses. ${ }^{216}$ Both polls and news coverage make clear that a majority of the population opposed the decisions. ${ }^{217}$ Engel, particularly, created quite a stir, ${ }^{218}$ and numerous proposals were introduced in Congress to amend the Constitution

214. Id. at 20 (calling the decisions "wildly unpopular").

215. 370 U.S. 421 (1962).

216. 374 U.S. 203 (1963).

217. See 3 GALLUP, supra note 132, at 2021-22 (reporting the results of a 1963 poll asking, "The United States Supreme Court has ruled that no state or local government may require the reading of the Lord's Prayer or Bible verses in public schools. What are your views on this?" in which $24 \%$ of respondents approved of the ruling, $70 \%$ disapproved, and $6 \%$ had no opinion); LOUIS HARRIS \& ASSOCS., HARRIS 1966 ELECTION SURVEY, NO. 1643 (Sept. 1966), at http://www.irss.unc.edw/data_archive/pollsearch.html (asking, "Another decision of the U.S. Supreme Court was to rule that children could not be required to recite a prayer in school. Do you personally think that decision of the U.S. Supreme Court was right or wrong?" and finding that $26.9 \%$ of those polled felt this decision was right, $65.5 \%$ believed it to be wrong, and $7.6 \%$ were not sure); ROPER CTR. AT UNIV. OF CONN., PUBliC OPINION ONLINE (Nov. 1966), at http://web.lexis-nexis.com/universe (reporting the results of a study performed by Louis Harris $\&$ Associates and reported in the Philadelphia Inquirer in which $70 \%$ of respondents felt that banning school prayer from public schools was wrong); Walter F. Murphy \& Joseph Tanenhaus, Public Opinion and The Supreme Court: The Goldwater Campaign, 32 PUB. OPINION Q. 31, 3436 (1968) (reporting a University of Michigan survey of 1450 people of voting age, where the decisions banning school prayer were the second most frequently mentioned subject, with only the civil rights of Negroes ranking above it, and where approximately $30 \%$, or 280 , of those polled referred to the school prayer decisions, and 253 of those stated that they disliked the Court's decision in that area); see also THOMAS R. MARSHALL, PUBlic OPINION AND THE SUPREME COURT 136 (1989) ("In one small Midwestern town,... community leaders were asked, first, whether they agreed with the Supreme Court's school prayer decisions and second, whether they felt obligated to accept that decision. Of those who disagreed with the school prayer ruling, only a third (36\%) also reported that they had a duty to accept the decisions...."); God Save This Honorable Court, NAT'L REV., July 17, 1962, at 11 ("'Engel] expresses the conviction of, at most, ten per cent of the citizenry; some, as on most public matters, are doubtless indifferent; but there is without question an overwhelming majority that disagrees.").

218. See Michael Kammen, The Machine That Would Go of ItSelf 316 (1986) (citing a 1963 poll that showed $70 \%$ of Americans opposed school prayer rulings). 
to permit school prayer. ${ }^{219}$ The furor over Engel was relatively shortlived, ${ }^{220}$ however, and Schempp produced a less severe reaction. ${ }^{221}$

Nearly all of the criticism of these decisions was on the merits (i.e., that the Court had interpreted the Constitution incorrectly). Commentators assailed the decisions as removing religion from society and as an incorrect interpretation of precedent, tradition, and history. ${ }^{222}$ But dissatisfaction with prior Court actions also fed into criticism of the school prayer decisions. ${ }^{223}$

219. See, e.g., Anthony Lewis, Both Houses Get Bills To Lift Ban on School Prayer, N.Y. TIMES, June 27, 1962, at 1 (discussing proposed bills that would overrule Engel and permit the reading of prayers and Bible verses in public schools). The Gallup Organization conducted a poll in 1964 gauging public opinion with respect to a constitutional amendment legalizing prayers in public schools. The results reflected public support for the amendment, with $77 \%$ of respondents indicating that they would favor the amendment, $19 \%$ indicating that they would oppose it, and $5 \%$ indicating that they did not know. ROPER CTR. AT UNIV. OF CONN., PUBLIC OPINION ONLINE (Sept. 1964), at http://web.lexis-nexis.com/universe (reporting the results of a study performed by the Gallup Organization for Potomac Associates in which the following question was asked: "The U.S. Supreme Court has held that prayers in public schools are unconstitutional because they violate the doctrine of separation of church and state. Would you favor or oppose a constitutional amendment to legalize prayers in public schools?").

220. See Raymond Moley, God, Man and Liberty, NewsweEK, July 23, 1962, at 76 (noting that within a month of the Engel decision, the protests had "died down").

221. See Anthony Lewis, New Judges and Doctrines Alter Character of Supreme Court, N.Y. TIMES, June 23, 1963, at 64 ("[T] he reaction [to later school prayer cases, including Schempp] was certainly much more accepting of the court's doctrine that government must be 'neutral' toward religion."). It is difficult to say with precision what accounted for the relatively muted criticism in response to the school prayer decisions. Pluralist notions of democracy seem to have held sway here much more than during the Communist controversy. As indicated above, prominent pluralist theories mirrored increased popular sensitivity to minority rights, that sensitivity itself resulting both from United States opposition to totalitarian regimes elsewhere and from the Negro rights decisions of the Supreme Court. See Ross, supra note 50, at 606 ("During the 1960s, the Court's decisions on religion in the schools received critical support from major religious denominations, and reflected the increased level of religious pluralism in America."); see also sources cited supra note 62. One lengthy editorial in Commonweal questioned explicitly whether the school prayer decisions furthered or interfered with the pluralist conception of American life. The Court on Prayer, CommonwEAL, July 13, 1962, at 387. These strains are evident in contrasting editorials in the New York Times and the Wall Street Journal about Engel v. Vitale. Compare Editorial, N.Y. TIMES, June 27, 1962, at 34 ("[T]here are persons who want to pray in their own way, or not at all. Doubtless those who oppose school prayers are a minority. But the Constitution was designed precisely to protect minorities; and the First Amendment bars the majority at any time from ordaining 'an establishment of religion."'), with In the Name of Freedom, WALL ST. J., June 27, 1962, at 14 ("[A]ny actual attempt to establish a specific state religion is a danger that ought to be easily recognizable. But it is something entirely different to suppose that, short of unimaginable police tactics, teaching about religion can be divorced from the American education with which it is inextricably bound up as a central fact of our heritage. Those who persist in such attempts had best take care lest, in the name of religious freedom, they do real damage to free institutions.").

222. For criticism on the merits, see 108 CONG. REC. 11,720 (1962) (statement of Rep. Jensen) ("This is a deliberate annihilation of a historical and sacred custom."); 108 CONG. REC. 11,719 (1962) (statement of Rep. Puff) ("[Engel] represent[s] a complete departure from established practice and precedent in American jurisprudence."); and God Save This Honorable Court, supra note 217 at 10 (" $[\mathrm{I}] \mathrm{f}$ this is what the First Amendment means now, then it contradicts what it meant on June 24 and for 173 years before then.").

223. See JAMEs E. Clayton, The MAKING OF JUSTICE 16-17 (1964) (suggesting that resentment of the reapportionment decisions fueled the criticism in the school prayer decisions). 
Members of Congress in particular used the occasion to reopen older sores. "Southern members of Congress were among the most prominent critics," the New York Times reported. Representative L. Mendel Rivers of South Carolina accused the Court of "legislating-they never adjudicate-with one eye on the Kremlin and the other on the National Association for the Advancement of Colored People."224 Representative George Andrews of Alabama said, "They put the Negroes in the schools and now they've driven God out.",225

Quite unlike the public, however, elite academics seemed content with the school prayer decisions on the merits. These were a genuinely countermajoritarian set of decisions, or so it seemed, but academics who might have been expected to level this complaint agreed with the Court on the merits, and thus grumbled about other things. Although there were variants on the message, the general theme was the same. Bickel here might be our guide:

Complete secularization of the public schools is for many of uswho may be a minority ... - an ultimate ideal. But is this the time to ventilate the issue of religion in ... absolute terms? ... Principle is one thing, no matter how worthy and valid, but the wise and effective government of a free society is sometimes quite
another. 226

Academics thought the Court had the merits right, but should have ducked what was, in their view, not so much of a problem. ${ }^{227}$ Scholars also seemed

Some observed that politicians who could not attack the Court as directly on the reapportionment issue undoubtedly used school prayer as a proxy. The prior debate on the Communist decisions also might have had some effect. Note that the proposals this time around were to amend the Constitution, not to curb the Court. Indeed, the National Review, perhaps for this reason and perhaps because it recognized an amendment would not succeed, suggested simply that Congress issue a resolution against the Court decisions. L. Brent Bozell, Saving Our Children from God, NAT'L REV., July 16, 1963, at 19.

224. Lewis, supra note 219 , at 20.

225. Lewis, supra note 219, at 20 ("[Alabama Representative Thomas G.] Abernathy said the decision would please no one but a 'few atheists' and world Communism."); Anthony Lewis, Supreme Court Outlaws Official School Prayers in Regent's Case Decision, N.Y. TIMES, June 26, 1962; see also CLAYTON, supra note 223, at 17 ("I know of nothing in my lifetime that could give more aid and comfort to Moscow than this bold, malicious, atheistic and sacrilegious twist by this unpredictable group of uncontrolled despots.... The Court has now officially stated its disbelief in God Almighty." (quoting South Carolina Representative Mendel Rivers)); id. ("I should like to ask whether we would be far wrong in saying that in this decision the Supreme Court has held that God is unconstitutional and for that reason the public schools must be segregated against him." (quoting North Carolina Senator Sam J. Ervin)).

\section{AlEXANDER BICKEL, POLITICS AND THE WARREN COURT 208 (1965).}

227. See MCCLOSKEY, supra note 63, at 315-16 (arguing that although Engel and its progeny were "to some degree objectionable, ... a strong case could be made for judicial avoidance of the whole issue of state aid to religion, at least for the time being"); Philip Kurland, The Regents" Prayer Case: "Full of Sound and Fury, Signifying ...," 1962 SUP. CT. REV. 1, 32-33 (noting that while "Vitale may come to be recognized as one of the bulwarks of American freedom[,] ... if 
annoyed by the Court's inartful dodging of the standing issue, which these academics saw as the perfect way for the Court to avoid hearing these cases at all. ${ }^{228}$

\section{b. Reapportionment: 1962-1969}

In the reapportionment cases, the Supreme Court offered its own definition of democracy, one that was met with broad approval by the American public. ${ }^{229}$ In 1962, in Baker v. Carr, ${ }^{230}$ a case involving the apportionment of the Tennessee legislature, the Supreme Court departed from its decision in Colegrove $v$. Green, ${ }^{231}$ which had held that reapportionment controversies were political questions. Baker was followed by the 1964 decision in Wesberry v. Sanders, ordering the redrawing of malapportioned federal congressional districts consistent with the one person, one vote principle. ${ }^{232}$ Later that Term, the Court held that the one person, one vote principle must be applied to all state legislative houses in Reynolds $v$. Sims, a decision it followed steadfastly. ${ }^{233}$

Although politicians were understandably troubled ${ }^{234}$-after all, they might be redistricted out of a job-the general public was tremendously

discretion proves again to be the better part of valor, the Court will manage to avoid decision in the Bible-reading cases").

228. See Kurland, supra note 227, at 19, 22 ("The silence of the Court in Vitale on the question of the right of petitioners to raise the question of separation is certainly somewhat enigmatic. ... To sustain jurisdiction where no [direct, individual, economic] interest is shown is to forswear a major function of judicial opinions ...."); Arthur E. Sutherland, Jr., Establishment According to Engel, 76 HARV. L. REV. 25, 45 (1962) (noting the Engel Court's "rather curious sparseness of mention of the petitioning plaintiffs or of their children, does not tell how far it intends a change in traditional standing. ... [T]

229. See Robert C. Post, William J. Brennan and the Warren Court, in THE WARREN COURT IN HistoriCAL AND POLITICAL PERSPECTIVE, supra note 184, at 123, 125-26 (describing how the reapportionment decisions represented the Warren Court's vision of democracy).

230. 369 U.S. 186 (1962). The decision in Baker obviously was applicable to numerous other state legislatures, which is the reason the decision caused a stir. The Court had eschewed reliance on a possible narrower ground of decision: Although the Tennessee Constitution required decennial reapportionment, the legislature had not been reapportioned since 1901. Id. at 189-91.

231. 328 U.S. 549 (1946).

232. 376 U.S. 1 (1964).

233. 377 U.S. 533 (1964); see also Lucas v. 44th Gen. Assembly of Colo., 377 U.S. 713, 734-35 (1964) (holding that a majority in a state cannot deprive any minority of equal voting rights); WMCA, Inc. v. Lomenzo, 377 U.S. 633 (1964) (relying on the population principle in Reynolds to invalidate the state of New York's reapportionment scheme).

234. In a fit of pique, the Senate voted to reduce for Supreme Court Justices the pay raise it awarded to other federal judges.

In approving last week a badly needed salary increase for Federal officials, the Senate added a mischievous amendment aimed at the Supreme Court. It would hold the raise for the nine justices to only $\$ 2,500$, instead of the $\$ 7,500$ provided for all other top judges, members of Congress and executive officers .... It was doubtless the Court's decision last month in the Colorado legislative apportionment case, holding that a majority in a state cannot deprive any minority of equal voting rights, that irritated amendment author Senator Allott. Other Senators were moved by displeasure at the 
supportive of these decisions. ${ }^{235}$ Newsweek anticipated the decisions by roughly two years and contrasted them with Brown, in which enforcement "had to be carried out in a region where the overwhelming majority of the people were adamantly opposed to the decision." Newsweek's conclusion was prescient: "With a reapportionment decision, the overwhelming majority of Americans would be in favor of what the Supreme Court had done. ${ }^{, 236}$ And so they seemed to be. ${ }^{237}$

verdicts in other controversial issues recently decided by the Court, such as the issues of racial segregation or prayer in the schools.

Editorial, Low Blow at the Supreme Court, N.Y. TIMES, July 6, 1964, at 28.

235. Ross, supra note 50, at 606 ("Opinion polls indicated that the Court's decision in Reynolds, the most sweeping of its reapportionment decisions, received far more support than disapproval."). For results of public opinion polls taken with respect to congressional reapportionment, see LOUIS HARRIS \& ASSOCS., supra note 217 (sampling voters who, in response to the question, "Another decision of the U.S. Supreme Court was to rule all Congressional Districts had to have an equal number of people in them so each person's vote would count equally. Do you personally think that decision of the Supreme Court was right or wrong?" indicated general approval for the ruling- $57.0 \%$ felt the decision was right, $18.6 \%$ felt it was wrong, and $24.4 \%$ were not sure). See also ROPER CTR. AT UNIV. OF CONN., supra note 217 (reporting the results of a study performed by Louis Harris and Associates and cited in the Philadelphia Inquirer in which $76 \%$ of respondents felt the decision was right and $24 \%$ felt it was wrong). For results of public opinion polls taken with respect to the Reynolds decision, see 3 GALLUP, supra note 217, at 1897 (asking in a poll taken between July 23, 1964, and July 28, 1964: "As you know, the United States Supreme Court has ruled that the number of representatives of both the lower house and the Senate in all state legislatures must be in proportion to population. In most states, this means reducing the number of legislators from the rural areas and increasing the number from urban areas. Do you approve or disapprove of this ruling?" and finding that $47 \%$ approved, $30 \%$ disapproved, and $23 \%$ had no opinion). There were moves made in state and federal legislatures to delay or overturn the decision. Congress engaged in a variety of efforts to avoid the decisions, among them proposing congressionally mandated delay, stripping the federal courts of jurisdiction over reapportionment matters, and proposing a constitutional amendment. See Andrew Hacker, One Man, One Vote-Yes or No?, N.Y. TIMES, Nov. 8, 1964, \$ 6 (Magazine), at 31 ("Leaders in both [Houses] have promised to introduce resolutions for amending the Constitution that would permit one House in each state to be based on nonpopulation factors."); How Congress Is Trying To Cut the Supreme Court's Power, U.S. NEWS \& WORLD REP., Aug. 31, 1964, at 8 (reporting on a bill, which passed the House, to strip federal courts of their power to rule on apportionment of state legislatures and on a Senate proposal to postpone enforcement of the reapportionment decisions). An effort was made in state legislatures to pursue a constitutional amendment that would have, among other things, created a Court of the Union comprised of the fifty state supreme court chief justices, with power to overturn decisions of the United States Supreme Court. See generally Kenneth Crawford, Reaction's Refuge, NEWSWEEK, June 3, 1963, at 31 (commenting on the states' reactionary efforts to nullify the recent reapportionment decisions); Anthony Lewis, Ten States Ask Amendment To Gain Districting Rights, N.Y. TTMES, Apr. 14, 1963, at 1 (noting that the "real impetus" of the Court of the Union proposal was the Court's reapportionment decision); Silent Amendments, NEWSWEEK, May 20,1963, at 35, 36 (noting the states' efforts to respond to the Court's reapportionment decision, including an amendment to the process by which states could amend the Constitution, a Court of the Union whereby state courts could overrule Supreme Court decisions, and a prohibition on allowing federal courts to rule on state reapportionment issues).

236. The "Second Class" City Dwellers, NEWSWEEK, Oct. 23, 1961, at 26.

237. Even those opposed to the decisions regularly conceded their popularity, as did Bickel in commenting unfavorably on Baker v. Carr, which "has evoked a speedy, ample, and largely favorable response." Alexander M. Bickel, Reapportionment and Liberal Myths, 35 COMMENTARY 483 (1963); see also Kurland, supra note 49, at 167 (suggesting that there are 
It was the "democratic" nature of the decisions that so seemed to please Americans. As President Kennedy said, undoubtedly speaking the mind of millions, "Quite obviously the right to fair representation, that each vote count equally is, it seems to me, basic to the successful operation of a democracy." 238 Or, as the Saturday Evening Post opined, "What the court has really done is to open a vista for a more complete democratic process through fairer representation." ${ }^{, 239}$ Commentators observed that modern-day Americans appeared to have opted for a democracy in which popular majorities held greater sway than the Framers intended, at least insofar as incumbent officeholders were concerned. ${ }^{240}$

In the face of such "democratic" approval, the rare expression of countermajoritarian criticism looked silly. Comments like that of Senator Everett Dirksen, writing in the Saturday Evening Post, that the "will of six men on the Supreme Court" was contrary to the will of the people, were rare, probably because they were not true. ${ }^{241}$ The judiciary apparently was the only place to go when malapportionment had locked out the will of the people, who could not get politicians, anxious to retain their employment, to solve the problem themselves. ${ }^{242}$

"many" who are not convinced that the Supreme Court exceeded its role in the reapportionment decisions); J. Skelly Wright, The Role of the Court: Conscience of a Sovereign People, REPORTER, Sept. 26, 1963, at 27 ('In state after state, citizens' groups have stepped forward, swiftly and effectively, to demand enforcement of the Constitutional principles of equality of which the Supreme Court had reminded them.").

238. Bickel, supra note 237, at 487.

239. The Court Steps in, SATURDAY EVENING POST, May 5, 1962, at 92; see also Bickel, supra note 237, at 488 ("[T] he problem of democracy becomes one of access to, participation in, influence on the process of decision, and only ultimately and in necessarily attenuated fashion one of ensuring at election time the legislature's fidelity to the popular will."); Editorial, $A$ Gain for Majority Rule, N.Y. TIMES, Mar. 27, 1962, at 36 ("[I]t is certainly the concern of the entire United States that state governments should be democratic."). But see Raymond Moley, Reapportionment Mess, NEWSWEEK, June 21, 1965, at 104 ("Apparently, the only kind of democracy that is to be tolerated in the present dispensation is Supreme Court democracy.").

240. As Robert McCloskey said, "[I]nstitutions sometimes lag behind opinion, and it may be that most Americans have come to think of some version of the majority principle as at least the presumptive democratic standard." McCloskey, supra note 185, at 59. Commentators also questioned whether malapportionment had anything to do with pluralist theory. See Carl A. Auerbach, The Reapportionment Cases, One Person, One Vote-One Vote, One Value, 1964 SuP. CT. REV. 1, 30-31 (noting that an examination of criticism of the reapportionment decisions occasionally reveals a misunderstanding of the principles of pluralism and group representation).

241. Everett McKinley Dirksen, The Supreme Court Is Defying the People, SATURDAY EVENING Post, Sept. 12, 1964, at 10.

242. See The Court Steps in, supra note 239 ("Apparently the judges concluded that the Supreme Court should function occasionally as a tribunal of last resort for the American system after all the other political processes fail."); Louis L. Jaffe, The Court Debated-Another View, N.Y. TIMES, June 30, 1960, $\S 6$ (Magazine), at 36,56 ("If leadership is stymied in the Legislature, it is appropriate that it work in some measure through the courts."); Alpheus Thomas Mason, The Supreme Court Under Fire Again, REPORTER, Sept. 24, 1964, at 45, 48 ("The Court's emergence ... as guardian and defender of civil liberties, its assertion of responsibility for basic freedoms, has resulted from a critical breakdown of our democratic institutions."). 
Nonetheless, legal academics were discontent with the decisions, ${ }^{243}$ and leveled their criticism in countermajoritarian terms, odd though this was. In fairness, some of the academic commentary was premised on thoughtful consideration of the impact of the Court's one person, one vote rule on pluralist politics. ${ }^{244}$ Yet, even the approving academics mouthed what was becoming a common refrain, urging the Court not to move too quickly. ${ }^{245}$ Kurland, for example, took the position that malapportionment was not a pressing problem, a position belied by the widespread public approval that he and others noted. ${ }^{246}$

243. See Bickel, supra note 237 , at 488 ("[T]he heart of the matter is that democratic government rests on consent. ... [I]t is the sense shared by all that their interests were spoken for in the decision-making process, no matter. how the result turned out. Government by consent requires that no segment of society should feel alienated from the institutions that govem."); Phil C. Neal, Baker v. Carr: Politics in Search of Low, 1962 SUP. CT. Rev. 252, 276-77 ("[T] principle of districting within each [governmental] unit reflects our conviction that the general interest, and the innumerable separate interests of which it is composed, will be better expressed in a medley of voices from minor fractions of the population than by any monolithic majority.").

244. See, e.g., Neal, supra note 243.

245. See, e.g., MCCLOSKEY, supra note 63, at 288 (speaking approvingly of the decisions, but advising the Court regarding the reapportionment decisions that "before they proceed to the next lesson, they would be well advised to speculate about the precise nature of this consensus they seem to have aroused," and noting that "if the judiciary should go beyond the premise of popular consent and attempt to prescribe 'from its own bosom' what the populace may consent to, the climate might alter drastically"). Conservative commentators tended to agree. See, e.g., Holman Harvey \& Kenneth O. Gilmore, Reapportionment: Shall the Court or the People Decide?, READER'S DIG., Mar. 1965, at 111, 114-15 ("Some groups of voters can be wiped out, under a 'winner-take-all' numerical system. [Baker] will tend to weaken the complex American system for diffusing power and protecting minorities."' (citations omitted)). Typical was Raymond Moley who, taking a traditional conservative tack, chastised readers for thinking "that this is a democracy rather than a republic. Indeed, every sort of prudent device was incorporated in the Constitution to prevent such a degeneration." Raymond Moley, A Great Dissent, NEWSWEEK, Apr. 16, 1962, at 116. "True representation," he insisted, in an argument advanced by many reapportionment opponents, "involves interests as well as majorities." Id.; see also Raymond Moley, Who Represents What?, NEWSWEEK, Mar. 9, 1964, at 88 ("Representation in our system of govemment is not ... that 'one vote should be equal to another.' Areas and the common interests therein deserve representation in certain cases.... The use of the word 'democratic,' meaning one-man-one-vote merely confuses the issue .....').

246. KURLAND, supra note 175 , at 95 (arguing that "the reapportionment problems represented nothing more than a case of bad acne, frequently embarrassing and temporarily disfiguring but not of vital importance" while at the same time noting that people are "accepting of the one man-one vote principle"). Bickel was also disparaging of the reapportionment decisions. BICKFL, supra note 226, at 190 (challenging the assumption that malapportionment is a problem, and even when accepting for argument's sake that reapportionment is necessary, declaring that "the remedy lies with the majoritarian executive, whom we can influence"); Alexander M. Bickel, Reapportionment and the Courts, New RePUBLIC, June 27, 1964, at 7 (concluding that although " $t \mathrm{t}] \mathrm{he}$ court's rulings on apportionment have been popular, ... it will not prove satisfactory now to leave final decisions of such pragmatic questions to lifetime federal appointees responsible only to other lifetime appointees in Washington"). 


\section{c. The Rights of Criminal Suspects}

The Warren Court may have been undone in the popular mind by its final reform effort: expanding the protections of criminal suspects. The Court had survived widespread defiance of Brown, attempts to strip its jurisdiction after the Communist decisions, and calls for constitutional amendment during the school prayer controversy, but the criminal procedure decisions would so turn the public against it that a presidential election would turn partly on this issue, and bring the era of the Warren Court to a close. In a series of decisions, the Warren Court "nationalized" the rules of criminal procedure, and extended the constitutional protections accorded suspects in criminal investigations and prosecutions. Notable among these decisions were Mapp $v$. Ohio, ${ }^{247}$ applying the Fourth Amendment exclusionary rule to the states, Gideon v. Wainwright, ${ }^{248}$ requiring that the states provide criminal defendants with counsel, and Miranda $v$. Arizona, ${ }^{249}$ requiring the reading of now-famous "Miranda" rights before a confession elicited by police interrogation could be introduced into evidence.

Crime rates seemed to work against the Court ultimately. When they were low, criticism was muted, but when they rose throughout the later 1960s, the Court was attacked fiercely. Although there were some complaints, ${ }^{250}$ the public generally was approving of early efforts to extend the protections afforded criminal suspects, and some decisions like Gideon were warmly applauded. ${ }^{251}$ Public approval might have rested on the link that was forged early on between racial issues and criminal justice

247. 367 U.S. $643(1961)$.

248. 372 U.S. $335(1963)$.

249. 384 U.S. 436 (1966). Two of the most vilified decisions are, ironically, the least significant today: Mallory v. United States, 354 U.S. 449 (1957), and Escobedo v. Illinois, 378 U.S. 478 (1964).

250. See High Court Bars Evidence States Seize Illegally, N.Y. TIMES, June 20, 1961, at 1 ("Some observers quickly described it as the most significant limitation ever imposed on state criminal procedure by the Supreme Court in a single decision."); Rewriting the Rules, supra note 64, at 22 ("This decision deprives us of the cooperation of the person who knows the most about the crime-the one who committed it-and puts the handcuffs on the police instead of on the criminal."); State Prosecutors Will Fight U.S. Curb on Illegal Evidence, N.Y. TTMES, July 2, 1961, at 24 (noting efforts by the District Attorney's Association of the State of New York, which argued that "the new Court ruling would "render law enforcement in the state less effective").

251. Ross, supra note 50, at 606 ("[T] particularly its decision on right to counsel in Gideon $v$. Wainwright, were broadly hailed for their fundamental faimess, an attitude that in part reflected changing public attitudes toward poverty."); see also Counsel for Poor Acclaimed by Bar, N.Y. TIMES, Mar. 22, 1963, at 5 (reporting that the ABA "strong[ly] support[s]" Gideon, touting it as a "great advance[] in the administration of criminal justice in our country"); Anthony Lewis, The Criminal Law Cases, N.Y. TiMEs, Mar. 21, 1963, at 6 (describing the reaction to the Gideon decision as one of "readiest public acceptance"); Anthony Lewis, Supreme Court Changes Again, N.Y. TIMES, Mar. 25, 1963, at 12 (noting that twenty-two states filed amicus briefs requesting the Court to impose the counsel requirement in all serious criminal cases in the states). 
reform. ${ }^{252}$ A survey of public opinion from the 1964 election in which Goldwater sought to make crime an issue suggested the issue barely registered on the public consciousness. ${ }^{253}$ As late as 1965 then-ABA President Lewis Powell, concerned about statistics demonstrating growing crime, could write, "Americans by and large seem apathetic about the crime situation. ${ }^{254}$ But a steady increase in the crime rate was reported during the second half of the 1960s, growing at a rate of five, or six, or even nine times the population growth rate. ${ }^{255}$ The disjuncture between a growing crime rate and increased rights for suspects was telling. ${ }^{256}$ As Professor Herbert Packer would observe, "Middle class city dwellers, appalled by the Hobbesian jungle around them, are beginning to wonder if the pendulum has not swung too far.,257

252. See Homer Bigart, Kennedy Hails High Court, N.Y. TMmES, Sept. 21, 1964, at 1 (reporting former Attorney General Robert F. Kennedy's observation that "the Court's recent landmark decisions on criminal law, race relations and apportionment of state legislature[s] showed the way to a just and responsible society"). But see Cabell Phillips, Katzenbach Links Street Riots to Crime Rise, Not Rights Drive, N.Y. TimEs, Sept. 19, 1964, at 17 (quoting acting Attorney General Nicholas Katzenbach, who stated that "[t]o tie the difficult problems of racial adjustment to the equally serious problems of crime and delinquency ... can only obscure, obstruct and politicize"). See generally Michael J. Klarman, The Racial Origins of Modern Criminal Procedure, 99 MICH. L. REV. 48, 93 (2000) (describing "landmark criminal procedure cases" as "consonant with dominant national opinion at the time," and as "exemplify[ing] the paradigm of judicial imposition of a national consensus on resistant state outliers (with the qualification that even the southern states generally accepted these norms in the abstract)"); Klarman, supra note 138, at 62-64 (discussing the relationship between race discrimination, poverty, and early criminal procedure decisions).

253. See Murphy \& Tanenhaus, supra note 217, at 35-36 ("The Supreme Court's decisions on reapportionment and on the rights of defendants in criminal cases, the two subjects that Goldwater assailed most frequently and stridently, were barely visible to the public at large.").

254. Lewis F. Powell, Jr., An Urgent Need: More Effective Criminal Justice, 51 A.B.A. J. 437,438 (1965).

255. Concern About Confessions, supra note 64, at 53 (noting that the crime rate was rising five times faster than the rate of population growth); The Cops v. the Courts, TrME, Aug. 28, 1964 , at 59 ('U.S. police and prosecutors [complain that] 'misguided courts' are 'handcuffing' effective law enforcement ... at a time when U.S. crime is rising five times as fast as the population."); Nixon Denounces Humphrey Views, N.Y. TIMES, Sept. 7, 1968, at 1 (quoting Nixon, who noted that the crime rate is rising nine times faster than the population); Herbert Packer, Policing the Police, NEw REPUBLIC, Sept. 4, 1965, at 17 (reporting in 1965 that since 1958 the number of criminal offenses had increased six times as fast as the population).

256. See, e.g., Chamberlain, supra note 64 , at 32 (noting the tension between the restraints a society may impose for its own security and the upholding of rights of individuals in that society); Concern About Confessions, supra note 64, at 52 (noting the difficulty in balancing "the safety of society against the rights of the individual"); Fred P. Graham, Shift in Court's Trend, N.Y. TIMES, June 14, 1967, at 32 (noting the Court's "politically hazardous business of liberalizing the rights of criminal suspects ... despite the apparent rise of public sympathy for politicians' anticrime proposals"); Rewriting the Rules, supra note 64, at 21 ("[T] rate of crime--and ... police themselves felt lonelier and more beleaguered than ever as a check against that tide. Predictably, it set off a battery of angry dissents within the Court-and a coastto-coast howl of protest from the cops.").

257. Packer, supra note 255, at 17; see also FRED P. GRAHAM, THE SELF-INFLICTED WOUND $4(1970)$ (noting the "coincidence" between the simultaneous rise in "crime, violence and racial tensions in the United States and the Supreme Court's campaign to strengthen the rights of 
The storm broke most notably over the bête noir of criminal justice reform, Miranda. Despite some suggestion that Miranda's impact might be limited, ${ }^{258}$ the reaction of many ranged from angry to apoplectic, ${ }^{259}$ the most popular metaphor perhaps being "handcuffing the police.".260 More than one commentator leveled old-fashioned, garden-variety countermajoritarian charges, among them the editorial board of the New York Times. ${ }^{261}$ As an

criminal suspects against the state"); Don't Say a Word, Mac, NAT'L REV., June 28, 1966, at 606 ("No reference at any point to what is going on in the highways and byways of our jungle-cities. Better that ten thousand rapists go free than that one confession should be obtained without benefit of attomey!").

258. See Bickel, Crime, Courts, supra note 197, at 9 (noting that studies subsequent to the Miranda decision indicate that the "“overwhelming majority of cases ... are disposed of by pleas of guilty" and speculating either that Miranda "do[es] not significantly increase the difficulty of obtaining confessions, or confessions are not all that significant" (citations omitted)); Fred P. Graham, General Reaction Is Mild, N.Y. TIMES, June 15, 1966, at 1 (reporting that Director of National Crime Commission James Vorenberg stated that the Miranda ruling "might not... substantially change[]" the standard for deciding on the admissibility of confessions); Rewriting the Rules, supra note 64, at 22 (stating that dissent among police and prosecutors toward the Miranda decision was "by no means unanimous" since many departments had begun implementing similar "safeguards into the integration process").

259. Compare Graham, supra note 258 ("Reaction across the nation to [Miranda] was regarded in legal circles . . a mild."), with New Rules for Police Rooms, TIME, June 24, 1966, at 54 (noting the emphatic reactions of various police officials, among which were: "[T]here is being developed sophisticated law for an immature society."), and id. ("It's the damnedest thing I ever heard-we may as well close up shop.").

260. See Bickel, Crime, Courts, supra note 197, at 8 (noting that the Supreme Court's decisions have created a "barbed wire of legalisms" that gives the " green light' to "the criminal elements" (quoting Richard Nixon)); Fred P. Graham, Marshall and the Activists, N.Y. TIMES, Sept. 3, 1967, at 12 (noting West Virginia Senator Robert C. Byrd's criticism of the Court's decisions as those which "handcuff the police"); Rewriting the Rules, supra note 64, at 22 (quoting a Philadelphia detective's claim that the decision "puts the police ... out of business"). Polls administered in 1969 reflect public sentiment that Supreme Court decisions had contributed to the increase in crime. See LOUIS HARRIS \& ASSOCS., HARRIS 1969 GOVERNMENT SURVEY, No. 1905 (Mar. 1969), at http://www.irss.unc.edu/data_archive/pollsearch.html (finding that, based on a national sample of persons twenty-one or older, $50.4 \%$ of respondents believed that U.S. Supreme Court decisions protecting the rights of accused offenders were a major cause of the increase in crime, $22.5 \%$ felt it was a minor cause, $15.0 \%$ felt it was hardly a cause, while the remaining 12.2\% were unsure); LOUIS HARRIS \& ASSOCS., HARRIS 1969 URBAN CRIME SURVEY, No. 1935 (May 1969), at http://www.irss.unc.edu/data_archive/pollsearch.html (reporting that, in a survey conducted for Life, based on a national sample of persons twenty-one years or older, who were asked, "Some people have said that recent Supreme Court decisions have 'handcuffed' the police and made their job more difficult, while others feel the court decisions have strengthened the rights of individuals and still left the police with enough authority to do their job properly. In general, do you feel the police have too little authority to do their job properly, do you feel they have the right amount of authority ... or do you think they actually have too much authority?" $49.1 \%$ of respondents felt the police had "too little authority," $36.5 \%$ felt they had the right amount of authority, and $6.3 \%$ felt they had too much authority); George C. Wallace, Campaign Speech (Oct. 24, 1968), in CAMPaign SPEeches OF AMERICAN PRESIDENTIal Candidates, 1948-1984, at 185, 188 (Gregory Bush ed., 2d ed. 1985) ("The Supreme Court of our country has hand-cuffed the police ....").

261. Editorial, Freely and Voluntarily, N.Y. TIMES, June 15, 1966, at A46 (describing the Court's actions as a "deep excursion into lawmaking"). The New York Times editorial on Miranda was a frontal assault on the Court. Regretting that the Court had not limited itself to "enunciating ... sound doctrine" that confessions be voluntary, the editorial went on to state that 
article in the Reader's Digest explained, "If nothing is done, we will live under a system prescribed not by elected representatives but by a committee of five lawyers sitting in a faraway marble palace and unaccountable to anyone at the ballot box for the results of their legislating." 262 It was not just the popular press, however; the decisions were so reviled that judges too got into the act of criticizing the Court. Witness this parody of the Supreme Court speaking to the public, from a reported state court decision: "You don't count. Your situation doesn't count. History doesn't count. The states don't count. Congress doesn't count. Only our decision by five or more justices counts!"263 The title of Fred Graham's book on Miranda-The SelfInflicted Wound-said it all. ${ }^{264}$

Yet, despite rampant public dissatisfaction, criminal rights remained an area where academic support for the Court remained fairly strong. In a sense, these cases presented the classic countermajoritarian difficulty. The public was greatly opposed, and the rights at stake were those that later history suggests find little in the way of public support. With the Court forcing itself upon an unhappy public, one would reasonably expect the academic proponents of the countermajoritarian problem to speak up in those terms. But, as it happens, they did not, indicating yet again that the countermajoritarian problem that plagued the academy was not one that reflected an accurate view of the realities of judicial review. Bickel himself approved of decisions like Miranda. ${ }^{265}$ Others were concededly more confused, as their general disapproval of the Warren Court collided with what they seemed to know were the right results. Thus, Philip Kurland would complain about federal standards and federalism, even while acknowledging the "deep and dangerous cancers" in the state court treatment of these issues, indicating implicit agreement with the decisions, if not tacit support. ${ }^{266}$ Complaints about the craft of the Court in this area

the Court had "incorporated in its opinion remarks that could only be interpreted as downgrading the reliability and worth of all confessions-remarks lacking either constitutional warrant or constructive effect in the administration of justice." Id; see also Bickel, Warren Court, supra note 197, at 131 ("[T] he Court took on a job [in Miranda] that legislatures and other agencies might better have been allowed to do first...."); Eugene H. Methvin, Is the Supreme Court Really Supreme?, READER's DiG., July 1967, at 80, 85 [hereinafter Methvin, Is the Supreme Court Really Supreme?] ("The time has come for our elected representatives to blow the whistle [on the Court]."); Eugene H. Methvin, Let's Have Justice for Non-Criminals, Too!, READER's DiG., Dec. 1966, at 53, 56 [hereinafter Methvin, Let's Have Justice] ("The judges have left the public behind ...."' (quoting Attomey General Nicholas Katzenbach)).

262. Methvin, Let's Have Justice, supra note 261, at 60.

263. State v. Puckett, 201 N.E.2d 86, 89 (Ohio C.P. Paulding County 1964).

264. GRAHAM, supra note 257.

265. See Alexander M. Bickel, THE Supreme Court AND the IdEA OF Progress 49 (1970) (calling Miranda a "radical, if justifiable, departure from prior practice"); Bickel, Crime, Courts, supra note 197, at 8 (critiquing Nixon's attack on Miranda).

266. Kurland asserted:

[T] he only thing that the Warren Court has done is to demand that the state criminal processes come up to the same standards that are being imposed on federal criminal 
were common, but they typically were sandwiched in among support for the venture itself. ${ }^{267}$

The political effect of the criminal rights reform effort was to lower public support for the Court, and to make it a pawn in the 1968 election. Following Miranda, the Court slowed its reform effort, and handed down a number of pro-police decisions, but it had not acted quickly enough. ${ }^{268} \mathrm{~A}$ variety of polls showed that in the 1967-1968 period the Court tumbled to its lowest recorded levels in popular opinion, with unfavorable reactions outnumbering favorable ones. ${ }^{269}$ Richard Nixon challenged that "some of our courts in their decisions have gone too far in weakening the peace forces as against the criminal forces."

processes. ... The problems of anti-Negro discrimination and the crudities of criminal procedure in the states were deep and dangerous cancers in our body politic. They called for drastic action.

KURLAND, supra note 175, at 82-83.

267. See MCCLOSKEY, supra note 63, at 246 ("Whatever the infirmities of the reasoning ... the 'Mapp doctrine' takes an important place among the rules that insure uniform fair play to the individual .... Other decisions of the term ... add to the impression of judicial resolution in this field [expanding protections for criminal suspects]."); Archibald Cox, The New Dimensions of Constitutional Adjudication, 51 WASH. L. REV. 791, 829 (1976) (noting that the Warren Court "brought more nearly equal justice into the criminal courts").

268. Isidore Silver, Stop and Frisk, COMMONWEAL, July 12, 1968, at 455, 456 (noting that pro-police decisions such as Terry were "examples of the Court's tendency to follow (or perhaps forecast) the election returns," which demonstrates that the Court would not "defy ... public opinion").

269. See RICHARD HARRIS, THE FEAR OF CRIME 110 (1968) (stating that, according to a 1968 Gallup Poll, "unfavorable feelings toward the Court outweigh favorable sentiment by a 3-to2 ratio"); MARSHALL, supra note 217, at 139 fig.6.1 (reporting that, according to a Gallup Poll, between 1967 and 1969, people whose opinion of the Court was "excellent" or "good" dropped from $45 \%$ to below 35\%); Is Supreme Court Losing Popularity?, U.S. NEWS \& WORLD REP., July 22, 1968, at 9 (reporting that, according to a 1968 Gallup Poll, the percentage of polled individuals giving the Supreme Court an unfavorable rating rose from $46 \%$ in 1967 to $53 \%$ in 1968).

270. Richard M. Nixon, Acceptance Speech (Sept. 1, 1968), in 20 VITAL SPEECHES OF THE DAY 676 (1968). In a New York City campaign speech, George Wallace stated:

We have a sick Supreme Court.... [The Court has] hand-cuffed the police, and tonight if you walk out of this building and are knocked in the head, the person who knocks you in the head is out of jail before you get in the hospital, and on Monday morning, they'll try a policeman about it.

Wallace, supra note 260 , at 188 . In a preelection statement, Nixon singled out the Escobedo and Miranda decisions directly. See Bickel, Crime, Courts, supra note 197, at 8-9 (quoting Nixon as regarding the Miranda decision as "very nearly rul[ing] out the 'confession' as an effective and major tool in prosecution and law enforcement"); Three Candidates Speak Out on Three Big Issues, U.S. NEWS \& WORLD REP., May 20, 1968, at 98 ("The Miranda and Escobedo decisions of the High Court have had the effect of seriously hamstringing the peace forces in our society and strengthening the criminal forces...." (quoting Richard Nixon's statement of May 9, 1968)); see also James T. Wooten, Politics: 16,000 in Madison Square Garden Cheer Wallace's Third-Party Candidacy, N.Y. TIMES, Oct. 25, 1968, at 32 (describing Wallace's presidential campaign speech in which he launched vitriolic attacks on the Supreme Court and Attorney General for the civil 
Vietnam war were "the only two issues that ... mattered to most voters this year" and on the crime issue Nixon held a huge lead over Humphrey. ${ }^{271}$

Nixon won the election in part based upon his anti-crime, anti-Court stance, and change was in the air. Earl Warren retired. A lame-duck Lyndon Johnson had nominated Abe Fortas to take the Chief's chair, a nomination that raised a congressional storm even before Nixon's election. ${ }^{272}$ Fortas's nomination was defeated; it is hard to say whether this was because of his identification with the Warren Court's more liberal decisions, especially in the crime area, or because of his more personal dealings. ${ }^{273}$ After Fortas resigned from the Court in the face of ethical questions, ${ }^{274}$ Richard Nixon was left with two seats to fill. One, the Chief Justice's, went to Warren Burger, who had earned his place on the Court, it seems, by attacking the very same criminal justice decisions of the Warren Court that Nixon had pilloried. ${ }^{275}$ And so the Warren Court became the Burger Court, and Courtwatchers believed an era was coming to an end.

\section{SUBTEXT}

The historical narrative of the preceding Part reveals two things. First, as theory suggests ought to be the case during this period, public reaction to the Court closely mirrored what the Court actually was doing. Specifically, when the Court was interfering with popular will, then countermajoritarian criticism was heard. When some group less than a majority disapproved of

rights cases, accusing them of kowtowing to "left-wing intellectuals and communist professors who advocate victory for the Vietcong").

271. Robert H. Phelps, Humphrey's Dilemma, N.Y. TimES, Sept. 13, 1968, at A52.

272. For an excellent biography of Abe Fortas, see LAURA KALMAN, ABE FORTAS (1990).

273. See id.; see also Laura Kalman, Abe Fortas: Symbols of the Warren Court, in THE WARREN COURT IN HISTORICAL AND POLITICAL PERSPECTIVE, supra note 184 , at 155 . First, once on the bench, Fortas remained a close friend of President Johnson and consulted with him regularly on political issues such as speeches and campaign strategy. Second, he had arranged to receive an annual "consulting" fee for more than half of his judicial salary from the Wolfson Family Foundation, an organization whose director was under investigation by the Securities and Exchange Commission at that time. Although Fortas ultimately backed out of the contract, he could not avoid the image of unethical conduct. See KALMAN, supra note 272.

274. See Fred P. Graham, Fortas Quits the Supreme Court, N.Y. TimES, May 16, 1969, at 1; see also Jeffrey K. Tulis, Constitutional Abdication: The Senate, The President, and Appointments to the Supreme Court, 47 CASE W. RES. L. REV. 1331, 1344-45 (1997) (describing Justice Fortas's behavior that cast him in a veil of impropriety, ultimately causing his resignation).

275. See Rights and Wrongs of U.S. Justice, READER's DIG., Aug. 1969, at 84 (noting in the editor's introduction to Warren Burger's piece that one of the factors that influenced Nixon's nomination of Burger as Chief Justice was his "penetrating analysis of [the] criminal justice system"); Robert B. Semple, Jr., Nixon Influenced by Fortas Affair in Court Choices, N. Y. TIMES, May 23, 1969, at 26 (reporting that Nixon conceded that "he had selected Judge Burger in large part because the judge had shared his view that the Constitution should be rigorously interpreted and, specifically, his view that the Court may have gone too far in broadening the rights of suspects in criminal cases"). 
the Court's work, criticism was framed otherwise, such as in states' rights terms. When the Court rendered popular decisions, the public applauded.

But second, and importantly, academic criticism of the Supreme Court tracked neither that of the broader public, nor what the Court actually was doing. As Part III has made clear, it often deviated in perverse ways. Academics criticized the reapportionment cases in countermajoritarian terms, despite their popularity with the public, and the political lockup that made curing the problem through ordinary majoritarian political channels impossible. Yet academics approved of Miranda, so that when countermajoritarian criticism would have been appropriate, it was absent or muted. This divergence of academic commentary and public opinion, unique to the period, betrayed very real and poignant concern in the academic mind about the endeavor of judicial review itself.

This is the period in which the modern-day obsession with the countermajoritarian problem was born. As this Part will explain, midcentury academics were not tackling an ageless problem that had baffled scholars for decades. They were not even fighting the same fights as their Progressive Era forebears. Rather, these academics simply were displaying anxiety about a set of circumstances somewhat unique to their times. They were a group of scholars who claimed approval of the results of a liberal Court, ${ }^{276}$ but felt uncomfortable doing so given longstanding liberal opposition to active judicial review. Given recent history, those academics also feared for the safety of an activist Supreme Court. Academics

276. One cannot discount entirely the possibility that what motivated the academic debate, at least at times, was simple disagreement with the Warren Court on the underlying merits of its decisions. For example, Skelly Wright would comment that "[i]t is useful . . to pierce the veil of the scholarly tradition and to see its quarrel with the Warren Court for what it really is. It is, I believe, a fundamental dispute over the good society as well as over judicial method." J. Skelly Wright, Professor Bickel, the Scholarly Tradition, and the Supreme Court, 84 HARV. L. REV. 769, 803 (1971). And Robert McCloskey similarly discounted criticisms of the Warren Court's pace: "[T]heir description has often been suspect because they so obviously object to the aims of the Court's activism rather than to the activism itself." MCCLOSKEY, supra note 63, at 326; see also Isidore Silver, The Warren Court Critics: Where Are They Now That We Need Them?, 3 HASTINGS CONST. L.Q. 373, 378 (1976) (suggesting that some critics' pleas for greater craftsmanship "served to cloak disagreements with the substantive decisions of the Warren Court"). Yet, despite skepticism about the values of some critics, many professed approval of the results of Warren Court decisions, if not the methodology, and defenders like Charles Black seemed at times willing to take them at their word. See BICKEL, supra note 265, at 49 (calling Miranda a "radical, if justifiable, departure from prior practice"); BLACK, supra note 1, at 172. More important, the countermajoritarian difficulty came to grip a host of academics who-if nothing else is clear-had wide admiration for the Warren Court. See, e.g., WECHSLER, supra note 190, at 43 (noting with respect to Brown that "for one of my persuasion [the school decision] stirs the deepest conflict I experience in testing the thesis I propose. Yet I would surely be engaged in playing Hamlet without Hamlet if I did not try to state the problems that appear to me to be involved."); Philip B. Kurland, Toward a Political Supreme Court, 37 U. CHI. L. REV. 19, 46 (1969) ("The Nixon Court has awesome tasks before it: To match the Warren Court aspirations for the protection of individuals and minorities that today justifies the Court's existence. To restore the confidence of the American public in the rule of law. One or the other is not enough."). 
expressed their anxiety in the terms they did, not because those terms made sound descriptive sense, but because the rhetoric was inherited from a set of teachers who in fact had tried to discipline (not justify) judicial review during the first forty years of the century. Thus, the primary criticism of judicial review as countermajoritarian, so familiar to today's ears, was an accident of historical forces, not an empirically accurate description of the problem those academics faced. Understanding the historical contingency of this description of judicial review ought to free us up to study and theorize about judicial review more directly and accurately in our own time.

\section{A. The Long Shadow of the Progressive Era}

This story necessarily begins in the Progressive period at the turn of the twentieth century-more familiar to legal academics as the Lochner era. During that era, progressive academics attacked the courts for invalidating legislation enacted to ameliorate the economic pains of industrialization and assure a certain amount of social welfare to those displaced by the changing economy. ${ }^{277}$ Few of the obsessed actually cut their teeth during the Progressive Era battles, but their most important teachers, notably Learned Hand and Felix Frankfurter, did. ${ }^{278}$

Two aspects of the Progressive Era attack on the courts played an integral role in the development of mid-century's fixation on the countermajoritarian problem. The first was the central claim of the Progressive Era: The courts were acting inappropriately by interfering with the will of the people-the "countermajoritarian criticism." ${ }^{279}$ The second was the insight that ultimately led to that critique, an insight that would later come to bear the name Legal Realism. ${ }^{280}$ In its plainest and most uncluttered form, the insight was that the dictates of constitutional law are relatively indeterminate, and that therefore judicial ideology necessarily would have a significant impact on legal outcomes. ${ }^{281}$

277. Friedman, supra note 6.

278. Carl Landauer explains:

To many in Hand's audience in 1958, the story of the Progressive Party must have seemed like ancient history. Yet it figured quite prominently in Hand's personal history, for it was as a Progressive Party candidate that he ran unsuccessfully in 1913 for a seat on the New York Court of Appeals, and a year earlier he had been involved in the drafting of the party's platform in Teddy Roosevelt's bid for the presidency. It was, then, the spirit of Progressivism that Hand invoked in his attack on the Warren Court.

Carl Landauer, Scholar, Craftsman, and Priest: Learned Hand's Self-Imaging, 3 YaLE J.L. \& HUMAN. 231, 236 (1991) (citation omitted); see also H.N. HIRSCH, THE ENIGMA OF FELIX FRANKFURTER 11-64 (1981) (discussing Frankfurter's early development as a Progressive).

279. See infra notes $282-285$ and accompanying text.

280. See infra notes 306-310 and accompanying text.

281. See infra notes $306-319$ and accompanying text. 
At mid-century, however, there was plenty of room to question how apt the premises were that had shaped countermajoritarian criticism during the earlier era. Two factors, in particular, deserve examination. First, as a descriptive matter, it was anything but clear that the mid-century Court was interfering with popular will in the way this criticism was meant during the Progressive Era. Second, by the 1940s the public had achieved some comfort with the Realist insight, and in any event there was at least one very popular legal and political theory to justify the work of the midcentury Court. Understanding the differences between early and midcentury - and why the earlier criticism no longer was quite apt-sets the stage for seeing precisely what was gripping mid-century academics.

\section{The Problem with the Countermajoritarian Problem at Mid-Century}

Countermajoritarian criticism made much sense during the Progressive Era. First, there were instances in which the courts plainly attacked laws with wide majoritarian support, such as the invalidation of the income tax and the overturning of child labor legislation. At the least, these were measures that had made their way through legislative bodies, only to be struck down in relatively short order by the courts. ${ }^{282}$ Second, there was a democratic fervor sweeping the country at the time, and legislatures were deemed to be infinitely more responsive to the popular will than judges, who were seen as class-biased ideologues manning the barricades against what conservatives viewed as the mob. ${ }^{283}$ Add to this the realization that the Constitution was capacious enough for constitutional cases to come out either way-indeed, different judges often saw them quite differently ${ }^{284}$ and it became perfectly sensible to express concern that often-unelected judges were trumping the will of the populace. No wonder that the period between 1890 and 1925 saw countermajoritarian criticism leveled at courts more often than at any other time in history. ${ }^{285}$ During the Progressive Era, such countermajoritarian criticism captured accurately the problem with judicial review that Progressives experienced.

By mid-century, however, the world looked quite different than it had during the Progressive Era, calling into question just how apt the earlier era's criticism really was. No one stumbled around this quite as much as

282. See Friedman, supra note 6 , at 1391-96. There is a large body of revisionist scholarship about the Lochner era that makes much of the fact that Progressive Era courts upheld far more laws than they struck down. The difficulty with these arguments is that it was the invalidating cases that captured the public's mind. For a description of this revisionist literature, and an argument about which cases were important, see $i d$. at 1448-52.

283. Id. at $1432-36$.

284. Id. at 1451 .

285. Id. at $1438-47$. 
Bickel; through the eyes of his own struggle we can begin to see the emergence of the countermajoritarian obsession. A quarter century ago, Edward Purcell put it well, "In spite of its intricate and finely-honed arguments, The Least Dangerous Branch was riven by serious problems. The treatment of Supreme Court 'deviance' seemed exaggerated and ultimately unconvincing." ${ }^{286}$ Indeed, both halves of the overly simple model Bickel presented in The Least Dangerous Branch were problematic: the majoritarian nature of ordinary politics and the behavior of the Supreme Court.

Neither political scientists nor the broader public saw democracy in the majoritarian terms Bickel used. ${ }^{287}$ In the political science literature, both pluralism and majoritarianism were offered and debated as theories of American democracy. ${ }^{288}$ Some pluralists saw political life as a healthy interaction among competing groups. Others saw dysfunction in interest group politics. But at no time were there the sweeping calls for majoritarian democracy that fueled the countermajoritarian critique during the Progressive Era.

Indeed, Bickel's own view of democracy was not entirely consistent with his formulation of the countermajoritarian problem. Bickel seemed to rely on a majoritarian model of democracy only when it was juxtaposed with judicial review. ${ }^{289} \mathrm{He}$ often "acknowledged that American government

286. Edward A. Purcell, Jr., Alexander M. Bickel and the Post-Realist Constitution, 11 HARV. C.R.-C.L. L. REV. 521, 537 (1976); see also KALMAN, supra note 2, at 39 ("Bickel's concept of democracy was both populist and simplistic."); Mark Tushnet \& Timothy Lynch, The Project of the Harvard Forewords: A Social and Intellectual Inquiry, II CONST. COMM. 463 (1994).

287. See supra notes $59-66$ and accompanying text.

288. For discussions of pluralism, see V.O. KeY, JR., Politics, Parties and Political PRESSURE GROUPS 23, 145 (1942) ("At bottom, group interests are the animating forces in the political process. ... An act of a legislature may be in reality only the ratification of an agreement negotiated by the representative of those private groups with an interest in a specific question."); EARL LATHAM, THE GROUP BASIS OF POLITICS 36 (1952) ("[P]ublic policy... represents a balance which contending factions ... constantly strive to weight in their favor."); and Robert Dahl, Decisionmaking in a Democracy: The Supreme Court as a National Policy-Maker, $6 \mathrm{~J}$. PUB. L. 279, 294 (1957) ("Generally speaking, policy at the national level is the outcome of conflict, bargaining, and agreement among minorities; the process is neither minority rule nor majority rule but... minorities rule, where one aggregation of minorities achieves policies opposed by another aggregation."). For a discussion of majoritarianism, see DONALD C. BLAISDELL, AMERICAN DEMOCRACY UNDER PRESSURE 16 (1957) ("As twin features of the American creed, individual rights and majority rule are always in an uneasy balance."). For a discussion of differing notions of "democracy" held by academics at the time, see KALMAN, supra note 2, at 25-26. For a detailed contemporary discussion of pluralism, see generally STEPHEN M. FELDMAN, AMERICAN LEGAL THOUGHT FROM PREMODERNISM TO POSTMODERNISM (2000).

289. Compare BICKEL, supra note 16, at 17 (arguing that when the Court declares a legislative or executive action unconstitutional, it exercises control against a prevailing majority), id. ("[A] representative majority has the power to accomplish a reversal."), and id. at 18-19 (noting that even when interest groups exercise power "only those minorities rule which can command the votes of a majority of individuals in the legislature who can command the votes of a majority of individuals in the electorate"), with BICKEL, supra note 265 , at 35 (criticizing the reapportionment decisions for being "simplistically populist" and ignoring attention to "minority 
was not "majoritarian." 290 Discussing the reapportionment decisions, Bickel argued at length that American constitutional democracy was not intended to be majoritarian, pointing to the Senate and insisting that "we don't choose to do everything by simple majority vote."291 His primary example in attacking the notion of majoritarianism was the Court. $\mathrm{He}$ argued, "The American government-as Chief Justice Warren might have been expected to remember; nothing is stranger than a populist judge!includes a Supreme Court.",292 "In truth," Bickel continued,

these institutions and devices tell us that throughout our history we have perceived other values of government than mere responsiveness to simple majorities of the moment, which are in any event not easy to find and are as often imaginary as real; and we have defined democracy as the rather complex sum of these values, not just as uncompromising majoritarianism. ${ }^{293}$

In his last book, Bickel concluded that the consent of the people is yielded not to "numerical majorities" or even in "elections" but "to institutions validated by time and familiarity and composed from time to time of men who are trusted because they are seen to have 'a connexion with the interest ... the sentiments and opinions of the people. ${ }^{1,294}$ One might have said the same for the Supreme Court.

Moreover, as should be obvious already, it was far from clear that the mid-century Court was the countermajoritarian institution Bickel painted it as being. ${ }^{295}$ Dahl, upon whom Bickel relied for much of his pluralist theory of democracy, had written an important article in 1957 explaining that the decisions of the Court are rarely contrary to the views of the dominant

representation" and "the distribution of access and power among various groups"), and ALEXANDER M. BICKEL, THE MORALITY OF CONSENT 17 (1975) ("The people are something else than a majority registered on election day .... The people begin with 'the little platoon we belong to in society,' what today we call groups, and they are found in places to which they are attached ....").

290. Purcell, supra note 286, at 537; see also BICKEL, supra note 265, at 112-15 (discussing the Madisonian tradition).

291. Alexander Bickel, The New Supreme Court: Prospects and Problems, 45 TUL. L. Rev. $229,241(1971)$.

292. Id.

293. Id. at 242.

294. BICKEL, supra note 289, at 18 (quoting Edmund Burke).

295. On this point, Howard Dean asserted:

Some criticisms of judicial review as undemocratic rest on the assumption that there is a unified and determinate "popular will" or "majority will" which is frustrated when the Supreme Court decides that a statute is unconstitutional... But obviously this conception of the common will is [a] vast oversimplification [which] ... obscures the fact that ours is a highly pluralistic, "multigroup," "associational" society.

DEAN, supra note 210 , at 55 . 
political majority. ${ }^{296}$ Even Brown, Mark Tushnet points out, "was, in the political sense, an act by one part of the governing coalition against another. ${ }^{297}$ This view was hardly an obscure one in the legal academy; many commentators made the point that judicial power ultimately depended upon popular acceptance. ${ }^{298}$ Indeed, Bickel made the point himself, repeatedly. ${ }^{299}$ But Bickel's countermajoritarian concern is thus a little puzzling: As the discussion in Part III suggested, many of the Court's decisions were met by popular acceptance, if not support.

Moreover, in contrast to the Progressive Era's judicial overruling of democratically supported legislative action, many saw mid-century as a time of legislative stasis, and judicial intervention as a necessary force to solve the problems neglected elsewhere. The very popularity of the reapportionment decisions belied any perception that legislative bodies were reflecting popular will, and that courts were not. Throughout the period, commentators would suggest the Court actually was doing the elected branches a favor by dealing with problems these branches could not or would not face. ${ }^{300}$

296. See Dahl, supra note 288; see also Griffin, supra note 9, at 516-19 (explaining how Dahl's work undercut Bickel's argument).

297. Tushnet, supra note 184 , at 16; see also Graber, supra note 40 (making a similar argument); Klarman, supra note 138, at 6 ("[T] $[$ he court's decisions are better understood as comprising two categories. Frequently the Court takes a strong national consensus and imposes it on relatively isolated outliers. Infrequently the Court resolves a genuinely divisive issue that rends the nation in half; on these occasions, roughly half the country supports the Court's determination. Neither of these roles, it seems to me, is accurately characterized as providing 'havens of refuge for those... who are helpless, weak, outnumbered or.... are nonconforming victims of prejudice."').

298. See BLACK, supra note 1, at 209 ("[l]f public opinion had rejected it, the performance by the courts of the function of judicial review would have been impossible ... because such an institution, founded in the end only on moral authority, could never have had the strength to prevail in the face of resolute public repudiation of its legitimacy."); ROBERT G. MCCLOSKEY, THE AMERICAN SUPREME COURT 225 (1960) ("[T] he salient fact, whatever the explanation, is that the Court has seldom lagged far behind or forged ahead of America."); EUGENE V. ROSTOW, THE SOVEREIGN PREROGATIVE: THE SUPREME COURT AND THE QUEST FOR LAW 142 (1962) (commenting on reaction to the desegregation decisions and noting that " $[t]$ he Supreme Court and the Constitution it expounds cannot survive unless the people are willing, by and large, to live under it").

299. See BICKEL, supra note 16, at 252 (arguing that "[i]n an enforcement crisis of any real proportions, the judiciary is wholly dependent upon the Executive" and that the judiciary's key to obtaining executive support is a willingness to lay down principles amenable to compromise in the face of popular opposition); BICKEL, supra note 265 , at 94,95 (stating that "[t]he Court's effectiveness, it is often remarked, depends substantially on confidence" and "the Court is well advised to test public opinion"); see also BICKEL, supra note 226, at 13 (arguing that a dissenter has the right to have a court decree aimed directly at him because "he waits to allow time for the agitation of public opinion, since he knows that if he turns out to be in the majority or to feel intensely where all others are merely indifferently acquiescent he can change the law, or make it a dead letter, without recourse to the extremely cumbersome process of amendment").

300. See, e.g., CURTIS, supra note 48, at 248; PAUL A. FrEUND, ON UNDERSTANDING THE SUPREME COURT 38 (1949). 
Thus it was that even popular dissenters from Court decisions did not claim that the Court was interfering with popular will, as much as that the Court was rushing ahead of legislative (and perhaps) popular decisionmaking. ${ }^{301}$ The claims, though easily confused, are different. The countermajoritarian criticism applies to courts striking down laws that had been enacted by popular legislative bodies, at least theoretically with broad popular support. This was precisely the case during the Progressive Era, with relatively fresh legislation in constant jeopardy. During the Warren era, however, the Court's decisions typically did not invalidate newly enacted legislation. Rather, the Court moved to address social problems that already were of concern to the public. Commentators acknowledged this, and pointed to the legislative logjam that seemed to justify judicial action. Even critics did not claim the Court was trumping majority will, only that it was rushing ahead of the public.

On the latter score-rushing ahead of public opinion-the test of legitimacy is not accountability but history. The question would be, had the Court gotten it right? As Bickel himself recognized, history might vindicate the Court. His screed, The Supreme Court and the Idea of Progress, explicitly nods at the future as the ultimate test of the Court's success. ${ }^{302}$

\section{The Lingering Odor of the Realist Critique}

The Progressive Era's mantra of judicial deference to legislative judgments was a conclusion that followed from an insight that would change jurisprudence perhaps forever. That was the Realist observation that most constitutional cases were not resolved on the basis of determinate standards. ${ }^{303}$ Disagreement with Lochner era decisions brought scholars to

301. See, e.g., Alpheus Thomas Mason, The Supreme Court: Palladium of Freedom 169-70 (1962) ("The ill effects and shortcomings, if such there be, of the Warren Court's decisions can be removed by an ordinary act of Congress. It is under attack for responding to public aspirations, perhaps in moving ahead of them, as in the desegregation decisions."); Alexander M. Bickel, Close of the Warren Era, NEw REPUBLIC, July 12, 1969, at 13, 15 ("A Court ... tends to attack problems at retail, in the smallest possible compass, illuminating ultimate principles in the glare of its headlights, as it were, but seldom speeding ahead.... Speed, however, and the confident, single-minded imposition of solutions to problems of the first magnitude these have been the hallmarks of the Warren Court."); Term's End for the Court, N.Y. TIMES, June 28, 1964, at E8 (warning of the danger that the Court is "moving too swiftly," "getting too far ahead of what the country accepts as right and just," and "seeking to legislate in its own right").

302. BICKEL, supra note 265, at 99 ("But the Justices of the Warren Court placed their own bet on the furure.... If the bet pays off, whatever their analytical failings, the Justices will have won everything.").

303. As Paul Kauper explained:

These comments on Mr. Justice Black's judicial philosophy are not designed to deprecate his opinions or to belittle his contribution to the Court. ... Rather they are intended to show that the quest for constitutional certainty and objectivity in the process of constitutional interpretation is in the end a mirage. Within the world of 
see that constitutional provisions were susceptible to a variety of interpretations. In the face of that discretion in the law, and disagreement with judicial interpretations, a stance of deference to other institutions of government made perfect sense.

It would be difficult to overstate the extent to which the public and commentators had by mid-century become reconciled to Realist (or antiformalist) conceptions. ${ }^{304}$ The Progressive Era battles, and those of 1937, had 'shred the 'innocent' view [of judicial decision-making] beyond any reasonable hope of mending. The idea of judges as self-determining human beings, rather than helpless tools of constitutional logic, became a nearly universal premise of American political thinking." ${ }^{305}$ As George Braden explained, "There is no objectivity in constitutional law because there are no absolutes.... The more widely held are the values in society, the more likely the Supreme Court will hold them; the more controversial the values, the more likely the Supreme Court is to divide over them." " "[I]f it is an exaggeration to say that judicial opinion depends on judicial digestion," Henry Steele Commager conceded, arguing that the legal realists had "dealt very harshly with the whole notion of judicial objectivity," "it will not be denied that the 'mechanical' or 'phonographic' theory of jurisprudence has been completely discredited." ${ }^{307}$ Widespread commentary suggested

possible constitutional values Mr. Justice Black moves vigorously and aggressively to fashion the Constitution that ought to be

KAUPER, supra note 159 , at $49-50$.

304. See KALMAN, supra note 2, at 5 ("Once the legal realists had questioned the existence of principled decision making, academic lawyers spent the rest of the twentieth century searching for criteria that.would enable them to identify objectivity in judicial decisions."). Kalman's claim is to the legal academy, not the public. And though neither is static - and the public perhaps less so-it seems acceptance of constitutional indeterminacy was widespread in the aftermath of the New Deal, something that likely changed once Richard Nixon began his campaign for strict constructionists on the Court.

305. MCCLOSKEY, supra note 63 , at 130 . It no doubt helped foster Realist beliefs that acceptance of judicial power to interpret the Constitution occurred following the New Deal fight and before the activism of the Warren Court. See KAUPER, supra note 159, at 1-13, 20 (describing the flexibility of the Constitution, but observing-in clearly retrospective language-that "it is a natural assumption that a process of constitutional interpretation which endows nine men with ultimate power to determine the meaning of the written text drafted by the fathers is a process extremely well calculated to insure the calcification and rigidity that spell obsolescence in a relatively short period"); see also Friedman, supra note 56, at 1013-16 (explaining how the public favored the idea of a living Constitution to validate New Deal legislation).

306. George D. Braden, The Search for Objectivity in Constitutional Law, 57 YALE L.J. 571, 594 (1948).

307. COMMAGER, supra note 48 , at 44 ; see also id. at $43-44$ (noting "that questions that have evoked judicial nullification of majority will have turned on considerations of policy rather than of law, and that on these questions the legal learning of the legislative and executive departments has been entirely adequate"); Henry Steele Commager, Judicial Review and Democracy, 19 VA. Q. REV. 417, 420 (1943) (observing that "acts which have encountered judicial invalidation have in every instance required the interpretation of vague and ambiguous clauses of the constitutionclauses whose meaning is not to be determined by legal research but by 'considerations of policy'"). 
Commager was correct. ${ }^{308}$ Despite some early resistance, by the end of the 1960s even conservative commentators like Robert Bork and James Kilpatrick were acknowledging the relatively indeterminate nature of constitutional commands, although with obvious ambivalence. ${ }^{309}$ Judge Wright explained that the "revolt against formalism" had yielded a "new creed" at the root of which was the "crucial insight, now almost universally accepted, that judges are policymakers who must 'make' law by drawing on value choices which have no necessary a priori validity." 310

However, if indeterminacy was inevitable, it was-to the academic critics of the mid-century Court-also untenable. ${ }^{311}$ Here lay much of the

308. See Charles E. Clark \& David M. Trubek, The Creative Role of the Judge: Restraint and Freedom in the Common Law Tradition, 71 YALE L.J. 255, 264, 269 (1961) ("The impact of an individual judge's values and outlook on the well-documented creative growth of the law is too important a factor to be omitted from a balanced study of their work.... These new concepts of judicial objectivity, untempered by recognition of the limits of human knowledge, all contribute to an illusion which hides the real machinery of the judicial process ...."); Arthur Selwyn Miller, Notes on the Concept of the "Living" Constitution, 31 GEO. WASH. L. REV. 881, 887 (1963) ("The concept of the 'living' Constitution leaves little room for the intentions of the framerseven if by some occult process such mental attitudes could be determined."); Martin Shapiro, The Supreme Court and Constitutional Adjudication: Of Politics and Neutral Principles, 31 GEO. WASH. L. REV. 587, 598 (1963) ("[O]n the whole, the opponents of standards present a political, result-oriented, law-making court in opposition to the neutralists' apolitical, logic-oriented, law-discovering judiciary."); see also BLACK, supra note 1, at 164 ("[I]t seems very clear that, whatever may have happened in minor skirmishes, the strategic victory was the Realists'."); Frank, supra note 88, at 141-42 (recognizing that the vagueness of "due process" gives judges a "roving commission against evil without ... subjecting them to the check of elections").

309. Judge Bork referred to the Warren Court's failure to explain and justify its decisions as a "lack of 'craftsmanship"' and suggested that there is a wide belief that some Justices on the Court "decide cases not according to the criteria they cite but according to their social and political sympathies." Bork, supra note 210 , at 138,140 . He further suggested that "it is naive to suppose that the Court's present difficulties could be cured by appointing Justices determined to give the Constitution its 'true meaning,' to work at 'finding the law' instead of reforming society." Id. at 140. Similarly, James Kilpatrick remarked, "Constitutionality is like beauty; it lies in the beholder's eye; and when the beholder sits in one of those nine great swivel chairs, the eye sees what it wants to see. The Constitution ... is what the judges say it is." Kilpatrick, supra note 58, at 795. Kilpatrick further argued, however, that constitutional interpretation is supplemented by "a code of self-restraint," which the Warren Court "repeatedly abandoned." Id. at 796 ("[T] offense imputed to the Warren Court in its handling of the Constitution [is that] [t]he Court did not interpret; it amended.").

310. Wright, supra note 276 , at 773.

311. See SEBOK, supra note 62, at 113 ("[W]e seem to arrive, if we take this path, at the monstrous conclusion that reason and argument, the conscious search for justice, are in vain." (quoting Henry M. Hart, Holmes' Positivism-An Addendum, 64 HARV. L. REV. 929 (1951))). So universal was acceptance of Realist criticism that Justice Black's assertions that his decisions were constitutionally mandated were met with angry complaints about judicial "candor." See Bickel, supra note 194, at 15 ("The question remains, in a sense, one of candor, but it is more complicated than that.... [I]t is a question ... of the utility of illusions and the justifications for creating them."). In the view of critics of formalist decisions, a lack of candor could bring down the Court. See Deutsch, supra note 185, at 237 ("Insofar as the Court also has a symbolic role to play in our society ... it too is subject to the mandate of 'establishing, declaring, and appearing to live in accordance with, standards that are not of this world.' In the case of the Court, those standards require the maintenance of an appearance not only of incorruptibility ... but also of adherence to principle, to 'logic' and to neutrality."); Friendly, supra note 73, at 937 ("Especially 
problem. "The result, of course," Robert Bork began a famous law review article by observing, "is that courts are without effective criteria and, therefore we have come to expect that the nature of the Constitution will change, often quite dramatically, as the personnel of the Supreme Court changes." 312 Bork continued, "In the present state of affairs that expectation is inevitable, but it is nevertheless deplorable." ${ }^{n 13}$ As Philip Kurland explained, "[I]f the meaning of the Constitution is as fluid as the personal whims of the Court's membership would make it, it is really no constitution at all." ${ }^{314}$ This problem of constitutional indeterminacy and concomitant judicial power went to the "heart of the difficulty which ... has been the chief cause of scholarly and professional dubiety as to the Court's role.",315 Realism, if it be true, said Bickel, is a reality "on which we cannot allow the edifice of judicial review to be based, for if that is all judges do, then their authority over us is totally intolerable and totally irreconcilable with the theory and practice of political democracy.",316

And yet, academic turmoil at mid-century over the indeterminacy of constitutional law and the discretion it provided judges was still curious when compared to the consternation over this issue during the Progressive Era. Certainly the public at mid-century saw the problem quite differently than it had at the turn of the century. During the Progressive Era constitutional indeterminacy widely was thought a bad thing: Combined with formalist decisionmaking, it permitted judges to deny economic necessity and further their class interests. ${ }^{317}$ By the time of the New Deal, however, the public had come to see such indeterminacy as a good thing, permitting judges to update the Constitution to keep up with the times. ${ }^{318}$

in constitutional adjudication, 'an unwillingness to face the responsibility of judicial freedom in the name of a spurious objectivity may also cripple the exercise of creativity." (quoting Clark \& Trubek, supra note 308, at 270)). But see Paul J. Mishkin, The Supreme Court, 1964 TermForeword: The High Court, the Great Writ and the Due Process of Time and Law, 79 HARV. L. REV. 56, 62 (1965) (stating that the proposition that courts simply declare the law and do not exercise any creativity expresses a "symbolic concept of the judicial process on which much of courts' prestige and power depend"); Shapiro, supra note 308, at 601 ("The distinction between what the Court says to the public about what it is doing and what scholars say to one another about what it is doing must be held firmly in mind.").

312. Robert H. Bork, Neutral Principles and Some First Amendment Problems, 47 IND. L.J. 1,1 (1971).

313. Id.

314. Philip B. Kurland, 1970 Term: Notes on the Emergence of the Burger Court, 1971 SUP. CT. REV. 265, 265.

315. BLACK, supra note 1 , at 166.

316. BICKEL, supra note 16, at 80 ; see also Louis Jaffe, Letter to the Editor, N.Y. TIMES, Dec. 6, 1964, $\$ 6$ (Magazine), at 22 ("Since the phrases of the Constitution are too vague to give clear guidance, the judges may end up by imposing upon the nation their will or the will of a narrow majority.").

317. Friedman, supra note 6 , at 1402-28.

318. Friedman, supra note 56 , at 1011-19 (elaborating at length upon this point). 
The precise critique of the New Deal judges was that they were "old men" refusing to do just this. ${ }^{319}$

Moreover, even if indeterminacy were a problem, it did not take the Court-or at least those Justices so disposed-long after 1937 to come to a possible solution. ${ }^{320}$ Justice Stone identified it as early as 1938 in his famous Carolene Products footnote. ${ }^{321}$ In that footnote, Justice Stone stated that more searching judicial review might be appropriate when specific textual protections were at issue, ${ }^{322}$ when legislation interfered with the functioning of the political process and the ability to find redress there, or when the rights of "discrete and insular" minorities were at stake. ${ }^{323}$ In particular, as John Hart Ely would explain, "process theory" could be pressed into service to explain many of the Court's liberal decisions of midcentury. ${ }^{324}$

It is important to understand that many Justices and scholars found the standards in the Carolene Products footnote-especially the political process argument - sufficient to solve the problem of the double standard

319. Id. at 1019-22.

320. See AlPheus Thomas Mason, The SUPREME COURT From TAFT to Burger 145-46 (1979) (indicating that in early post-1937 decisions covering civil liberties, the Court began to formulate explicitly the preferred freedoms or preferred position doctrine, which applied most especially to the First Amendment). This is the central theme of Kurt Lash's article, The Constitutional Convention of 1937: The Original Meaning of the New Jurisprudential Deal, 70 FORDHAM L. REV. 101 (2001). Lash argues that "[f]rom the perspective of the Supreme Court, the New Deal Revolution was not about embracing Rooseveltian Progressivism, it was about reestablishing the legitimacy of judicial review in the modem world." Id. at 105 . At the heart of that effort was Carolene Products, born of "preferred freedoms," id. at 158-61, and emphasizing text, $i d$. at 151, and political process, $i d$. at 152-58.

321. United States v. Carolene Prods. Co., 304 U.S. 144, 152 n.4 (1938); see also CARL BRENT SWISHER, THE SUPREME COURT IN MODERN ROLE 175 (1958) (asserting that the protection of civil liberties got "its formal start in a footnote to a case decided in 1938"). For discussions of Carolene Products, see Dowling, supra note 116, at 1176; Hamilton \& Braden, supra note 47, at 1352-54; Lusky, supra note 92, at 33-35; and Thomas Reed Powell, Conscience and the Constitution, in DEMOCRACY AND NATIONAL UNITY 1, 19 (William T. Hutchinson ed., 1941).

322. See William E. Forbath, The New Deal Constitution in Exile, 51 DUKE L.J. 165, 179 (2001) (discussing this aspect of the New Deal settlement).

323. Carolene Prods., 304 U.S. at $152 \mathrm{n.4}, 153$; see also CAHILL, supra note 159, at 93 (noting that " $[t]$ he difficulty which later writers have had in interpreting what Stone meant by the footnote indicates the grave difficulties that attend the whole subject, but it can be suggested that Stone's appeal to the 'definiteness' of the Bill of Rights indicates his desire to avoid judicial legislation on the constitutional level, even in the civil liberties area").

324. See ELY, supra note 34; see also COMMAGER, supra note 48, at 67 (noting that the logic behind the distinction made in the Carolene Products footnote between types of laws that "restrict those political processes which can ordinarily be expected to bring about repeal of undesirable legislation" and those that do not is obvious enough); $i d$. ("[A] law that changes the electorate or that denies it access to proper information cannot be reviewed by the same electorate. Legislation therefore that in any way affects the quantity or quality of the body politic is in a peculiar position and must be subject to peculiar scrutiny."). 
and judicial discretion. ${ }^{325}$ It is fair to say that the "process" argument was the one most commonly offered to justify the work of a more liberal, activist Court, that the argument was frequently offered, and was rarely rebutted. ${ }^{326}$ "The freedom of the legislature to act within wide limits of constitutional construction is the wise rule of judicial policy only if the processes through which they act are reasonably democratic," explained Rostow, discussing Stone's footnote. ${ }^{327}$ Freedom of expression required protection because it is "a necessary corollary of representative

325. See, e.g., KAUPER, supra note 159, at $51-52$ ("The preferred position of the First Amendment freedoms and the correlative subordination of economic liberty have been dictated by the Court's conception of a democratic society operating under the aegis of the Constitution. The play of economic forces and the resolution of conflicts between competing economic groups is a matter for determination by the democratic process expressing itself in the legislative voice. The voice of the welfare state has become too persistent and the role of the legislature in promoting economic security too well rooted in popular thinking to be stifled by judicial prepossessions that once flourished in the salubrious climate of a laissez-faire ideology. But by contrast, freedom of expression ... goes to the heart of the democratic process."); SAMUEL J. KONEFSKY, CHIEF JuSTICE STONE AND THE SUPREME COURT 196 (1945) (stating that Stone's words in Carolene "were hardly calculated to commit the Court to an undeviating course of action. Still, they suggest a way out, should the Court feel called upon to explain [its seeming double standard]"); MASON, supra note 301, at 177-78 ("Majorities-and this is a key point in democratic theory-are in flux. Tomorrow's majority may have a different composition as well as different goals. Defense of the political rights of minorities thus becomes, not the antithesis of majority rule, but its very foundation. The majority must leave open the political channels by which it can be replaced when no longer able to command popular support."); see also Forbath, supra note 322, at 179-80 (discussing New Dealers in Congress supportive of this role for the Court). There were critics, such as a young Elliot Richardson, who argued that searching review was inappropriate even in First Amendment cases. But Richardson's arguments against "process theory" sounded more like raw assertion. Richardson, supra note 90 , at 48.

326. See sources cited supra note 325; infra note 329. Most ironic was the debate in Gobitis between Justice Frankfurter and Justice Stone. In upholding the flag salute, Frankfurter argued:

Except where the transgression of constitutional liberty is too plain for argument, personal freedom is best maintained-so long as the remedial channels of the democratic process remain open and unobstructed - when it is ingrained in a people's habits and not enforced against popular policy by the coercion of adjudicated law.

Minersville Sch. Dist. v. Gobitis, 310 U.S. 586, 599 (1940) (footnote omitted). Stone responded:

I am not persuaded that we should refrain from passing upon the legislative judgment "as long as the remedial channels of the democratic process remain open and unobstructed." This seems to me no less than the surrender of the constitutional protection of the liberty of small minorities to the popular will.

Id. at 605-06 (Stone, J., dissenting). For an explanation of the split between Stone and Frankfurter in the Gobitis case, see MASON, supra note 301, at 164 ("The divergence between Stone and Frankfurter indicates disagreement as to the kind of government the framers established and the relation of the Courts thereto."); and id. at 165-66 ("[In 1943, three of the Justices] who had joined the majority [in the flag salute decision] changed their minds. Two new appointees ... endorsed Stone's dissent, thus transforming what was formerly a vote of eight to one in favor of the flag salute into a vote of six to three against it. Speaking for the Court in this remarkable about-face, Justice Jackson built on Stone's dissent in Jones v. Opelika and on the Carolene Products footnote." (footnotes omitted)).

327. ROSTOw, supra note 298, at 160; see also id. ("[S]tatutes which affected interests beyond political protection, or which limited the full democratic potentialities of political action, were not to be approached by the Court with the deference it usually accorded legislative decisions ...."). 
government." 328 Process theorists were taken with the notion that aggressive judicial review was appropriate if its goal was to further the very democratic principles with which judicial review interfered. ${ }^{329}$

Yet even those like Rostow, content with process theory, were obsessed with the countermajoritarian problem. Indeed, Rostow's major work was a defense of judicial review against the countermajoritarian criticism. ${ }^{330}$ Thus, the following odd state of affairs existed. The public approved of, or at least accepted, many of the decisions decried by commentators and dissenting judges. Those same judges and commentators, however, expressed sympathy for the results the Court reached. They claimed to be motivated by a concern for a lack of standards to guide judges and cabin their discretion. Yet there was at least a theory-congenial to many-that seemed to offer some solution to that problem. One might reasonably suppose that something else was motivating the persistent anxiety of midcentury academics about the judicial role, and their concomitant fixation on the countermajoritarian problem.

\section{B. The Law of the Fathers}

As a starting point, an answer presents itself in the peculiar politics of the legal academy at mid-century. The countermajoritarian criticism was advanced aggressively during the Populist-Progressive Era by figures who, by mid-century, had achieved near-iconic status in the legal academy. The Court's critics at mid-century-the "self-appointed scholastic mandarins" 331 - were deeply enmeshed in the tradition of which these iconic figures were a part. And, as part of a not-so-subtle struggle going on between two competing schools of thought-the "realists" of Yale and the Legal Process scholars at Harvard and elsewhere-many of the Court's critics were engaged in an active effort to determine whose views would triumph in the law.

The Legal Process school endeavored to define a role for the judiciary that set it apart from politics. ${ }^{332}$ Some confusion in names is inevitable here,

328. Freund, supra note 90 , at 549

329. See, e.g., CURTIS, supra note 48 , at $327-28$ ("Where the democratic process is not working and the statute is not its result, the Court is free to make up its own mind without the exercise of any self restraint."); id. at 328 ("[W] Court should exercise less than no restraint."); Freund, supra note 90, at 550 ("If . . the court stands one step removed from the clash and compromise of contending interests, its function is basically to keep that process clear and clean.").

330. See infra notes $465-467$ and accompanying text.

331. Wright, supra note 276 , at 777 . Special thanks to Michael Seidman for emphasizing the importance of this part of the argument.

332. For more on the Legal Process school, see generally DUXBURY, supra note 190, at 251 66; HORWITZ, supra note 212, at 247-68; KALMAN, supra note 2, at 19-20; and William N. Eskridge, Jr. \& Phillip P. Frickey, An Historical and Critical Introduction to HENRY M. HART, JR. 
because the Legal Process scholars also offered the primary competition to Justice Stone's Carolene Products solution and the "process theory" it suggested. Legal Process scholars sought to tame realism, but recognized the impossibility of doing so by rendering substantive law determinate. ${ }^{333}$ Their alternative was to establish a set of principles regarding the process of how law was made.

What matters for present purposes is not so much the philosophy of the Legal Process school, which - as we shall see in the next Section-was deeply flawed as a solution to whatever theoretical problem judicial review posed at mid-century. Rather, what is significant for now is the intellectual hegemony perpetuated by these scholars' teachers, and then in turn by the Legal Process scholars themselves. The heroes of the Legal Process school were their teachers and ancestors-especially Hand and Frankfurter-who had cut their teeth criticizing the Court during the Progressive Era. ${ }^{334}$ It is no wonder, then, that mid-century scholars picked up the rhetoric of their teachers in explaining their difficulty with the Supreme Court. ${ }^{335}$

The essential point is that these Progressive Era critics, Frankfurter and Hand, were icons of the legal establishment, and so too their heroes, Holmes and Thayer, the prophets of the Progressive Era struggle. Frankfurter would describe Thayer as the person "who through his writings has influenced me most as to public law." 336 It was, to Frankfurter, "“one of the tragedies of my life' ... 'that [he] was gone by the time I entered Law School." ${ }^{\text {,337 }}$ Frankfurter's relationship to Holmes was of huge importance

\& Albert M. SaCks, The Legal Process, at li, lii-cxxxvi (1994). For a discussion of the relationship between the legal process school and realism, see FELDMAN, supra note 288, at 120 ("The legal process principle of institutional settlement developed the realists' institutional critique of laissez-faire constitutionalism: according to the realists (following Holmes), the Lochner Court had been guilty of judicial activism because it had intruded into the institutional role of the legislature."); and SEBOK, supra note 62, at 115 ("I have begun this chapter on the legal process school with an examination of this short essay by Hart because it portrays in a concise way how the legal process school developed in reaction to (and out of) the success of legal realism ....").

333. Friedman, supra note 188 , at 517 .

334. See EdWARd A. Purcell, JR., Brandeis and the Progressive Constitution: ErIE, THE JUdicial POWER, AND THE POLITICS OF THE FEDERAL COLRTS IN TWENTIETH-CENTURY AMERICA 13 (2000) (describing the involvement of young Felix Frankfurter and Leamed Hand with the Progressive movement).

335. Tushnet \& Lynch, supra note 286, at 471 ("Many educators believe that intellectual 'formations' are relatively firmly set in the earliest years of education, and that appears to be true of approaches people have to questions of legal analysis." (citations omitted)).

336. HiRSCH, supra note 278, at 128 (quoting a February 19, 1944, letter from Felix Frankfurter to Charles Wyzanski); see also Edward A. Purcell, Jr., Learned Hand: The Iurisprudential Trajectory of an Old Progressive, 43 BUFF. L. REV. 873, 885 (1995) (explaining that Holmes, Theodore Roosevelt, Brandeis, and Frankfurter were among those who "claimed allegiance to [Thayer's] views").

337. HIRSCH, supra note 278, at 128 (quoting an October 21, 1940, letter from Frankfurter to Learned Hand). Frankfurter called Thayer's Origin and Scope of the American Doctrine of Constitutional Law "the great guide for judges and therefore, the great guide for understanding by 
to him. ${ }^{338}$ Both Hand and Frankfurter revered Holmes as an icon of a certain legal and academic culture. ${ }^{339}$

It would be difficult to overstate the status of these individuals in the legal academy at mid-century. Thayer's work was deemed seminal. ${ }^{340}$ In his careful attack on the countermajoritarian notion, Black began his discussion of Thayer by explaining, "[I]n selecting his article for discussion ... I am going to the source of a river that flows right by the door of today.",341 Frankfurter and Hand were equally important. "Throughout the nineteenforties and even fifties, the judicial philosophies of Felix Frankfurter and Learned Hand held center stage. "342

And so it was that leading academics viewed this line-from Thayer to Holmes to Hand to Frankfurter - as the tradition within which they had no choice but to work. ${ }^{343}$ In delivering the Cooley Lectures at the University of Michigan in 1969, Philip Kurland would happily identify himself as "one of those antediluvians from the University of Chicago who purportedly live entirely on the intellectual sustenance of Felix Frankfurter and Adam

non-judges of what the place of the judiciary is in relation to constitutional questions." Sanford Victor Levinson, Skepticism, Democracy, and Judicial Restraint: An Essay on the Thought of Oliver Wendell Holmes and Felix Frankfurter 217 (1969) (unpublished Ph.D. dissertation, Harvard University) (on file with author) (quoting FELIX FRANKFURTER, FELIX FraNKFURTER REMINISCES 347 (1960)).

338. See HIRSCH, supra note 278, at 31 (describing Frankfurter's relationship with Holmes as "highly significant emotionally for Frankfurter"); see also Dennis J. Hutchinson, Felix Frankfurter and the Business of the Supreme Court, October Term 1946-October Term 1961, 1980 SUP. CT. REV. 143, 205 ("'We would have been inclined to agree with Felix more often in conference,' Justice William Brennan said, 'if he quoted Holmes less frequently to us."').

339. See GuNTHER, supra note 186, at 345 ("For Hand, Holmes was an unblemished idol on the bench ...."); HIRSCH, supra note 278, at 32 ("Throughout his life Frankfurter's friendship with Holmes was his most cherished possession. It was Holmes who symbolized to Frankfurter the best of everything: the Brahmin establishment, achievement in the law, culture, learning.").

340. See CAHILL, supra note 159, at 64-65 (discussing Thayer's "famous" "Rule of Administration"). A Northwestern University Law Review symposium described the significance of Thayer's work on legal academics and judges:

James Bradley Thayer's The Origin and Scope of the American Doctrine of Constitutional Law was the first systematic defense of what has come to be known as rationality review-the duty of a reviewing court to defer to the judgment of the politically accountable branches of government unless the legislation under review is so obviously contrary to the Constitution as to leave no room for reasonable doubt. This idea was an acknowledged major influence on Justices Holmes, Brandeis, and Frankfurter, who utilized it to defend reform legislation against constitutional objections, and it continues to frame judicial debate today.

Symposium, One Hundred Years of Judicial Review: The Thayer Centennial Symposium, 88 Nw. U. L. REV. i, v (1993) (citation omitted). The same symposium quotes Henry P. Monaghan, Marbury and the Administrative State, 83 COLUM. L. REV. 1, 7 (1983) (calling Thayer's essay "the most influential essay ever written on American constitutional law").

341. BLACK, supra note 1, at 193.

342. SHAPIRO, supra note 65 , at vii.

343. Notably, things on the Court were not that different. See MELVIN I. UrofSKY, FELIX FRANKFURTER: JUDICIAL RESTRAINT AND INDIVIDUAL LIBERTIES 32 (1991) ("If at times in this volume it appears that one should refer to a 'Frankfurter Court,' that is not an inapt expression. Frankfurter's ideas, even when he did not prevail, formed the basis of discussion."). 
Smith." 344 The Legal Process school "treated Frankfurter as the symbol of judicial restraint and the integrity of the legal process."," "Felix Frankfurter's influence was felt at Harvard," explains William Wiecek, "long after he left for Washington. ${ }^{346}$ The names Holmes, Frankfurter, Hand (Frankfurter), Thayer (still more Frankfurter) fairly leap off the pages of The Least Dangerous Branch. ${ }^{347}$ Bickel, of course, was a follower of sorts of the restraintists, but the same devotion to these iconic figures was true of Dean Rostow's work, even though Rostow was on a very different side of things ${ }^{348}$ Martin Shapiro, hardly a sycophant of the Legal Process school, would explain in the preface to his path-breaking Law and Politics in the Supreme Court: "The one truly moving episode of my graduate education was hearing Learned Hand deliver the Holmes Lectures, and my thinking about the Supreme Court has been largely an attempt to grapple with the ideas of Hand, Justice Frankfurter, and Professor Wechsler." 349

This disagreement between two schools of thought-Legal Process and process theory-also was a struggle between two of the nation's leading legal institutions: Yale and Harvard. Legal Process and judicial restraint was Harvard's chief position, while Yale represented Realism, compatible with the activism of the Warren Court. Yale law professor Charles Black, in the preface to his book sweeping away the countermajoritarian difficulty, acknowledges a "special debt to [Yale] Dean Eugene V. Rostow, who has pioneered in the work of restoring the institution of judicial review to its traditional place, in challenge to the views academically fashionable in the generation now summing its count. ${ }^{, 350}$ Rostow, in his own introduction,

344. KURLAND, supra note 175 , at xi.

345. KALMAN, supra note 2, at 30; see also Charles M. Lamb, Judicial Restraint on the Supreme Court, in SUPREME COURT ACTIVISM AND RESTRAINT 7, 9 (Stephen C. Halpern \& Charles M. Lamb eds., 1982) ("To begin to understand judicial restraint, one is most likely to turn to the opinions of either Justice Oliver Wendell Holmes or Justice Felix Frankfurter.... Frankfurter should be used as a prototype of restraint since ... Frankfurter more closely abided by this doctrine than did other great restrainters-Holmes, Louis D. Brandeis, and Harlan F. Stone.").

346. William Wiecek, Jurisprudence After the War 10 (Mar. 8, 2002) (unpublished manuscript, on file with author) ("Peter Edelman claims, with only a little exaggeration, that 'at the Harvard Law School ... in the late 1950s, Felix Frankfurter was God." (quoting Peter B. Edelman, Justice Scalia's Jurisprudence of the Good Society: Shades of Felix Frankfurter and the Harvard Hit Parade of the 1950s, 12 CARDOzo L. REv. 1799 (1991))); id. ("'Our Felix,' as he was supposedly called, was for them [at Harvard] the 'shining light of Western jurisprudence."” (quoting L.A. Powe, Jr., Justice Douglas After Fifty Years: The First Amendment, McCarthyism and Rights, 6 CONST. COMM. 267, 278 (1989))).

347. See BICKEL, supra note 16, at 2, 16, 26, 33, 35, 80, 108, 109, 151, 199, 238 (mentioning Holmes); id. at 15, 35, 40, 55, 85, 94, 115, 116, 131, 146, 154, 194, 210, 211, 236, 238, 239, 240 (mentioning Frankfurter); id. at 2, 20, 23, 24, 46, 47, 48, 49, 69, 239 (mentioning Hand); id. at 2 , $21,22,23,35,36,39,40,42,43,44,45,46,235$ (mentioning Thayer).

348. See, e.g., RosTow, supra note 298, at xvi, 121, 151, 184 (mentioning Frankfurter); id. at xvi, $118,128,130,131,132,133,134,135,161,163,164,165,166,183$ (mentioning Hand); id. at $156,157,158,159$ (mentioning Thayer).

349. SHAPIRO, supra note 65 , at vii.

350. BLACK, supra note 1 , at vii. 
describes the tension between Realism-whose "ancestors are Montesquieu, Ehrlick, Pound, Holmes, and Cardozo"-and the "legal positivism" of some "like Judge Learned Hand and Mr. Justice Frankfurter." The former tradition "has represented the prevailing approach to legal studies at the Yale Law School to a greater extent than has been the case in any other law faculty of the world." 351 On the other hand, historian Lucas Powe calls Legal Process "the Harvard jurisprudence."352 Frankfurter - as devoted a son of Harvard as there was ${ }^{353}$-disdained the attitude at Yale. He decried the "narrow minded prejudices of Earl \& Black \& Douglas" and their desire to have "the avant garde of the Yale Law School and Edmond Cahn's praise them." "354 The editors of the Harvard Law Review, Laura Kalman pointed out, were well aware of this Harvard tradition, and while applauding it in some respects, nonetheless expressed concern that there "seemed to be too much emphasis on durability and not enough on development." 355 The fight spilled out into the popular press. ${ }^{356}$ One charming example was a 1966 article by Victor Navasky in the New York Times Magazine called The Yales v. The Harvards (Legal Division). Although somewhat biased toward Yale (from which Navasky graduated), the article captured quite nicely the competing traditions of Legal Realism (Yale) and legal craft (Harvard).

Those who took sides in this dispute worked actively to perpetuate the tradition in which they situated their ideas. The process of tradition-making was more organic than simple recognition of the importance of a Hand or Holmes would suggest. ${ }^{357}$ Frankfurter was legendary in this regard, of

351. Rostow, supra note 298 , at $\mathrm{xv}$.

352. Powe, supra note 346 , at 278.

353. See HIRSCH, supra note 278 , at 19, 20; see also FELIX FRANKFURTER ON THE SUPREME COURT: EXTRAJUDICIAL ESSAYS ON THE COURT AND THE CONSTITUTION, at viii (Philip B. Kurland ed., 1970) (referring to the book's publication by the Harvard University Press, the editor indicates, "I regret only that the Justice did not survive to see the volume brought to fruition under the imprint of the University which was so important to him and to which he was so important").

354. HIRSCH, supra note 278, at 181.

355. KALMAN, supra note 2, at 51 ; see also id. (noting that the editors of the Harvard Law Review criticized the "form process theory had taken. 'Emphasis on principled, restrained adjudication is commonly associated with a great tradition of scholars and judges often connected in some way with the Harvard Law School,' they observed, noting that Frankfurter, Hart, and Bickel, among others, had all studied law at Harvard and served on its law review."); id. at 30 (identifying Legal Process scholars and their ties to other schools).

356. See The Case for Yale Law School, NEWSWEEK, June 10, 1963, at 100, 103 (discussing the Legal Realist tradition at Yale); Victor Navasky, The Yales v. The Harvards (Legal Division), N.Y. TIMES, Sept. 11, 1966, $\$ 6$ (Magazine), at 47; Schlesinger, supra note 82.

357. It was also not necessarily faithful to the ideas that were being transmuted. Thus, Edward Purcell explains how the version of judicial deference advanced by his "progressive apostles" differed significantly from Thayer's, in that, inter alia, Thayer would not have applied the same rule to the review of state legislation by the Supreme Court. Purcell, supra note 336, at 886-88, 893-94. Similarly,

Frankfurter was a self-acknowledged disciple of Holmes, but he also transmuted his thought in such a way that it has become accepted by a wide portion of the legal 
course. ${ }^{358}$ Tradition perpetuation came from a sense of self-importance, and a desire to further that importance. As Stephen Feldman explains, "[T]he legal process scholars firmly believed that they themselves were important actors in the legal system. They were convinced that they should instruct Supreme Court Justices about the law, that the Justices would listen, and that the Court's decisions (and hence the scholars' instructions) changed American society." 359

In the process of cementing their own place in the pantheon of law, if not society, the Legal Process camp had an enemy to work against in the form of Earl Warren and the Warren Court. "Studying the biographies of the liberal justices," Morton Horwitz observes, "one is immediately struck by the extent to which they were themselves outsiders. $" 360$ Warren himself seemed to have little respect for the traditional norms of the law: "[I]t was common" at Harvard Law School, in the 1960s, Horwitz reports, "to mock Warren for often asking from the bench whether a particular legal position was 'just.' Sophisticated legal scholars did not speak that way." ${ }^{, 361}$ On the Court, Frankfurter "attacked the 'Axis"” (referring to Douglas, Black, and Murphy) "for their failure to follow his lead and adhere to strict standards of judicial decision making." 362

That reputations were at stake as well as legal theory was evident from the thinly veiled contempt that found its way into academic commentary on the craft of the Warren Court. In private correspondence the depth of feeling was extraordinary. G. Edward White reports Hand (in correspondence with Frankfurter) calling Warren "that Dumb Swede."363

fraternity (particularly those trained at Harvard) and the public as the uniquely valid version of the meaning of constitutionalism in America.

Levinson, supra note 337, at 6 . Holmes's "defense of judicial restraint" was based on "the simple recognition of sheer power" not the "premises of democracy" advanced by Frankfurter. Id. at 12930 .

358. "A justice may be well connected to communities that help shape the image of justices and may thus be ascribed a stature, even a reverence, that colleagues on the Court did not ascribe to him or her: the leading example here is Justice Felix Frankfurter." White, supra note 144, at 38. Frankfurter had a boundless energy for correspondence, and famously promoted the students of whom he felt most proud, but part of their job was keeping the faith. He has been described as the "self-proclaimed inheritor of the mantle of self-restraint from Holmes and Brandeis." UROFSKY, supra note 343 , at 65 .

359. FELDMAN, supra note 288, at 122.

360. HORWTT, supra note 133 , at 13.

361. KALMAN, supra note 2, at 46-47 (quoting Morton Horwitz, The Warren Court and the Pursuit of Justice, 50 WASH. \& LEE L. REV. 5, 11 (1993)).

362. UROFSKY, supra note 343 , at 65 . He also did so off the Court. See GUNTHER, supra note 186, at 665 (noting that in Frankfurter's correspondence with Hand "the Warren Court's performance evoked comments as bitter and sarcastic as those he had directed at the product of the Nine Old Men in the 1930s").

363. White, supra note 144, at 180; see also UROFSKY, supra note 343, at 45 ("As soon as they convince the people that they can do what they want, the people will demand of them that they do what the people want. I wonder whether in times of blind reaction-[and] they are coming-Hillbilly Hugo, Good Old Bill, and Jesus lover of my Soul [Murphy] will like that."). 
But what found its way into print was often almost as bad. ${ }^{364}$ Henry Hart observed that "first-rate lawyers" would scoff at the Warren Court, evoking an equally vituperative response from Thurman Arnold who described such lawyers as "running dogs of the corporations." ${ }^{365}$ Perhaps the most famous was a broadside by Philip Kurland who, in commenting upon the quality of Warren Court decisions, likened the Justices to bad piano players sorely in need of lessons. ${ }^{366}$

As the fight between these schools of thought deepened-fought always in terms of the countermajoritarian problem-it became quite explicitly a battle for the souls of esteemed historical figures. One example of this was the struggle over Brandeis. Brandeis himself had been a Progressive, and had authored perhaps the most famous Supreme Court opinion establishing the notion of restraint in constitutional cases. ${ }^{367}$ At the same time, however, he also displayed great sensitivity to concerns about civil liberty ${ }^{368}$ No surprise, then, that adherents on both sides sought to claim him. ${ }^{369}$ Similarly caught up in the struggle was Holmes, generally

364. For example, in one article, Bickel and Harry Wellington stated:

The Court's product has shown an increasing incidence of the sweeping dogmatic statement, of the formulation of results accompanied by little or no effort to support them in reason, in sum, of opinions that do not opine and of per curiam orders that quite frankly fail to build the bridge between the authorities they cite and the results they decree.

Alexander Bickel \& Harry H. Wellington, Legislative Purpose and the Judicial Process: The Lincoln Mills Case, 71 HARV. L. REV. 1, 3 (1957).

365. Thurman Arnold, Professor Hart's Theology, 73 HARV. L. REV. 1298, 1315 (1960) ("I do not know what 'first-rate lawyers' Professor Hart has in mind. But to the public, first-rate lawyers can only mean men with large corporate practices and leaders in the American Bar Association who are now attacking the Court."); Hart, supra note 43, at 101 (noting that, with respect to poorly drafted Warren Court opinions, "[i]t needs to be said with all possible gravity, because it is a grave thing to say, that these failures are threatening to undermine the professional respect of first-rate lawyers for the incumbent Justices of the Court").

366. Kurland wrote:

It behooves any critic of the Court's performance to close on a note reminiscent of the wall plaque of frontier times: "Don't shoot the piano player. He's doing his best." It is still possible, however, to wish that he would stick to the piano and not try to be a oneman band. It is too much to ask that he take piano lessons.

Kurland, supra note 49 , at 176.

367. Ashwander v. Tenn. Valley Auth., 297 U.S. 288, 341 (1936) (Brandeis, J., concurring).

368. See, e.g., ROBERT A. BURT, Two JEWISH JUSTICES: OUTCASTS IN THE PROMISED LAND 26-27 (1988) ("Though Brandeis and Holmes usually dissented together from the Court majority's regular invocation of 'liberty' to overtum state laws, this time [Meyer v. Nebraska, 262 U.S. 390 (1923)] Brandeis joined the Court's opinion while Holmes dissented.").

369. See, e.g., BICKEL, supra note 265, at 116; BURT, supra note 368, at 21 (noting the "possibility that Brandeis did not truly qualify for membership in the Harvard school. To adapt Dean Acheson's observation, those who knew him best embraced him least."); id. at 23 (observing that Brandeis's invocation of "the conventional doctrinal formula [in Jay Burns Baking Company v. Bryan, 254 U.S. 504 (1924)] . . makes it easy to misread him as a matriculant of the Harvard school. But his true purpose, as well as the premise that ordinarily led him to defer to legislative enactments, was more accurately ... that the judicial function, as he saw it, was "to determine ... whether the measure ... transcends the bounds of reason' as fair-minded, tolerant men (as he saw them) would define reason."); HIRSCH, supra note 278, at 158 (quoting 
deemed a patron saint of judicial restraint, yet note how Rostow cited him in the list of Realists. ${ }^{370}$ Indeed, the case of Holmes and Brandeis posed special problems for Frankfurter, for he admired both men and sought to place himself in their stead. Thus, he struggled when their prior decisions pointed in opposite directions. ${ }^{371}$ In a paean to Holmes, written in 1938, Frankfurter found the double standard to be no problem at all: "Naturally, therefore, Mr. Justice Holmes attributed very different legal significance to those liberties of the individual which history has attested as the indispensable conditions of a free society from that which he attached to liberties which derived merely from shifting economic arrangements."372 Frankfurter declined in his own judicial career, however, to draw such a line between economic and civil liberties legislation. Thus, late in his career, eager to justify his own work, he simply had to confront how far he might have strayed from the Justice he so admired. "The more I write on this subject," Frankfurter wrote Mark DeWolfe Howe, "the more I realize I am depicting a real wart on my hero.",373

Perhaps the most bizarre example of this effort to wedge admired historical figures into the appropriate academic and theoretical mold was

Frankfurter as noting in his personal papers that "[a]ccording to my custom in sending Brandeis all my draft opinions after he retired-circulating to him as to the sitting Justices-I sent this [opinion] to him when shortly thereafter, I saw him he said 'That's a very fine opinion of yours. I assume that you have a unanimous Court.' 'Certainly not' I replied and told him that I may not have even a majority and that Black was writing. To which he said 'Black and Co. are going mad."'); Louis L. Jaffe, Was Brandeis an Activist? The Search for Intermediate Premises, 80 HARV. L. REV. 986 (1967); see also PURCELL, supra note 334, at 227 ("[B]y the end of the 1950s the new and carefully constructed image of 'Brandeis of $A$ shwander' bore a much closer resemblance to Frankfurter than it did to its ostensible subject.").

370. See Rosrow, supra note 298; supra text accompanying note 351. Levinson describes this fight over Holmes, comparing Frankfurter's characterization of him as a restraintist, and Rostow's and Jerome Frank's use of him to further the creative image of judging favored by Yale. See Levinson, supra note 337, at 106. Cahill attempts to explain Holmes's deviations from restraint:

[I]n one class of cases only does Holmes apparently depart from the view that the majority will must prevail. In the area of civil rights ... he seems particularly alert to the dangers of governmental power. And yet one cannot be certain that the deviation is not more apparent than real. In general, law was to him a method by which the dominant power achieved its desires, and he was willing to resolve every doubt in favor of the majority's action. It is entirely possible that in these cases again he was concerned principally with method, in these cases with the method by which majorities could come into being, and only secondarily with results.

CAHILL, supra note 159 , at 43.

371. See HIRSCH, supra note 278, at 133 (describing Frankfurter's difficulty in civil liberties decisions: "His guides on these matters, as on all others, were Holmes and Brandeis. But here again, the two disagreed."); see also MASON, supra note 320, at 141-42 (quoting Holmes's 1930 comment: "I told him [Brandeis] long ago that he really was an advocate rather than a judge. He is affected by his interest in a cause, and if he feels it he is not detached." (quoting ALEXANDER BICKEL, THE UNPUBLISHED OPINIONS OF MR. JUSTICE BRANDEIS 222 (1957))).

372. FeliX FrANKFURTER, MR. JUSTICE HOlMES AND THE SUPREME COURT 51 (1938).

373. HIRSCH, supra note 278, at 200. 
Hand's own eulogy for Justice Stone in the Columbia Law Review. ${ }^{374}$ Stone, of course, was the author of the Carolene Products footnote, and arguably turned the corner on the double standard at a time when many of his contemporaries could not. Without devoting too much attention to this point, Wechsler's own contribution to the memoriam made clear the significance of Stone's concern for civil liberties. ${ }^{375}$ For Hand, however, Carolene Products and cases that relied upon it seemed not to have happened at all. After rehearsing the importance of democracy as a decisional basis, and describing the double standard, Hand had this to say about Stone: "He could not understand how the principle which he had all along supported, could mean that, when concerned with interests other than property, the courts should have a wider latitude for enforcing their own predilections, than when they were concerned with property itself." ${ }^{376}$ Hand continued, almost incredibly, "There might be logical defects in his canon, but it deserved a consistent application or it deserved none at all. . . It was because he was throughout true to this view, that, it seems to me, we should especially remember him with gratitude, and honor him as a judge."

It took a real commitment to one's side to be so aggressively blind to reality in describing the author of the Carolene Products opinion. ${ }^{378}$ As Morton Horwitz has observed, "Hand's effort to enlist Chief Justice Stone's reputation against a preferred position stance seems astonishing in its failure to acknowledge Stone's important contributions to actually shaping such a position." But such commitment was manifest in commentary on the Warren Court. Articles, books, and speeches that attacked the Court relied heavily upon the arguments of these adored figures of the Progressive Era and the legal profession. ${ }^{379}$ Their status was such that they set the terms of the debate even for advocates of a more activist judiciary. ${ }^{380}$ Those such as Eugene Rostow, who thought little of the countermajoritarian problem, still felt compelled to respond to Frankfurter and particularly to Hand. ${ }^{381}$ Thus were the terms of the debate determined by these iconic figures of the law.

374. Learned Hand, Chief Justice Stone's Conception of the Judicial Function, 46 COLUM. L. REV. 696 (1946); see also Purcell, supra note 336, at 917-18 (observing that Hand's discussion of Stone's views "distorted them shockingly").

375. See Wechsler, supra note 118, at 793-800.

376. Hand, supra note 374 , at 698 .

377. Id. at 698-99.

378. HORWITZ, supra note 133, at 264.

379. See supra Section IV.B.

380. See supra Section IV.B.

381. Rostow, supra note 129, at 200-04 (responding to the arguments of Hand and discussing the role of Thayer); see also Rostow, supra note 187, at 583-84 (responding to Hand's countermajoritarian concerns). 


\section{The Liberals' Dilemma}

The fixation with the countermajoritarian problem at mid-century rested deeply in this scholarly tradition. However, it was more than just that. After all, the Legal Process scholars and their contemporaries lived in another time and place from their teachers, and had to come to grips with what uniquely confronted them.

Ultimately the scholarly fixation with the countermajoritarian problem revealed itself in an inability to solve a tension that history had bestowed upon them. This was the tension between the traditional progressive challenge to judicial review on democratic grounds and approval of the Warren Court's actual decisions. Those who approved of the Warren Court reform efforts, but nonetheless claimed fidelity to the democratic creed of their Progressive Era predecessors, had in their minds an inescapable dilemma. And if this dilemma itself was more apparent than real-after all, we have seen that the countermajoritarian critique of the Warren Court did not necessarily make sense, and that the Carolene Products rationale justified many of the favored decisions - then perhaps the ultimate problem was that some academics had come to believe in an institution like the Court, but in light of the battles of an earlier era, necessarily feared for its survival if it took an activist course.

\section{The Double Standard}

Here again, the problem came down to the Court's change in direction after 1937, and the inability of some to make the switch with it. When the Court switched sides after 1937, so did its audience, critics and proponents alike. Anthony Lewis would quote a prominent virulent critic of the Warren Court as saying:

Traditionally, the spirit of America has been that if you do not like the rules of the game, change the rules-but don't soak the umpire.

For generations the Supreme Court of the United States has been the umpire....

To say that this tribunal of nine men shall not henceforth declare the supreme law of the land is to say in effect that we must change our form of government and substitute the rule of passion for the rule of reason. 
Of course, as Lewis pointed out, that critic "made the comment in 1937 in a book dedicated to "nine honest men." 382 His views had changed substantially in the interim. As another commentator observed, "[O]ne is struck by the irony that liberals and conservatives have today adopted views completely the reverse of those each held in the constitutional crisis of the 1930s." 383

The switch was easy enough for conservative critics of the results of the Warren Court decisions. After all, conservatives had always believed (or at least since it started to matter in the 1800s) that the Constitution, as interpreted by the Supreme Court, properly tempered the will of the mob. For the most part, they simply could attack the Supreme Court's decisions on the merits, not having to confront any particular tension with their earlier views about judicial review. In other words, without attacking the institution, they could still argue that its decisions were wrong as a matter of constitutional law. ${ }^{384}$

But for academic liberals - those who approved the results of the Court's decisions-the switch posed a deeper intellectual problem. Inevitably, judges "had to explain their acceptance of an essentially unlimited government in the economic domain, yet also ... to allow them to enforce limits on government in the domain of civil rights and civil liberties." 385 For some this was exceedingly difficult. "Throughout the

382. Lewis, supra note 188 , at 311 (quoting DAVID LAWRENCE, SUPRFME COURT OR POLITICAL PUPPETS 1 (1937)); see also KURLAND, supra note 175, at xiii-xiv (showing a similar juxtaposition with Coolidge and New Republic quotes from 1924 and 1926 respectively).

383. White, supra note 144, at 196; see also Jenner-Butler Hearings, supra note 178, at 47 (statement of Joseph L. Rauh, National Director, Americans for Democratic Action) ("It is unusual to find an organization of liberals acting as one of the most outspoken defenders of the Court. History shows that it has always ... been the conservative interest in America who have defended the Supreme Court against liberal attack. We have had ... a 180-degree switch since the [Court-packing plan] in which the liberals in America... were supporting the plan, and the conservative interests were opposed to the plan. And today I would say that the reversal of that situation is somewhat strange."); Bickel \& Wellington, supra note 364, at 2 ("[T]he word conservative does effectively evoke a type of politician and commentator arrayed in defense of the Supreme Court twenty years ago and now in full cry against it."); Rodell, Warren Court Stands Its Ground, supra note 197, at 120 ("Accusations of too-much-Court-power have also reversed polarity.... In the [1930s] it was the liberals who cursed the Court for killing progressive legislation. ... Today it is, by and large, conservative elements who accuse the Court of usurping power and upsetting the Federal balance...."); Alan F. Westin, When the Public Judges the Court, N.Y. TIMES, May 31, 1959, $\S 6$ (Magazine), at 16 ("Previously, it was the spokesmen for liberalism and majority rule ... who denounced the Supreme Court. ... Yet in the [1950s], liberal groups are defending the judiciary as a wise agency... . A similar reversal has taken place in the conservative camp.").

384. See, e.g., LAWRENCE, supra note 382.

385. Mark Tushnet, Members of the Warren Court in Judicial Biography: Themes in Warren Court Biographies, 70 N.Y.U. L. REV. 748, 750 (1995); see also MCCLOSKEY, supra note 63, at 5 ("The doubts spawned in an era when the Court had intervened on behalf of the economic rights of some necessarily remained to trouble justices who were asked to intervene on behalf of the civil and political rights of others."). As one contemporary commentator said: 
twenties and thirties, Frankfurter had decried the Court's strangulation of liberal social legislation.... Yet in the area of jurisprudence that was in fact to become the main preoccupation of the post-1937 Court-civil liberties and civil rights-Frankfurter was unprepared for what was to come." ${ }^{386}$ For Hand, the problem was so insoluble that he recommended extreme deference to legislative judgments just shy of judicial abdication. "I cannot frame any definition that will explain when the Court will assume the role of a third legislative chamber and when it will limit its authority to keeping Congress and the states within their accredited authority." 387

The switch appeared to occasion a critical split in the liberal ranks. Thus, Felix Frankfurter, firmly in the restraintist camp, would feel compelled to "plead guilty" to the charge of having an "old-fashioned liberal's view of government and law." 388 And Arthur Sutherland, explaining the developing split, would have to define his terms: "I take a 'liberal' to mean the sort of man who enjoyed the New Republic about 1923." ${ }^{389}$ What both these men were saying was that it was difficult to go from being a liberal in the Progressive Era, when Court-bashing had been the thing, to being a liberal at mid-century, when liberals were finding

Since the days when it became customary to speak of the Supreme Court in terms of the "conservative" majority and the "liberal" minority, it has been apparent that the attitude of some of the liberals toward government regulation of business enterprise was somewhat at variance with their approach to civil liberty issues. Indeed, as compared with their willingness to allow legislatures free play in the formulation of economic policy, their attitude toward legislative restrictions on fundamental rights seemed to be, at least at first glance, a contradiction in terms.

KONEFSKY, supra note 325 , at 193.

386. HIRSCH, supra note 278 , at $132-33$.

387. HAND, supra note 122, at 55; see also Landauer, supra note 278, at 235 (noting that "Hand was not fully comfortable with the political implications of his argument in 1958. It should, however, have been obvious to all that the 'Old Chief' was fighting an old battle, inveighing against the evils of the activism of the Lochner-era Court"). Hand stood virtually alone in his skepticism about the legitimacy of judicial review, but hardly in the conclusion that followed. "Several, who disagree with Judge Hand about the legitimacy of judicial review, would so encumber its exercise with rules and principles of exegesis as to accomplish nearly the same end-that of limiting the judicial influence in the formation of the constitution." RosTow, supra note 298 , at xviii (citing the Legal Process scholarship).

388. Felix Frankfurter, John Marshall and the Judicial Function, 69 HARV. L. REV. 217, 237 (1955) (emphasis added).

389. Sutherland, supra note 129 , at 170 . Sutherland put the point sharply by quoting a 1924 article in the New Republic taking President Coolidge to task for protesting the manner of a Senate committee investigation of Treasury Secretary Andrew Mellon. Id. at 173-74. Coolidge complained of the breakdown in the protections of search and seizure, the rules of evidence, and reliance on the grand jury, but the New Republic then defended the invasions on instrumental grounds. This was difficult to explain, Sutherland felt, in light of a subsequent liberal defense of the Court for limiting congressional committees during Communist witch hunts:

Herc again there is no evidence of a gift of foresight. That a day might come when investigations by a Senate committee would suggest that a certain number of public employees and private citizens had entered into a different sort of conspiracy; that in such an event constitutional protection of those accused might appear in a different light....

Id. at 174 . 
much to applaud in the Court's work. The move from critic to apologist was a difficult one.

In practice this split was more apparent than real, because Hand (perhaps) aside, it was not like any of the so-called old-fashioned liberals were really ready to abandon entirely the "constitutional" part of "constitutional democracy." 390 For example, in Sweezy v. New Hampshire, Frankfurter wrote a concurring opinion invalidating a state investigation into the lectures and political affiliation of an academic. ${ }^{391}$ "This is an opinion of first importance, ${ }^{, 392}$ wrote Bickel, complimenting the example of how to give due process substantive content, but explaining nonetheless that "he never successfully identified sources from which this judgment was to be drawn that would securely limit as well as nourish it." ${ }^{.393}$ Similarly, in McCollum, ${ }^{394}$ in which the Court struck down a state release-time program for religious instruction, Frankfurter filed a concurring opinion referring to the Establishment Clause as a "great American principle." Nonetheless, as one Frankfurter biographer has observed, "it violated nearly every assumption upon which his system of judicial belief supposedly rested.,395

So, there was a very real problem for those embedded in the Progressive tradition who still approved the exercise of judicial review. Striking down laws required a theory. If one was going to countenance the exercise of judicial review, it required-or so it seemed to them-a justification for that exercise.

390. See Levinson, supra note 337 , at 283 (explaining how neither of the restraintists, Holmes or Frankfurter, was "willing to commit himself to dispensing with the institution of judicial review entirely, a tenable idea which would follow logically from many of their arguments").

391. In his concurrence, Frankfurter wrote:

For a citizen to be made to forego even a part of so basic a liberty as his political autonomy, the subordinating interest of the State must be compelling. Inquiry pursued in safeguarding a State's security against threatened force and violence cannot be shut off by mere disclaimer.... But the inviolability of privacy belonging to a citizen's political loyalties has so overwhelming an importance to the well-being of our kind of society that it cannot be constitutionally encroached upon on the basis of so meagre a countervailing interest of the State as may be argumentatively found in the remote, shadowy threat to the security of New Hampshire allegedly presented in the origins and contributing elements of the Progressive Party and in petitioner's relations to these.

354 U.S. 234, 265 (1957) (Frankfurter, J., concurring).

392. BICKEL, supra note 265 , at 33 .

393. Id. at 34.

394. MeCollum v. Bd. of Educ., 333 U.S. 203, 231 (1948) (Frankfurter, J., concurring).

395. HIRSCH, supra note 278, at 193; see also RoDELL, supra note 104, at 321 ("Frankfurter, judicial-restrainedly timid and voluminously academic, deplored Congress's cavalier treatment of freedom of speech while simultaneously deploring his own obviously self-imposed inability to do anything about it."). 


\section{Unsuccessful Attempts To Explain the Judicial Role}

The most famous, and most theoretical, of the Legal Process approaches was the argument for "neutral principles." If any debate characterizes the Warren Court era most prominently, it is this debate over the possibility of "neutral principles" of constitutional law. ${ }^{396}$ The foremost proponent of the neutrality argument was Herbert Wechsler. ${ }^{397}$ Disagreeing with Learned Hand's view that the exercise of judicial review was itself an uneasy understanding of the Constitution, Wechsler maintained that in deciding constitutional cases, courts "are bound to function otherwise than as a naked power organ." 398 Rather, they "are obliged to be ... entirely principled. A principled decision... is one that rests on reasons with

396. Compare Cox, supra note 267 , at 98 ("TThe major influence in judicial decisions is not fiat but principles which bind the judges as well as the litigants and apply consistently yesterday, today, and tomorrow."), M.P. Golding, Principled Decision-Making and the Supreme Court, 63 COLUM. L. REV. 35, 40 (1963) ("A decision or judgment is principled only when it is guided by some 'external consideration,' i.e., a guiding principle that contributes to the deliberation on the case. Such a principle is a reason... for the decision."), and Henkin, supra note 185, at 653 ("Neutral principle ... means ... a rule of general application ... [and those] principles which the Court announces must be logically and consistently applied."), with Arthur S. Miller \& Ronald F. Howell, The Myth of Neutrality in Constitutional Adjudication, 27 U. CHI. L. REV. 661, 661 (1960) (suggesting that "neutrality, save on a superficial and elementary level, is a futile quest; that it should be recognized as such; and that it is more useful to search for the values that can be furthered by the judicial process than for allegedly neutral or impersonal principles which operate within that process"), and Eugene V. Rostow, American Legal Realism and the Sense of Profession, 34 ROCKY MTN. L. REV. 123, 124 (1962) ("Law ... must be judged by the results it achieves, not by the niceties of its internal structure; it must be valued by the extent to which it meets its end, not by the beauty of its logical processes or the strictness with which its rules proceed from the dogmas it takes for its foundation."). For an interesting argument that the most fervent of claimed heirs to Wechsler's neutral principles (Bickel, Kurland, Bork) were also the least faithful to Wechsler's original notion, see SEBOK, supra note 62, who wrote:

[T] he conservative critics of Wechsler, saw themselves as the tnie heirs of the theory of reasoned elaboration. Their interpretations of Wechsler and legal process were so different from Hart and Sack's original theory, however, that they should be seen as usurpers of the legal process tradition, and not its heirs .... Through their intervention, the conservative critics succeeded in making original intent-or interpretivism-the ultimate form of legal process.

Id. at 187-95.

397. See FELDMAN, supra note 288, at 127 ("The heated dispute between legal process theorists and the Warren Court finally boiled over in 1958, when Herbert Wechsler issued the ultimate challenge to the Court and its defenders."); SEBOK, supra note 62, at 179-80 ("Wechsler's 1959 Holmes Lecture, entitled Towards Neutral Principles of Constitutional Law ... is probably the most important of the legal process writings, not because it is the best (clearly The Legal Process itself best expresses its own theory) but because it applied reasoned elaboration to the most pressing problem in constitutional law at the time-racial equality under the federal constitution - and, by assuming that challenge, drew the attention of a wide audience of lawyers and nonlawyers. ... In my opinion, the essay prejudiced an entire generation of liberal scholars to the point where few chose to look past Wechsler's presentation of reasoned elaboration before rejecting the project out of hand.").

398. WECHSLER, supra note 190, at 27. 
respect to all the issues in the case, reasons that in their generality and their neutrality transcend any immediate result that is involved.,399

Yet, Wechsler's plea for neutral principles set off a gale of criticism and scorn, in large part because among the decisions he could not justify on principle was Brown. ${ }^{400}$ A fair number of those who responded agreed with him in general terms that principled decisionmaking was required, but believed they could justify Brown on the very sort of principle he envisioned. ${ }^{401}$ However, others ridiculed the very idea of principled decisionmaking. ${ }^{42}$ For these critics, what mattered were principled results. The Warren Court decisions were just, and on this pillar of rectitude they properly rested. Skelly Wright believed the Court's job was to "keep the community true to its own fundamental principles. ... [T] he Warren Court has not simply decreed the right results, but . . . it was right to have decreed them. ${ }^{, 403}$

Less ambitious versions of Wechsler's approach demanded simply that the Court distinguish itself from a legislature by relying on "reason" rather than "fiat," ${ }^{, 404}$ but this approach also was doomed to failure. How helpful

399. Id.

400. See id. at 47 ("I should like to think that there is [a basis in neutral principles for holding that the Constitution demands that the claims for association should prevail], but 1 confess that I have not yet written the opinion. To write it is for me the challenge of the school-segregation cases.").

401. See, e.g., Louis H. Pollak, Racial Discrimination and Judicial Integrity: A Reply to Professor Wechsler, 108 U. PA. L. REV. 1, 24-31 (1959) (responding to Professor Wechsler's suggestion that "no supportable opinion could have been written in Brown - $\mathrm{r}$ at least that writing such an opinion is a 'challenge' not yet successfully met" by drafting "what he regards as an adequate opinion" from the perspective of "one who supports the judgment but confesses dissatisfaction with the opinion rendered").

402. Arthur Selwyn Miller responded to Wechsler's call for principled decisionmaking: "Not judges, but the professors of law, are those who should shoulder the task of constructing a body of legal principle and of developing a theory of explanation and justification." Miller, supra note 308, at 914. Given Miller's notion of the "living constitution," the recent pleas of "reasoned decision-making" seemed inappropriate to him: "The unlikelihood that interpretation leading to a novel result or the creation of new constitutional doctrine can be explained on the basis of existing law or principle would seem to be self-evident, both on the historical record and as a matter of logic." Id. at 894.

403. J. Skelly Wright, The Role of the Supreme Court in a Democratic Society-Judicial Activism or Restraint?, 54 CORNELL L. REV. 1, 3, 12 (1968); see also CURTIS, supra note 48, at 333-34; Bemard, supra note 104, at 266-71 (justifying judicial preference of First Amendment liberties).

404. Hart, supra note 43, at 99; see also Shapiro, supra note 308, at 591-92, 603 ("The call for neutral principles in its mildest form is a plea for reasoned elaboration rather than ipse dixits in Supreme Court opinions.... The judge should not be swayed by what the consequences of his decision will be. He must content himself with the reasonable application of general principles to particular situations.... If the Court is to be successful as a political actor, it must have the authority and public acceptance which the principled, reasoned opinion brings ...."); Bickel, Warren Court, supra note 197, at 31, 130-31 ("The Court must be able to demonstrate by reasoned argument why it thought the action right or necessary.... An action for which there is no intellectually coherent explanation may be tolerable ... but it is for the political institutions to take, not for the Court."). For a general discussion, see DUXBURY, supra note 190, at 267-78. 
was it simply to tell the Court to write better-reasoned decisions? An example of the disease was found in the Court's overreliance on summary per curiam decisions, which-critics maintained-the Court was using to decide cases that were far more complex than per curiam resolution suggested ${ }^{405}$ But criticism of judicial craft went well beyond that. ${ }^{406}$ The Court was deciding too much in some cases, not giving enough guidance in others. Although these arguments were couched as solutions to the countermajoritarian problem, ${ }^{407}$ and rested in a desire to separate law

405. WECHSLER, supra note 190, at 28 (indicating that per curiam decisions "make[] it quite impossible to speak of principled determinations or the statement and evaluation of judicial reasons, since the Court has not disclosed the grounds on which its judgments rest"); Emest J. Brown, The Supreme Court: 1957 Term-Foreword: Process of Law, 72 HARV. L. REV. 77, 94 (1958) (" $[\mathrm{I}] \mathrm{f}$ the Court exercises its discretionary jurisdiction to deal with issues of national significance, almost by definition those issues warrant, if they do not require, more than summary consideration."); Hart, supra note 43, at 89 n.13 (noting that the increase in the Court's use of per curiam decisions suggested that the Court viewed the right of appeal as excluding the right to have a case considered upon plenary briefs); Sacks, supra note 137, at 103 (noting that the number of summary per curiam opinions used by the Court "suggest[s] some ground for questioning whether the Court is giving sufficient attention to the need for explanation"); Note, Supreme Court Per Curiam Practice: A Critique, 69 HARV. L. REV. 707, 722-23 (1956) (noting that the widespread use of per curiam memorandums by the Court has given rise to a number of problems, including the lower courts' uncertainty as to the scope and effect of such decisions). Even Louis Pollak, most famous for his disagreement with Wechsler, agreed on this point. See Pollak, supra note 401, at 4-5. Similarly, Bickel and Wellington wrote:

[T]he less an opinion says, the less there may be in it for critics of the Court to seize upon for their own purpose, and one wonders whether it is not for this reason also that opinions have, of late, often said very little and have carried an air of assertion, as opposed to one of deliberation and rational choice.

... This is not to say that the per curiam orders were wrong. Nor is it to say that they could not be founded in reason, only that the Court made no effort to do so.

Bickel \& Wellington, supra note 364, at 3-4.

406. See SWISHER, supra note 321 , at $185-86$ (noting that "[i]f we become more and more disillusioned with principle and more and more convinced that nothing counts but power, whether physical or political or both, then we may expect the judiciary, again perhaps belatedly but nevertheless inevitably, to reflect the dominant sentiment, a sentiment that will stand in the way of the building of a body of law with a stable ethical core and with manifestations in all walks of life"); Griswold, supra note 155, at 92,94 ("[ $[\mathrm{l}] \mathrm{t}$ is one thing to act according to one's personal predilections or choice, and a wholly different thing to come to one's own best conclusion in the light of his understanding of the law as it has been established.... When decisions are too much result-oriented, the law and the public are not well served."); Louis Henkin, The Supreme Court, 1967 Term-Foreword: On Drawing Lines, 82 HARV. L. REV. 63, 65 (1968) (describing the Court's latest campaign as "mopping up" and "withdrawing from too-advanced positions"); Jerold H. Israel, Gideon v. Wainwright: The "Art" of Overruling, 1963 SUP. CT. REv. 211, 215 (noting that "overnuling a past decision raises some basic questions concerning judicial craftsmanship"); Bork, supra note 210, at 138 (quoting Columbia Professor Milton Handler, who stated that "[e]minent scholars from many fields have commented upon [the Supreme Court's] tendency toward overgeneralization, the disrespect for precedent, even those of recent vintage, the needless obscurity of opinions, the discouraging lack of candor, the disdain for the fact-finding of the lower courts, the tortured reading of statutes, and the seeming absence of neutrality and objectivity").

407. KURLAND, supra note 175 , at 182 ("To the extent ... that the Court's lawmaking is not justified by well-reasoned opinions, it is indulging in a privilege that belongs more to the legislature than to an appellate court."); see also FELDMAN, supra note 288, at 142 ("According to legal process, the requirements of reasoned elaboration meaningfully constrain judges in ways that executive officers, legislators, and administrators are not constrained. Reasoned elaboration 
(reason and principle) from politics (passion), all too often they read as broadsides at the Court's capabilities, reflecting the struggle for academic supremacy discussed earlier. "Some of its major opinions have been patently disingenuous. It has distinguished precedents on the flimsiest of grounds and frequently ignored those that it would not bother to distinguish." ${ }^{\circ 08}$ And it did not matter, argued Bickel, "one way or another" whether the Warren Court was any worse than other Courts, "for intellectual incoherence is not excusable and is no more tolerable because it has occurred before." ${ }^{, 409}$ One problem, the critics argued, was that the Court was simply overburdened with work, ${ }^{410}$ and thus could not hope to hand down persuasive and well-reasoned decisions. ${ }^{411}$

specifies the conditions or processes that engender the rule of law in a democracy, and those processes provide an objective foundation for neutral and apolitical judicial decision making."); KALMAN, supra note 2, at 20 ("Legal process theory sought to explain "how respect for procedure and principled decision making might lead judges to outcomes that conform to institutional and democratic norms ... develop a process explanation of law and adjudication that would achieve social purposes through the institutional settlement of disputes ... [and defend] the view that right answers in legal decision making could be developed from a conceptual understanding of the institutional functions and competency of different governmental agencies of the legal system." (quoting Justice Frankfurter)).

408. KURLAND, supra note 175 , at xxii.

409. BICKFL, supra note 265, at 47. For more broadsides, see supra notes 363-366.

410. See Robert H. JACKSON, THE SUPREME COURT IN THE AMERICAN SYSTEM OF GOVERNMENT 14-15 (1955) (discussing the lack of time devoted by Justices to the deliberation of cases); Griswold, supra note 155, at 84 ("The volume of the work of the Court is staggering. When one adds to that the factual complexity, the intellectual and legal intricacy of many of the questions, the public importance of the problems, and the difficulties inherent in reaching mutual understanding in any group of nine men, the burden seems to be insupportable, and to be a fair explanation of the source of some of the problems that some thoughtful persons have found in the work of the Court in recent years."); Henkin, supra note 406, at 64 ("That the [Warren] Court is willing, even eager to right as many wrongs as it can leads it to take cases which earlier courts would have let lie. Having taken them, it cannot bring itself to reach unsympathetic results, but reaching happy results may not be possible without major doctrinal reconstruction. To avoid that, the Court may fall into distinctions which cannot withstand close scrutiny."); Jerome Cohen, Book Review, 67 YALE L.J. 169, 172 (1957) (expressing the belief that the contemporary Court took "too many cases to permit adequate reflection"). At one point the Justices even went public on this subject. In an address at Cornell University, Justice Douglas denied that the Court faced a workload problem and stated that he had ample time to reflect on his work. See William O. Douglas, The Supreme Court and Its Case Load, 45 CoRNELL L.Q. 401 (1960) (discussing the "myth" that the Court is overworked). The next day, in an address before The Yale Law Journal, Justice Potter Stewart responded: "[T] he caseload of the court is demonstrably a heavy one.... This workload means, I am sorry to say, that there simply is not so much time as ideally there should be for the reflective deliberation so essential to the judicial process." Richard Eder, Stewart Differs on Court Burden, N.Y. TimEs, Apr. 10, 1960, at 4.

411. See Hart, supra note 43 (concluding that the number of cases to be decided by full opinion of the Court ought to be materially decreased to allow for adequate time for reasoned collective deliberation); see also Griswold, supra note 155, at 85-86 (agreeing with Hart on the workload debate and explaining that "[ $\mathrm{t}]$ here is only so much time in the day, and as the volume of work increases the opportunity for reflective deliberation necessarily decreases"). But see Arnold, supra note 365, at 1313-14 (disagreeing with Hart's position and rejecting the utility and existence of any collective thought in deciding cases). 
As each criticism of the Court proved incapable of its task, the ultimate solution offered most frequently to the countermajoritarian problem was simply "restraint." 412 If no acceptable guidelines for decision were available, then the Court was best advised to stay its hand. ${ }^{413}$ If it was impossible to define a judicial role, or to avoid one that was political, then perhaps the judges would do well simply to defer to the majority. ${ }^{414}$ Advocates of restraint claimed the Warren Court was being unacceptably "activist," rushing in to decide cases that did not require decision. ${ }^{415}$ This academic debate over activism and restraint was the one that revealed itself most publicly during the late 1950 s and 1960 s, rehearsed regularly as academics hit the opinion pages of modern culture. ${ }^{416}$

The problem was that most of these proposed solutions-and in particular the argument for restraint-were almost meaningless as a guide to decision. If the Court would slow down, and stay its hand more often, then undoubtedly less would be decided ${ }^{417}$ But this still said nothing about

412. See, e.g., MASON, supra note 301, at 167 (noting that Stone "urged restraint not because preference should not enter law, but precisely because it inevitably did"); Sutherland, supra note 228 , at 40 ("The Court . . . has wisely created for itself canons of self-limitation, lest it be asked or be inclined to attempt too much ...."); Kilpatrick, supra note 58, at 795 (noting that a code of self-restraint depends in part on the notion that "ours is a government not of men, but of law"); Methvin, Is the Supreme Court Really Supreme?, supra note 261, at 83 (comparing the Holmesian philosophy of restraint, in which "[a] judge should declare a legislative act unconstitutional only when he is certain that reasonable men could not disagree," with the Warren Court's activist philosophy, in which judges are the "modem interpreters of the values expressed in our living Constitution").

413. See Catterall, supra note 150 , at 832 ("The meaning of judicial self-restraint is that the judge will successfully restrain himself from putting his own convictions ahead of the law.").

414. McCleskey, supra note 210 , at 365 (noting that judicial restraint acknowledges the undemocratic character of judicial review and cautioning judges to "exercise restraint when faced with opportunities to judge policy decisions of elected officials"); Bork, supra note 210, at 141 (" $[R]$ estraint grows out of a theory of the division of labor or competence in government and defines not only the occasions upon which the Supreme Court should defer to the will of representative institutions but also the occasions for, and the manner of, judicial intervention.").

415. Catterall, supra note 150 , at $832-33$ (asserting that a lack of judicial restraint leads to judicial despotism, such as that exemplified in the Brown decision); Bork, supra note 210, at 168 ("Restraint entails not so much a reduced as a different role for the Court, one better suited to a democratic society than the role now played by the Warren Court."); Kilpatrick, supra note 58, at 794-95 ("The record of the Warren years is a record of judicial activism without parallel in the Court's long history. It is a trail of abuses, usurpations and invasions of power.").

416. For commentary on the debate between judicial activism and judicial restraint, see BLACK, supra note 1, at 88 ("Whenever the possibility arises that the Supreme Court might act with decisiveness to implement any of the guarantees written into the Constitution, [judicial restraint] is wheeled again into the breach and made to serve yet once more."); RODELL, supra note 104, at 121 (noting that self-restraint is self-defeating and circular: "Let us not use our power lest we lose our power. But power let go by default might as well be lost."); Miller, supra note 308, at 911 ("A quietistic role for the Court will help neither itself nor the American people. The 'passive virtues' belong to a passive age - not to the turbulence of the modern era."); and Wright, supra note 403, at 27 (discussing the major debate between advocates of judicial restraint and judicial activism).

417. This, the critics undoubtedly hoped, would lessen the level of controversy surrounding the Court. See WECHSLER, supra note 190, at 15 ("[M] $[\mathrm{Mch}$ would be gained if the governing 
which cases warranted the exercise of judicial review. The call for restraint gave no clue, standing alone, as to which controversies justified Supreme Court intervention, and which did not. "[C]onsiderations of judgment and 'self-restraint' hardly constitute a theory of judicial action. . . . They tell us when it may be wise for the Court not to act. But they tell us next to nothing about when the Court should act or what it should do when it does. ${ }^{, 418}$ Indeed, even as he acknowledged that history had provided no guide to Justices or commentators as to what these cases should be, Robert McCloskey nonetheless made clear that the Court had never acted with the "modesty" the restraint commentators demanded of it, and was unlikely to do so.

Whatever the theoretical merits of [the suggestion of self-restraint] the short answer is that it asks the Court to take leave of its heritage. The Court of history has never assessed itself so modestly, and there is not much reason to expect that the Court of the future will deliberately choose such a policy of renunciation. ${ }^{419}$

The argument for restraint simply failed to cut it, "especially since," as one commentator pointed out, "each of the critics had his own preferred areas of judicial activism."

With nowhere else to go, the argument for judicial restraint ultimately found its way back into the countermajoritarian problem. As Clifton McCleskey put it, judicial restraint "acknowledges the undemocratic

statutes could be revised to play a larger part in the delineation of the causes that make rightful call upon the time and energy of the Supreme Court."). As many poignantly observed, however, it was difficult to argue that whatever controversy had been stirred up by Brown would have been less intense had the Court decided the case the other way. On this point, Anthony Lewis wrote:

The fact that the opinion in the Brown decision was difficult to write, or that the desired unanimity on the Court was hard to obtain behind a particular form of words, or that all the implications were not foreseen none of these shows that the decision should have gone the other way, or indeed that a contrary opinion would have been easier to write or more persuasive.

Lewis, supra note 188 , at 331 .

418. Rostow, supra note 298 , at xxxiii-xxxiv; see also Miller, supra note 308 , at 884 ("While a number of observers have asserted that the Constitution is an evolving document, we have never been told much more than that. The concept of the 'living Constitution' has never been explained in detail so as to indicate how far it goes and what it means."); Silver, supra note 276, at 377 (observing disagreement among critics of the Warren Court as to the "Court's mandate").

419. MCCLOSKEY, supra note 298, at 228; see also MCCLOSKEY, supra note 63, at 328 ("Like most of the nation the members of the 'Roosevelt Court' were conceptually prepared only to declare what the judicial branch should not do; what it should do and why had not been thought out."); id. ("[T] he past offered little useful guidance as to how the new concern for civil rights should be specifically implemented.").

420. Silver, supra note 276, at 376; see also RODELL, supra note 104, at 19-20 ("So long as the passivists, the judicial-self-denial boys, the alleged advocates of non-interference in legislative or executive decisions, refuse to go so far as to say that the Court has no power to interfere, refuse to urge abdication by the Justices of the role that Marshall won for them, the Court will continue to interfere, and continue to govern, merely by imminent omnipresence of that power."). 
character of judicial review, and for that reason cautions judges to exercise great self-restraint when confronted with opportunities to sit in judgment on the policy decisions of elected officials. ${ }^{, 221}$ Or, as Robert Bork explained it, "Restraint grows out of a theory of the division of labor or competence in government and defines not only the occasions upon which the Supreme Court should defer to the will of representative institutions but also the occasions for, and the manner of, judicial intervention." ${ }^{, 422}$

\section{The Liberal Tension}

It is thus possible to see how mid-century scholars perceived a countermajoritarian problem, but - as we have seen-it was emphatically not the same problem experienced during the Progressive Era. Progressives leveled a critique of judicial review. By mid-century and beyond, the scholar-descendants of the Progressive Era critics were looking not to critique, but to justify the exercise of judicial review.

Mid-century scholars approved of at least some of the Warren Court's work but for historical reasons were hard-pressed to explain why. They felt the need to justify judicial review within the confines of the democratic paradigm, and thus an insoluble tension was born. As Laura Kalman has explained, "[F]or the legal liberals who loved the Warren Court's results, if not its reasoning, and who dominated the law professorate between the New Deal and the Vietnam War, the Warren Court starkly posed 'the countermajoritarian difficulty,' the dilemma of legitimating an appointed judiciary in a democracy. ${ }^{, 423}$

Nowhere was the problem more apparent than in Bickel's writing. Bickel's own theory of the Court's special role was itself "ultimately amorphous. ${ }^{1424}$ Bickel argued that the Court's resort was to principle, but he also insisted-recognizing full well the importance of popular supportthat the Court should simply duck the question at times when a decision would be controversial. As Gerald Gunther famously pointed out, Bickel's notion of "passive virtues" meant that Bickel was for " $100 \%$ insistence on principle, $20 \%$ of the time. ${ }^{, 425}$ Moreover, Bickel would lambast the Court for deciding on broad grounds, rather than approaching matters slowly, on a

421. McCleskey, supra note 210 , at 365 .

422. Bork, supra note 210, at 141; see also Lamb, supra note 345, at 9-10 ("The first premise typically drawn upon to support restraint involves the assertion that judicial policymaking conflicts with the very essence of a democratic society. Judicial policymaking is said to defeat the purposes intended by the people's elected representatives and therefore to run counter to popular sentiment.").

423. KALMAN, supra note 2, at 6 .

424. Purcell, supra note 286, at 541.

425. Gerald Gunther, The Subtle Vices of the "Passive Virtues"-a Comment on Principle and Expediency in Judicial Review, 64 COLUM. L. REV. 1, 3 (1964). 
case-by-case basis. ${ }^{426}$ "That was surely sage common law advice, but if it were followed very few cases would contain truly neutral principles., ${ }^{, 427}$

No surprise then, that when it came to principle, Bickel was not always clear in advancing one. Take Miranda, of which he approved. "The Court is, and ought to be, more apt to dig in its heels on issues of criminal procedure than on matters of more substantive policy . ..., ${ }^{, 428}$ But why was this so? Why was Miranda not the very paradigm of a countermajoritarian decision Bickel deplored? ${ }^{429}$ Ultimately, Bickel could not tell us. At least Bickel was candid in admitting that one might question the "insistence on principle" and reason as "reasonable men may differ about the conclusions to be drawn from the most rigorous attempt at analysis itself.",430

"It is no wonder that 'tension' was the central metaphor of the book." Bickel's own ideas were profoundly in tension with one another. As a matter of pure descriptive reality, Bickel's "counter-majoritarian difficulty" missed the mark in many ways. The fact that it captivated him so, nonetheless suggests a far deeper internal conflict.

In some sense this is because Bickel stood at the cusp, between generations, and even between institutions. Bickel was a disciple of, and deeply devoted to, Frankfurter. ${ }^{432}$ He had clerked for Frankfurter and been promoted by him. ${ }^{433}$ When Frankfurter passed away, Bickel eulogized the Justice in the New Republic, deeming him among the greatest Justices ever, "[a]nd above all there never was such a friend." ${ }^{434}$ And Bickel was a

426. BICKEL, supra note 265 , at $95-96$.

427. Purcell, supra note 286, at 551 .

428. BICKEL, supra note 265, at 93-94.

429. As Skelly Wright would observe, "[W]e may stop to wonder why Bickel chose only to attack the school desegregation and reapportionment cases on the ground of impending obsolescence, while ignoring the one body of decisions which most clearly are at odds with a discernible trend of opinions and events: the criminal procedure cases." Wright, supra note 276, at 803.

430. BICKEL, supra note 265 , at 97.

431. Purcell, supra note 286, at 543. Purcell identifies several deep intellectual problems with Bickel's own theory, not necessarily touched on above.

432. See $i d$. at 527-28 ("Bickel came to see the Justice as embodying a "splendid and a rare career' which had been pursued 'without compromise of principle, indeed with an utter inability to so much as modulate moral and intellectual integrity.'"); see also id. at 528-29 (noting that in Bickel's first book, The Unpublished Opinions of Mr. Justice Brandeis, he "acknowledged Frankfurter as an 'inspiration' .... 'My intellectual debt to him is immense.'").

433. Purcell describes Frankfurter's efforts to support Bickel,

first by encouraging Bickel's participation with professor Paul A. Freund, himself an ex-clerk of Justice Brandeis and an intimate friend of Frankfurter's, in the scholarly mining of the rich Brandeis papers, and second by trying as forcefully as possible within the bounds of discretion to secure for Bickel a permanent position on the Harvard Law School faculty in 1956.

Purcell, supra note 286 , at 528.

434. Alexander M. Bickel, Felix Frankfurter (1882-1965), NEW REPUBLIC, Mar. 6, 1965, at 7; see also Purcell, supra note 286, at 528 (describing the relationship between the two). The coincidence of views between Bickel and Frankfurter is particularly stunning. Witness again the inconsistency of Bickel's countermajoritarian criticism when it came to reapportionment and 
Harvard man, having studied in the heart of the Legal Process school. ${ }^{435}$ At the same time, Harvard passed on Bickel when it came time to teach, and he ended up at Yale. Laura Kalman quotes from several pieces of Bickel's correspondence that emphasize his place betwixt and between these two institutions. Bickel wrote to Rostow of "the unpardonable sin of constructing a camp and taking anyone into it. ${ }^{, 436} \mathrm{He}$ wrote Louis Jaffe:

I for my part deplore ... the expression "you people." There is no such animal. At least I am no such animal. Some of my colleagues here address me as you people, meaning me and Herbert Wechsler and you and Henry Hart and god knows what other devils. And you address me as you people meaning at least a little bit me and activist judge David Bazelon .... Well, I am none of them fellows, nor any of you fellows. ${ }^{437}$

And he wrote Peter Strauss, a Brennan clerk, "Why is it you fellows don't recognize that I am on your side? Probably because you cannot rid yourselves of the presumption that I would be unlikely to be on your side. ${ }^{, 438}$

But, more deeply and importantly, Bickel was conflicted on philosophical grounds. When it came down to fundamentals, Bickel was ready to part ways with Frankfurter (and Hand), precisely because he was tom in another direction: "I am persuaded the function of judicial review under the Fourteenth Amendment and under the Bill of Rights is necessary in our society," he wrote the Justice. "I am so persuaded on principle., ${ }^{, 439}$ It was for this reason that the later Bickel continues to puzzle scholars. As

criminal procedure cases. Both of these make more sense when seen through the lens of Frankfurter. Nothing may have upset Frankfurter more than the reapportionment decisions, and the overruling of his Colgrove opinion in Baker v. Carr. See HIRSCH, supra note 278, at 197-98 ("[I]n Baker v. Carr ... Frankfurter dissented; he reiterated, for nearly the last time, that social change must come not through the courts but through 'an aroused popular conscience that sears the conscience of the people's elected representatives.'"). And for all his countermajoritarian rhetoric, Frankfurter clearly had a soft spot for the rights of those accused of crimes. See UROFSKY, supra note 343, at 23 (describing Frankfurter's "near-religious belief in the integrity of the criminal justice system," which led him to draft a controversial article defending Sacco and Vanzetti in 1927); id. at 125 (noting that although Frankfurter did not abandon his position in Dennis, he "described the communist menace as puny and deplored the witch-hunt atmosphere of the McCarthy years").

435. KALMAN, supra note 2, at 30 (noting that, like Bickel, "most process theorists had been trained at Harvard").

436. Id. at $264 \mathrm{n} .48$ (quoting Letter from Bickel to Eugene Rostow (Nov. 8, 1961) (Bickel Papers, Box 9, Folder 166) (on file with author)).

437. Id. (quoting Letter from Bickel to Louis Jaffe (Sept. 30, 1965) (Bickel Papers, Box 9, Folder 167) (on file with author)).

438. Id. (quoting Letter from Bickel to Peter Strauss (Mar. 9, 1966) (Bickel Papers, Box 9, Folder 180) (on file with author)).

439. Purcell, supra note 286, at 533-34 (quoting Letter from Bickel to Frankfurter (July 31, 1958) (Frankfurter Papers, Box 24, Folder 357)). 
Anthony Lewis explained in his foreword to The Supreme Court and the Idea of Progress, "Professor Bickel was in the tradition of those who have doubted the perfect wisdom of judges, but his situation differed in one vital respect from that of the great critics of the earlier years of this century." Whereas the earlier critics challenged judges who took conservative positions on issues of economic rights, "Professor Bickel criticized a Supreme Court that took enlightened positions on issues of race and civil liberties-undoubtedly the most 'liberal' Court in our history. And so, inevitably, he puzzled or provoked much of his natural audience." ${ }^{, 440}$

It is precisely in this shift from a conservative to a liberal Court that Bickel, and with him much of the following generation of liberal legal scholars, got caught. It was natural for Progressive Era critics to criticize judicial review as undemocratic and leave it at that. Most of what the old Court was doing was unacceptable to them. But a Court that eschewed regulation of the economy and focused on equality and individual liberty, that was a different matter. It was more difficult for liberal scholars to consign that Court to a role of blind deference to majoritarian decisionmaking.

Yet, these mid-century critics were still stuck in the paradigm of "democratic faith" that they had inherited. Even if the Court was doing things that might be "beneficial," still, "doubts are rooted in the democratic faith, which holds that society at large ought to participate in the venture of governing itself., ${ }^{, 41}$ No wonder then that Bickel concluded his obituary of Frankfurter, calling him an "'implacable democrat,' secure in his faith." "442

The writings of liberals, Court critics and defenders alike, focused (one might say fixated) on this inherent tension of liberal democracy. Kurland, discussing the "paradox implicit in constitutional democracy," quoted Charles Mcllwain: "We live under a written constitution which classifies some things under jurisdiction, as legal fundamentals, and thus puts them under the protection of courts, while it leaves other matters to the free discretion of the organs of positive government it has created." ${ }^{, 43}$ In The Least Dangerous Branch, moving from supposed description to theory, Bickel observed, "Democratic government under law - the slogan pulls in two opposed directions ...."444 And this tension was at the heart and frame of Robert McCloskey's classic work (published in 1960) The American Supreme Court:

440. Anthony Lewis, Foreword to BICKEL, supra note 265 , at viii; see, e.g., Lewis, supra note 188, at 320-21, 330-31 (defending the Court's holdings in cases such as Brown against the criticism of Bickel and others).

441. BICKEL, supra note 289 , at 105 .

442. Bickel, supra note 434, at 7 (quoting Alvin Johnson's similar remark about Brandeis).

443. KURLAND, supra note 175 , at 8-9.

444. BiCKEL, supra note 16 , at 27. 
The bifurcation of the two values in the American mind impellingly suggested that the functions should be similarly separated. And the devotion of Americans to both popular sovereignty and fundamental law insured public support for the institution that represented each of them. This dualism... helps account for a good deal that seems baffling in later history .... 45

Many liberals seemed genuinely torn by this apparent choice between democratic principles and judicial results. ${ }^{446}$ Perhaps the most famous example of this was Herbert Wechsler's public denunciation of the Brown Court, not only for failing to enunciate a neutral principle underlying the opinion, but because Wechsler himself could not identify one. This, despite Wechsler's personal belief that the decision and others like it "have the best chance of making an enduring contribution to the quality of our society of any that I know in recent years." ${ }^{\text {"447 }}$ Thus, Brown stood "for one of my persuasion" as "stir[ring] the deepest conflict I experience in testing the thesis I propose." $"$ Wechsler was hardly alone: Philip Kurland advanced withering attacks on the Court, all the while approving its role "to protect the individual against the Leviathan of government and to protect minorities against oppression by majorities." ${ }^{, 49}$ Kurland would "applaud" the result in Cooper v. Aaron ${ }^{450}$ while challenging its reasoning and offering no clear substitute. ${ }^{451}$ And, Edward Purcell explains how

Warren Court liberal activism distressed Hart-indeed, perplexed him deeply - not merely because he was unable to reconcile its decisions with his own professional standards. The Warren Court confounded him because it embodied, albeit in a form he found unsatisfactory, many of his fundamental values and ideals: judicial creativity, protection of individual liberty, institutional recognition of moral principles. ${ }^{452}$

The problem for latter-day (as opposed to Progressive Era) liberals, of course, was that they professed belief both in the results of the Warren Court and in the democratic creed that formed the basis for attacking

445. MCCloSKEY, supra note 63, at 13-14; see also id. at 17, 18 .

446. Mark Tushnet and Timothy Lynch capture this ambivalence in their article on the Harvard Forewords. In particular, they discuss how Philip Kurland and Archibald Cox were both profoundly tom by their adherence to Legal Process theory and their approval of Warren Court results. See Tushnet \& Lynch, supra note 286, at 482 (discussing Kurland); id. at 82-83 (discussing Cox).

447. WECHSLER, supra note 190 , at 37.

448. Id. at 43.

449. Kurland, supra note 276 , at 45.

450. 358 U.S. 1 (1958).

451. Id. at 30-31.

452. PURCELL, supra note 334, at 257. 
judicial review. ${ }^{453}$ Some of this was inherent in the work the Warren Court itself was doing; because "the Supreme Court under Warren ... was under attack not for its lack of democracy, but for its democratic zeal," the internal tension was inevitable. ${ }^{454}$ But even when the Court arguably was rendering countermajoritarian decisions, such as striking down laws restricting the rights of Communists, liberals agreed with the results. ${ }^{455}$ In these cases, both halves of the liberal faith were put to the test: the longstanding Progressive creed in noninterference with democratic legislative results, and the new-found liberal belief in individual liberty. ${ }^{456}$

That this was the liberals' own special problem was evident in part from the fact that liberal defenses of the countermajoritarian problem were written at a time when no one in particular in the academic sphere was leveling the countermajoritarian criticism as a basis for judicial inaction. Assuredly, Learned Hand's challenge to judicial review rested on a countermajoritarian argument, ${ }^{457}$ but his skepticism regarding the propriety of judicial review was almost uniformly rejected in the academic world. ${ }^{458}$ Alternatively, those such as Herbert Wechsler and Henry Hart who vehemently opposed Warren Court activism barely mentioned the

453. Kalman captured this point:

The process theory critique, which grew out of legal realism, hurt the legal realism associated with the Warren Court, not legal liberalism. It did not demonstrate dissatisfaction with the Warren Court's results, for almost all law professors at the time were liberal in their politics. ... Wechsler picked the cases he criticized in his Holmes Lecture because he admired their outcomes.

KALMAN, supra note 2, at 47.

454. White, supra note 144 , at $196-97$.

455. See Deutsch, supra note 185 , at 181 ("Wechsler's point, then, is that the constitutional protection afforded by Black to Negroes and Communists, whom we do wish to protect, makes it impossible to deny those protections to such labor racketeers and racial agitators, whom we ought not to protect." (emphasis added)); see also KALMAN, supra note 2, at 47 (observing that liberals supported the substance of the Court's decisions).

456. Commager discussed the tension between two "fundamentally contradictory" institutions:

[F]irst the institutionalization of the principle that men can alter, abolish, and institute governments, can, in short, make government conform to their will. But over against this we have the institutionalization of the principle that governments are limited-that there are things that not even a majority may require government to do because they are outside the jurisdiction of any government.

COMMAGER, supra note 48 , at $7-8$.

457. See HAND, supra note 122 , at 73 ("' $[\mathrm{I}] \mathrm{t}$ certainly does not accord with the underlying presuppositions of popular government to vest in a chamber, unaccountable to anyone but itself, the power to suppress social experiments which it does not approve.").

458. For a rejection of Hand's views, see Addison Mueller \& Murray L. Schwartz, The Principle of Neutral Principles, 7 UCLA L. REV. 571, 588 (1960) ("The nine men who make up our Supreme Court are those who have been so chosen under our system of government. They must, therefore, give full scope to the exercise of their collective judgment as to the meaning and the application of constitutional guarantees, if those guarantees are to retain vitality."). See also WECHSLER, supra note 190, at 34, 39 ("[I]t misconceives the problem of the Court to state it as the question of the proper measure of judicial self-restraint.... [F]or anyone who finds the judicial power anchored in the Constitution, there is no such escape from the judicial obligation; the duty cannot be attenuated in this way."). 
countermajoritarian difficulty, if at all. ${ }^{459}$ Extended discussion of the countermajoritarian difficulty was found not in challenges to judicial review, but in defense of it, most notably in the writings of Eugene Rostow and Charles Black. ${ }^{460}$ Indeed, this was the very bulk of their scholarship, trying to respond to the countermajoritarian problem. ${ }^{461}$ The most extensive discussion of the countermajoritarian difficulty in a negative light was Bickel's, but his book also (it seems important to keep reminding oneself) was a defense of judicial review, not a challenge to it. ${ }^{462}$

Indeed, having observed almost 200 years of conservative defense of the Court as an anti-majoritarian institution, it is almost extraordinary to hear the countermajoritarian criticism appear on relatively conservative academic lips, as it does for the first time in 1968. In that year a professor named Robert Bork authored an article in Fortune. ${ }^{463}$ His conservative

459. Herbert Wechsler, Comment, in GOVERNMENT UNDER LAW 137 (1955) (speaking out as a supporter of judicial review and responding in passing to the problem of the Court as an "embodiment" of the people). Hart does not mention the countermajoritarian problem.

460. On the eve of Brown, Rostow responded to the charge that judicial review is undemocratic:

[Judicial review as a means] of policing the Constitution is not undemocratic. True, it employs appointed officials, to whom large powers are irrevocably delegated. But democracies need not elect all the officers who exercise crucial authority in the name of voters. . . . The task of democracy is not to have the people vote directly on every issue, but to assure their ultimate responsibility for the acts of their representatives, elected or appointed.... Given the possibility of constitutional amendment, there is nothing undemocratic in having responsible and independent judges act as important constitutional mediators.

... [T] effect of not inhibiting but of releasing and encouraging the dominantly democratic forces of American life.

Rostow, supra note 129, at 197, 210.

In a later article, Rostow again spoke out against Hand's perception of the undemocratic nature of judicial review: "The dominance of the popular will through the mechanisms of our system of government is achieved in large part by having the courts enforce limitations on the power of elected officials, in the name of constitutional provisions which only the people can alter by amendment." Rostow, supra note 187, at 590. Professor Charles Black similarly defended judicial review as a legitimate institution in a democracy justified on the basis that the people have given their consent to such a system and that "Congress and the President and the people could if they wanted to, dismantle the institution ... by entirely lawful means." BLACK, supra note 1, at 178. According to Black:

What we have to decide, then, is not whether it is "undemocratic" for the practice of judicial review to be imposed on the people against their will, but whether it is "undemocratic" for the people themselves, through their own Constitution and laws, to make the decision... that they want a body such as the Court to do the job of Id.

Constitutional umpiring.

461. See supra note 446.

462. BICKEL, supra note 16, at 24 ("The search [for a theory of judicial review] must be for a function which might (indeed, must) involve the making of policy, yet which differs from the legislative and executive functions; which is particularly suited to the capabilities of the courts ....").

463. Bork, supra note 210. 
credentials were somewhat in the balance; he seemed to agree with Griswold, but was quite critical of the Court in other ways. Nonetheless, what is most interesting is to hear an academic critic of the Warren Court express the countermajoritarian concern. But this was exactly Bork's concern: "What, after all, justifies a non-elected committee of lawyers in overriding the policies of the elected representatives of the people?"464

Perceptive observers at the time perceived the oddity of the countermajoritarian argument, and noticed its special character as a liberal problem. Eugene Rostow circled around the argument twice. He observed that liberal judges would have to exercise their power, despite the nondemocratic pedigree: "The judges cannot refuse to decide cases because they personally believe the United States would be a more democratic country without judicial review. ${ }^{, 465}$ And he pointed to the debate over whether "the Supreme Court in construing the Constitution makes it an oligarchic or aristocratic excrescence on our Constitution," observing that "[a]nxiety on this score has colored the temper in which some of our best judges have approached their work.",466 "Many," he concluded, "have found in this issue a paradox impossible to reconcile with their faith as democrats. ${ }^{467}$

But it was Skelly Wright, vehement defender of the Warren Court on the basis of its results, who saw clearly the problem liberals had worked themselves into. Realism had collapsed judicial and legal thinking: "This equation of legal and ordinary decisionmaking led the progenitors of the scholarly tradition to identify an apparent conflict with another root proposition of their creed: the overriding virtue of the democratic political process." ${ }^{468}$ "[T]he experience of the Warren Court...posed new problems. With primarily civil rights and liberties at issue, the heirs of the progressive realists professed their values led them to side with the Court against the legislature and executive. ${ }^{.469}$ Faced with this problem, Wright pointed out that Bickel himself had seen Justice Frankfurter try and fail to achieve a "rigorous general accord between judicial supremacy and democratic theory." ${ }^{470}$ "The leading commentators of the scholarly tradition have tried ever since to succeed where the Justice failed."471

464. Id. at 138 .

465. Rostow, supra note 129, at 213 .

466. Rostow, supra note 187 , at 575 .

467. Id. (emphasis added).

468. Wright, supra note 276, at 773-74 (emphasis added).

469. Id. at 774-75.

470. BICKEL, supra note 265 , at 34 (discussing Frankfurter).

471. Wright, supra note 276 , at 775 . 


\section{Needing the Court}

At the end, there is irony. Raised to believe judicial review was at odds with democracy, the mid-century scholars parroted their predecessors' words, even as they believed in at least some of what the Court was doing. Much as they complained about the Court, these scholars had come to see what it could accomplish, and many liked what they saw. ${ }^{472}$ But stuck in the Progressive tradition, the Court they needed was also one they believed necessarily acted contrary to popular will. As Philip Kurland explained, the Court "is politically irresponsible and must remain so if it would perform its primary function in today's harried society. That function, evolving at least since the days of Charles Evan Hughes, is to protect the individual against the Leviathan of government and to protect minorities against oppression by majorities."

Because they believed the Court necessarily acted contrary to popular sentiment, and yet they approved of its work, they also feared for the Court's safety. After all, there is another lesson they had learned from their fathers: that a countermajoritarian court was at risk. Those Progressives who challenged the Court early in the century saw their handiwork come to fruition in the Court-packing threat of 1937. And this, as much as anything, likely motivated their willingness to call for restraint even as some of them praised the Court. The Court-packing plan, seemingly an answer to Progressives' complaints about judicial review, nonetheless caused them profound consternation. Announcement of the plan had "strengthened Hand's persistent fear that activist judicial review would ultimately destroy the independence of the judiciary. ${ }^{, 474}$ Hand opposed the plan. Others in the scholarly tradition, such as Henry Hart, supported it at the time, ${ }^{475}$ but lived to change their views about the relative merits of legislative primacy and judicial review. ${ }^{476}$ Moreover, all of them lived through the last great attack on the Supreme Court, the jurisdiction-stripping measure offered in

472. See supra notes $447-455$ and accompanying text; see also BICKEL, supra note 265 , at 176 ("We wish [the Court] to endure ... because ... the Court discharges a much narrower, but still reasoned and principled, law-making function. ... Someone must do this."); MCCLOSKEY, supra note 63, at 366 ("The Supreme Court probably can play its modern, elevated governmental role in the foreseeable future. .. Whether it will is a question for another day."); Cox, supra note 267, at 829 (noting that the Court "must sometimes be the voice of the spirit, telling us what we are by reminding us of what we may be. . . [T] he power of the great constitutional decisions rests upon ... the Court's resulting ability, by expressing its perception, ultimately to command not merely a passive but a supportive consensus.").

473. KURLAND, supra note 175 , at 204.

474. Purcell, supra note 336 , at 914.

475. PURCELL, supra note 334, at 230-31.

476. Id. at 239-42; see also id. at 240 ("In the 1930s the young Progressive had depicted the courts as incompetent to formulate policy and Congress as expert; by the 1950 he portrayed the courts as refined instruments of reason and the legislature as the voice of ignorance and partisanship."). 
response to the Communist decisions. Thus it was Bickel-the very same Bickel who found himself philosophically different from Hand and Frankfurter as to the utility of judicial review itself-who would explain: "[G]overnment by the judiciary ... will not be tolerated. This way lies crises such as the Court-packing fight of 1937, in which the Court, if it persists, must ultimately be the loser."${ }^{, 477}$

\section{CONCLUSION}

There has been remarkably little curiosity in the legal academy about the genesis of our own fixation with the countermajoritarian problem. It is not even seen as a fixation. That likely is because academics view the intellectual problem with which they struggle as a timeless one. Thus, there simply is no basis for wondering what gave rise to it.

It should now be obvious that the countermajoritarian problem is neither timeless nor immutable. Rather, it is the product of a historically contingent set of circumstances. It is true that courts have been criticized throughout American history when they acted contrary to the will of the people. But this is not what occupies the legal academy, which frets over the countermajoritarian problem even when the broader public does not. Nor is most of the legal academy concerned with deeper questions regarding democratic theory and the role of constitutional courts in that theory. What has occupied the academy-at least until recently-is likely what occupied mid-century's judicial critics: a concern about the indeterminacy of law, and the legitimacy of judicial review even when they approve of it. These concerns have been wrapped in countermajoritarian language merely because it is familiar.

All of a sudden things are changing again. Frustrated that the Court has not taken academic direction as to how judicial power should be exercised, some academics today seem more willing to give up on judicial review, raising what must seem to today's anxious academics to be profound and pressing questions about the role that the Court plays in a society that calls itself a democracy. This sounds, one cannot help but note, remarkably like Progressive Era critics of the Court, and-as should now be apparent-is something quite different than what Bickel and his contemporaries were struggling with.

The questions being raised today are weighty and important ones. But we might approach these questions with greater humility if we developed an understanding of the times that we have been here before-and by the same token, the times that we have not. The subtle shifts occurring only underscore the need for academic work on judicial review that transcends in

477. BICKEL, supra note 16, at 93. 
prescription immediate political preference and moves in theory beyond aged rhetoric. This has not happened enough because we have failed to understand the historical contingency of the problem we call the "countermajoritarian difficulty."

It need not be this way. There are other directions that can be taken.

First, law professors might move themselves to study judicial review on more pragmatic terms, trying to assess how well it functions, and what it offers in the real world. There are scholars in other disciplines already engaged in this venture, and it might seem they have a comparative advantage. But a review of that scholarship reveals that the work of other disciplines, for all its methodological strength, often suffers from an insufficient understanding of law and the legal process. ${ }^{478}$ So, there is room for law professors to tackle important questions, and to assist others in doing so. For example, it is important to undertake to assess realistically whether judicial review is a net gain or loss for values we hold dear, be they economic growth and security, individual liberty, or equality. ${ }^{479}$ Stated differently, is judicial review worth it even when we deplore particular results?

Similarly, we might try to understand whether judicial review really is countermajoritarian, and how it interacts with public opinion. In order to answer this question we need to know the extent to which Supreme Court decisions actually do deviate from popular opinion, and on what issues, if any, this is most common. Deviation, of course, could be bad or good, depending upon the values being protected, and we have a remarkably unsophisticated grasp of this. We do not really know how much the public pays attention to the Supreme Court, what decisions are salient, what politicians can do to make them so, or if the Supreme Court pays any attention to public opinion or the views of the other branches. There is preliminary work on all these questions, but little of it involves legal academics, although they have much to add.

Second, legal academics might continue to do what they always have done, which essentially is to make normative arguments about the way law should be, and what judges should do, on the merits. What might be liberating is if those academics did so without the gift wrapping of the countermajoritarian problem. Current practice serves only to obscure that what is on offer is the author's own view, as opposed to a theoretical solution to a problem we have seen is intangible in any event. More explicit normativity might liberate scholars and improve the quality of the argument. Of course, it is possible that just as the countermajoritarian

478. See Friedman, supra note 32.

479. See Charles Cameron, Judicial Independence: How Can You Tell It When You See It? And, Who Cares?, in JUDICIAL INDEPENDENCE AT THE CROSSROADS: AN INTERDISCIPLINARY APPROACH (Stephen B. Burbank \& Barry Friedman eds., 2002). 
problem represented concern about the legitimacy of judicial review, so too scholars will worry about expressing normative views without the cover of solving deep-seated intellectual problems. But the risk is worth the reward, as those normative views were all that really existed anyway.

Third, it is important to understand the extent to which constitutional law inevitably is tightly enmeshed with politics. Who sits on the bench will matter. So too will the participants in the process that confirms the judges. And it will be important who staffs the other branches; whether they are willing to accede to judicial decisions or struggle with them, challenge them, or discipline a Court that renders them. Judicial review exists in politics, even if it is not of it, but our understanding of all this is woefully thin.

All of this underscores the following observation: Normativity as to the outcome of specific issues is valuable and poses no great problem, but normativity about judicial review itself does. If scholars are going to raise questions about judicial review itself, then it is important to get right whether judicial review is a net gain or loss for society. Getting it right means doing so not just for this time, and probably not just for the Supreme Court, but for all courts and all time. Not that there has to be a one-size-fitsall-times-and-courts answer, but the scholarship should at least be clear as to what is being addressed. Judicial review is practiced by appellate courts and trial courts, by state courts and federal courts, by international tribunals. These courts are chosen in different ways and exercise their powers differently. The rules governing judicial review in all contexts at all times will not be the same. ${ }^{480}$ If the problem is the Supreme Court, at this time, we should say so and why, drawing distinctions between positive exercises of judicial review and negative ones. We should not (necessarily) junk the entire venture, at least until we have determined-as the first project is designed to do-what it adds or detracts.

But even as to the Supreme Court alone, it does seem that, at some level, it just can't be that the right answer depends solely upon who is sitting behind the bench, and how the cases are being decided. There ought to be a perspective, an understanding of judicial review, an assessment of its worth, that transcends such temporal factors. This is not even to say that the understanding need be immutable. It just ought to rest on some sustained understanding of how judicial review actually operates, and what it accomplishes, over time. We don't have that understanding yet; we're not even close.

480. See, e.g., Helen Hershkoff, Positive Rights and State Constitutions: The Limits of Federal Rationality Review, 112 HARV. L. REV. 1131 (1999) (arguing that state court standards of review should differ from federal standards when applied to poverty clauses of state constitutions). 
We won't get close until we move beyond our simple-minded fixation with the countermajoritarian problem. Moving beyond it is important; doing so has not been easy. But that has been the point here. Our obsession is a product of historical contingency. We should now be able to see that. 
Imaged with the Permission of Yale Law Journal 